\title{
DIOGO MOYSES RODRIGUES
}

\section{O DIREITO HUMANO À COMUNICAÇÃO: IGUALDADE E LIBERDADE NO ESPAÇO PÚBLICO MEDIADO POR TECNOLOGIAS}

\author{
Dissertação de mestrado \\ Orientadora: Professora Dra. Maria Victoria de Mesquita Benevides
}

Faculdade de Direito da Universidade de São Paulo

São Paulo

2010 
DIOGO MOYSES RODRIGUES

\title{
O DIREITO HUMANO À COMUNICAÇÃO: IGUALDADE E LIBERDADE NO ESPAÇO PÚBLICO MEDIADO POR TECNOLOGIAS
}

\author{
Dissertação de mestrado apresentada à \\ Faculdade de Direito, na área de concentração \\ de Direitos Humanos, como requisito para a \\ obtenção de título de Mestre, sob orientação da \\ Profa. Titular Maria Victoria de Mesquita \\ Benevides
}

São Paulo

2010 


\section{DIOGO MOYSES RODRIGUES}

\section{O DIREITO HUMANO À COMUNICAÇÃO: IGUALDADE E LIBERDADE NO ESPAÇO PÚBLICO MEDIADO POR TECNOLOGIAS}

Dissertação de mestrado apresentada à Faculdade de Direito, na área de concentração de Direitos Humanos, como requisito para a obtenção de título de Mestre, sob orientação da Profa. Titular Maria Victoria de Mesquita Benevides

Aprovada em:

Banca Examinadora

Prof. Dr.

Instituição

Assinatura

Prof. Dr.

Instituição

Assinatura

Prof. Dr.

Instituição

Assinatura 
À Anna Luiza e Iara, luzes da minha vida. 
"No momento em que a informação e a comunicação, dimensões ancestrais de qualquer experiência humana e social, passam a constituir indústrias e mercados, é preciso desenvolver urgentemente conhecimentos e teorias para relativizar o tecnicismo e o economismo, e preservar as dimensões de emancipações que, desde o século XVI, na Europa, estiveram na origem das batalhas pela liberdade de informação e de comunicação. [...] não haverá democracia no plano mundial sem uma reflexão teórica sobre os desafios políticos, culturais, técnicos, antropológicos e sociais ligados à comunicação. O mais importante, na informação e na comunicação, não são as ferramentas nem os mercados, mas [...] o ser humano, a sociedade e as culturas.”

(Dominique Wolton, 2004)

"Se contestamos a velocidade como virtude, devemos rejeitar a idolatria do mercado como síntese de organização social; descartar a velocidade como emblema atávico de evolução sócio-técnica; questionar euforias tecnológica

(o que em absoluto deve confundir-se com a tolice da tecnofobia); demarcar a necessidade ético-política de reverter a comercialização desenfreada da informação. Isso exige interpelação crítica e mobilizações sociais vigorosas para contrariar vivências midiatizadas e furar bolhas de consumo que banalizam aspirações, dissolvem bens simbólicos no puro valor de troca e consagram exclusões. É essa reação incisiva que pode nos fornecer a chave de resposta, numa perspectiva de humanização da existência.”

(Dênis de Moraes, 2009) 


\section{RESUMO}

A presente dissertação aborda os diferentes aspectos que impulsionam a demanda pelo reconhecimento do direito humano à comunicação como um direito fundamental, assim como as características teóricas que compõe o escopo deste novo direito. A partir do relato histórico sobre a evolução dos meios de comunicação, aponta o papel da comunicação mediada por tecnologias no desenvolvimento e reprodução do capitalismo, e descreve as peculiaridades atuais do modelo brasileiro, constatando a insuficiência do direito à liberdade de expressão e do direito à informação para a garantia da dignidade humana no campo da comunicação - na medida em que os mesmos não impediram a privatização da esfera pública.

Evidencia, a partir de pesquisa documental relacionada às iniciativas gestadas no âmbito do governo federal, como os proprietários dos meios de comunicação brasileiros se apropriaram destes princípios jurídicos, utilizado-os, no plano político e jurídico, como instrumento para obstrução de políticas públicas e regulatórias, na busca da perpetuação de privilégios no campo da comunicação. Apresenta o direito à comunicação como um direito guarda-chuva, abrigo de uma série de outros direitos e liberdades, na busca da superação da limitação historicamente imposta à compreensão da liberdade de expressão e do direito à informação, avançando rumo ao direito à participação na esfera pública em condições de igualdade material. No DHC se encontram direitos e liberdades que possuem relação com o campo da comunicação, mas que historicamente foram considerados de forma estanque e sem conexão. Defende a tese que o reconhecimento oficial do direito à comunicação no plano jurídico é a melhor forma garantir a dignidade humana neste campo, dando unidade e coerência aos princípios que possuem algum tipo de interface com o tema, assim como melhor definindo o perfil da pretensão a qual se almeja que os cidadãos e grupos sociais devem exercer.

Palavras-chave: direito à comunicação, mídia, direitos humanos, liberdade de expressão, direito à informação, esfera pública, igualdade. 


\section{ABSTRACT}

This dissertation deals with different aspects that imposes the demand for recognition of Communication Rigths as a fundamental right, and presents the characteristics that compose the scope of this "new" human right. The chronicle of communications technologies points out its role in the development and reproduction of capitalism, and describes the current peculiarities of the Brazilian model, noting the insufficiency of the legal principle of freedom of expression and the right to information to guarantee human dignity in the communications field. From the research of documents related to the initiatives of the federal government, this work shows how Brazilian media's owners uses these principle and right as a political and legal tool to obstruct regulatory and public policies, seeking perpetuation of privileges in the communication field. It also presents Communication Rigths as an umbrella shelter of a series of other rights and freedoms, in order to overcome imposed limitation on the historical understanding of freedom of expression principle and right to information, moving towards the right to participate in the public sphere on equal terms. The communications rights deals with rights and freedoms which are related to the communication field, but were historically considered unconnected.

Finally, this study argues that official recognition of the communications rights as human rights is the best way to ensure dignity, giving unity and coherence to the principles related to the topic, and better defining the claim which citizens and social groups should have.

Keywords: communication rights, media, human rights, freedom of expression, right to information, public sphere, information and communication tecnologies 


\section{Sumário}

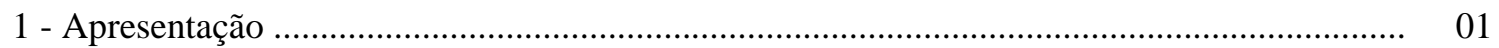

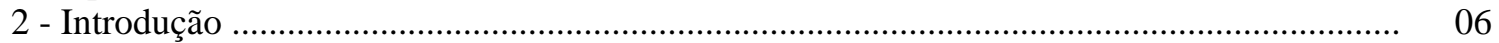

2.1 - Os capítulos da dissertação ................................................................................ 12

\section{PARTE 1}

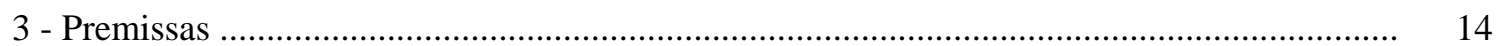

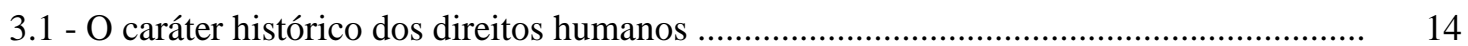

3.2 - Linguagem e natureza humana ............................................................................. 16

3.3 - Comunicação: em busca de uma definição .................................................................. 18

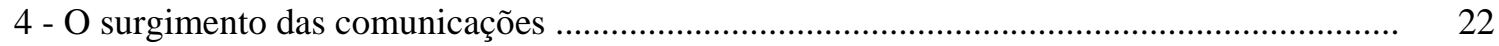

5 - Liberdade de expressão: sob o signo do liberalismo .................................................... 25

5.1 - O direito à informação e a consolidação do sujeito passivo ....................................... 30

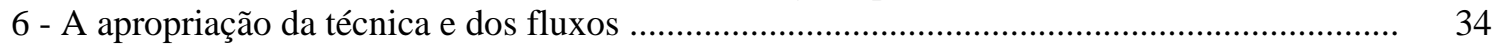

6.1 - As telecomunicações nacionais ............................................................................... 36

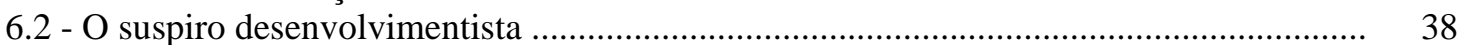

6.3 - Reforma do Estado: a privatização das telecomunicações ............................................ 40

6.4 - A hegemonia da radiodifusão privada-comercial ...................................................... 44

6.4.1 - As garras do coronelismo eletrônico.......................................................... 45

6.5 - Convergência e concentração.............................................................................. 50

\section{PARTE 2}

7 - Esfera pública e comunicação................................................................................. 56

7.1 - Imaginário e esfera pública ................................................................................... 58

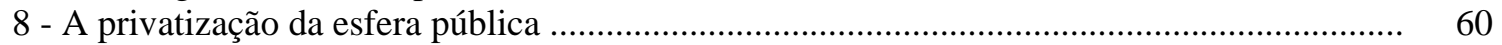

8.1 - A marca da apropriação nativa .......................................................................... 62

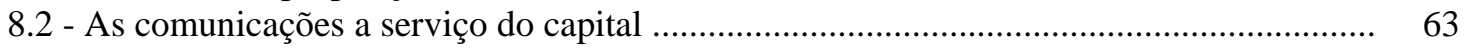

8.3 - Novas mídias, novos desníveis ................................................................................ 65

8.4 - A consolidação das desigualdades ......................................................................... 68

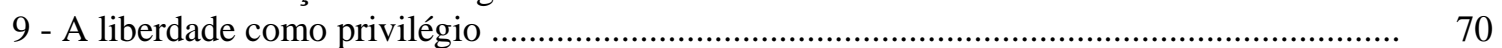

9.1 - A Agência Nacional do Audiovisual ............................................................................. 72

9.2 - O Conselho Federal de Jornalismo ........................................................................... 77

9.3 - Classificação Indicativa ....................................................................................... 80

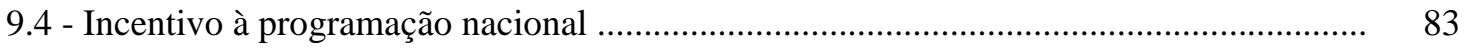

9.5 - A regulação da publicidade comercial ................................................................... 84

10 - Síntese conclusiva: em busca da recomposição da liberdade .......................................... 92

\section{PARTE 3}

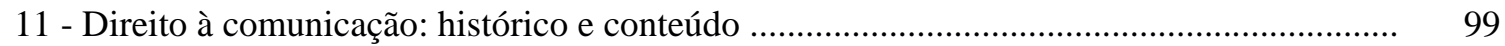

12 - A expansão do direito à comunicação ......................................................................... 110

12.1 - Direito guarda-chuva ................................................................................. 112

12.1 - Localização e titularidade .................................................................................. 113

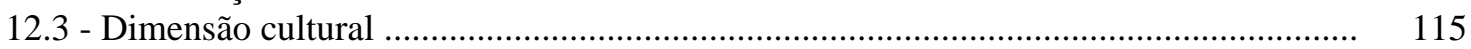

12.4 - Equilíbrio entre direitos fundamentais ............................................................... 116

12.5 - Educação e autonomia em relação aos meios de comunicação ................................... 117 
12.6 - Participação e controle social ................................................................................... 118

12.7 - Comunicação não-comercial ................................................................................... 119

12.8 - Proteção e direito de resposta ....................................................................................... 120

12.9 - Acesso às novas tecnologias e gestão das redes ........................................................... 121

13 - Em busca da utopia .................................................................................................... 124

14 - Conclusões ........................................................................................................ 131

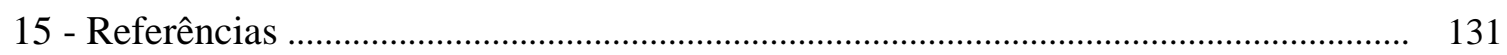

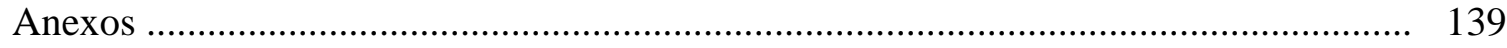




\section{1 - APRESENTAÇÃo}

O presente estudo possui dois objetivos centrais. O primeiro é apresentar subsídios coerentes que justificam o reconhecimento de um novo direito humano: o direito à comunicação ${ }^{1}$. Tal objetivo emerge da constatação da insuficiência dos princípios jurídicos ${ }^{2}$ da liberdade de expressão e do direito à informação para a garantia da dignidade humana no campo da comunicação. O segundo, a partir da hipótese que por ora se apresenta - a de que os atores sociais que reivindicam o reconhecimento, garantia e efetivação desse novo direito possuem razões objetivas que justificam tal atitude - é apresentar uma sistematização dos elementos que compõem o escopo deste novo direito, com a exposição de reflexões acerca da qualificação e da titularidade do direito à comunicação.

Nessa perspectiva, a dissertação a ser desenvolvida possui como característica central a interdisciplinaridade. Apoiar-se-á especialmente em elementos da História, da Sociologia e da Filosofia do Direito, dos Direitos Humanos, do Direito Econômico (em especial no que se refere à Teoria da Regulação), na Economia Política da Comunicação e em diferentes modelos teóricos para os estudos do fenômeno da Comunicação. Com menor ênfase, mas com igual importância para atingir os objetivos propostos, são apropriados elementos da Psicologia e da Pedagogia. Não menos importante para a articulação das reflexões apresentadas é a organização do discurso dos atores políticos e econômicos, nacionais e internacionais, que atuam na defesa de direitos ou, inversamente, na manutenção de privilégios no campo da comunicação.

A interdisciplinaridade é a essência da Comunicação Social enquanto campo intelectual ${ }^{3}$ e,

\footnotetext{
${ }^{1}$ Os termos ‘direito humano à comunicação’ e ‘direito à comunicação’, assim como sua sigla (DHC), para fins desta dissertação, devem ser considerados sinônimos.

${ }^{2}$ O conceito de princípio jurídico no campo específico dos direitos humanos é aqui utilizado na formulação proposta por Robert Alexy (2008). Segundo o autor, princípios são normas jurídicas que se distinguem das demais - chamadas de regras - em razão de três características essenciais: a supremacia normativa, a não delimitação formal e substancial do seu âmbito de incidência e a permanência em vigor nas hipóteses de conflito normativo.

${ }^{3}$ Como observam Armand e Michèle Mattelart: “(...) situados na encruzilhada de várias disciplinas, os processos de comunicação suscitam o interesse de ciências tão diversas quanto a filosofia, a história, a geografia, a psicologia, a sociologia, a etnologia, a economia, as ciências políticas, a biologia, a cibernética ou
} 
simultaneamente, é este também o caráter da disciplina dos Direitos Humanos ${ }^{4}$, o que sugere ser impossível, ao fazer parte deste programa da Faculdade de Direito da Universidade de São Paulo, negar ou tergiversar sua essência. Entende-se, também, que ao propor relacionar o universo das comunicações ${ }^{5}$ às teorias jurídicas que justificam o alargamento - ou expansão - dos direitos humanos, não havia outro caminho a seguir.

Assim, da proposta de relacionar campos de conhecimento (o Direito e a Comunicação Social) cuja interface ainda se revela pouco explorada por estudos acadêmicos, emerge o que este autor julga, com a humildade necessária, ser o elemento inovador desta dissertação: a articulação dos pressupostos histórico-filosóficos dos direitos humanos ligados às práticas comunicativas, como a liberdade de expressão e o direito à informação com (1) a evolução dos meios de comunicação e seu papel como estrutura de desenvolvimento e reprodução do capitalismo; (2) a simultânea emergência da centralidade à vida humana da comunicação mediada por tecnologias, a partir da busca por elementos que atestem a relação orgânica entre comunicação e dignidade humana; (3) a apresentação de particularidades das comunicações brasileiras, com a exposição de casos paradigmáticos; (4) os elementos discursivos dos proprietários e representantes dos principais meios de comunicação do país acerca dos direitos e liberdades humanas comunicativas; e (5) as demandas objetivas das organizações e movimentos que atuam em áreas cuja incidência se relaciona, direta e indiretamente, com as políticas regulatórias das comunicações.

Esta pesquisa, assim como todo trabalho científico, pressupõe, de início, as tarefas de levantar e sistematizar o conhecimento acumulado sobre o tema a ser explorado. Para esta

as ciências cognitivas” (1999, p. 43), ou Raymond Williams: “O especialista em comunicação se materializa em muitas especialidades distintas. Ele é um tipo sociólogo, preocupado com as instituições e seus efeitos. Ele é um tipo engenheiro, preocupado com as tecnologias e com os sistemas que é necessário planejar, entender e controlar. Ele é um tipo de crítico de cultura, preocupado com os significados e valores de produtos culturais (artefatos) particulares e classes de produtos culturais (...). Ele é um tipo psicólogo, preocupado com as unidades básicas e os padrões de interação comunicativa face a face ou no uso diferenciado de máquinas. Ou ainda, ele é um tipo lingüista ou filósofo da linguagem, preocupado com as formas básicas e estruturas dos atos de expressão e comunicação” (1979, p.1).

${ }^{4}$ É possível afirmar ser o próprio ethos da emergente disciplina interdisciplinar dos Direitos Humanos: é esse, pelo menos, o caráter do programa de pós-graduação no qual se insere esta dissertação.

${ }^{5}$ Por “universo das comunicações”, ou somente “comunicações”, entendem-se todas as dimensões dos processos comunicativos, como os que englobam os meios de comunicação, eletrônicos ou não, e seus impactos diversos nos indivíduos, nos grupos sociais e nas dinâmicas das diferentes sociedades. 
dissertação, foram determinados os dois objetivos centrais acima apresentados, que podem - e devem - serem vistos como interdependentes. Como objetivo secundário, a dissertação pretende contribuir para o debate público sobre o tema, no meio acadêmico, no meio político e no âmbito das entidades da sociedade civil que atuam na defesa dos direitos humanos.

\section{O PROBLEMA}

Após a conclusão da graduação em Comunicação Social (habilitação em rádio e TV) na Escola de Comunicações e Artes da Universidade de São Paulo, em 2001, e do exercício profissional como jornalista em alguns órgãos de imprensa sediados em São Paulo, atuo, desde 2002, como um dos coordenadores do Intervozes - Coletivo Brasil de Comunicação Social, organização que possui como objetivo lutar pela garantia e efetivação dos direitos e liberdades humanas no campo da comunicação social ${ }^{6}$. A partir do início de 2008, passei a compor o corpo de pesquisadores do Instituto Brasileiro de Defesa do Consumidor (IDEC) para a área de telecomunicações (telefonia móvel e fixa, TV por assinatura e Internet, basicamente).

A opção pelo Mestrado em Direitos Humanos, na Faculdade de Direito da USP, decorre da convicção alimentada nesses anos, de que a democracia contemporânea possui como exigência o reconhecimento do direito à comunicação - do qual fazem parte a liberdade de expressão e o direito à informação, entre outros direitos - como um direito humano. Esta afirmação se desdobra na seguinte afirmação: para seu efetivo reconhecimento, tal direito deve ser positivado como um direito fundamental.

\footnotetext{
${ }^{6}$ Considero o surgimento e fortalecimento do Intervozes um marco político importante relevante para o DHC, pois trata-se da primeira organização civil brasileira a possuir como missão primeira "promover o direito humano à comunicação, trabalhando para que este seja apropriado e exercido pelo conjunto da sociedade na luta por uma sociedade democrática, justa e libertária, construída por meio da autonomia, dignidade e participação de todos e todas”.
} 
O problema que ensejou a definição do projeto de pesquisa decorre da seguinte constatação: apesar dos avanços trazidos pela Constituição Federal de 1988 e das diversas lutas sociais, perdura no país a apropriação do espaço público da comunicação social pelos grandes capitalistas e pelas oligarquias nacionais. Tal fato, observável a partir de números e cifrões, mantém a violação permanente dos direitos à liberdade de expressão e informação, direitos estes imprescindíveis à realização plena da democracia. Por outro lado - e, no caso desta pesquisa, extremamente relevante - o mesmo ocorre com a comunicação (compreendida como o processo dialógico de troca de informações) que, mais grave, não é efetivamente reconhecida como um direito.

Coloca-se, portanto, a seguinte questão: como contribuir para o conhecimento sobre os obstáculos ao reconhecimento do direito à comunicação como um direito humano no Brasil (e como direito público subjetivo), assim como para a proposição de caminhos para a efetiva democratização das comunicações? Pretendo, nessa perspectiva, sistematizar e discutir as justificativas e dimensões do direito à comunicação em uma perspectiva transversal - ou seja, em sua relação com os direitos civis e políticos, e com os direitos culturais, econômicos e sociais - que evidencie ser a comunicação não só um um direitomeio para a promoção do conjunto dos direitos humanos, mas também um direito-fim fundamental para o respeito à dignidade humana.

\section{AGRADECIMENTOS}

À minha companheira, Anna Luiza, pelo amor e carinho, pela compreensão e pelo incentivo nas horas mais difíceis. À pequena Iara, que chegou para iluminar a minha vida.

Agradeço aos meus pais por me possibilitarem chegar até aqui e por estarem sempre ao meu lado. Obrigado por tudo. Amo vocês. 
À minha orientadora Maria Victoria, pelo acolhimento sempre carinhoso, pelo incentivo (e compreensão!) e por me ajudar a encontrar o caminho a ser perseguido.

Aos meus queridos companheiros e companheiras do Intervozes, bravos lutadores pela dignidade humana no campo da comunicação, a quem devo boa parte do que aprendi. À Estela Guerrini, cuja colaboração na reta final desta jornada foi das mais importantes. 


\section{2 - INTRODUÇÃO}

O campo de estudos das Comunicações, ou da Comunicação Social, frente aos demais campos das Ciências Humanas, pode ser considerado relativamente novo, e remonta aos primórdios do desenvolvimento da comunicação de massa no início do século XX. O fenômeno responsável por seu despertar aparece tardiamente na história da humanidade e se constitui numa das mais importantes características da modernidade, distinguindo-se da comunicação humana interpessoal pelo uso de tecnologias específicas e pelo surgimento de instituições inerentes ao seu funcionamento. Contemporaneamente, é o fenômeno que se convencionou chamar de meios de comunicação de massa ou mídia ${ }^{7}$. Alerta Mauro Wolf (1987), entretanto, que mesmo estes termos sofrem mutações em seu significado, pois são, simultaneamente, "um importante setor industrial, um universo simbólico objeto de consumo de massa, uma experiência individual cotidiana, um terreno de confronto político, um sistema de intervenção cultural e de agregação social, uma maneira de passar o tempo”, etc, sendo o objeto teórico, "por vezes constituído pelos meios de comunicação de massa e, outras vezes, pela cultura de massa” (Wolf, 1987, p. 9).

É também fato inconteste que as teorias das comunicações necessariamente contêm, implícita ou explicitamente, uma teoria social. Como sustenta Stuart Hall (1989),

“[a comunicação] está inevitavelmente ligada ao sucesso, à eficácia ou
ineficácia das teorias da formação social como um todo, porque é neste
contexto que deve ser teorizado o lugar da comunicação no mundo social
moderno [...] a comunicação não pode ser conceituada como externa ao
campo das estruturas e práticas sociais porque é, cada vez mais,
internamente constitutiva delas. Hoje, as instituições e relações
comunicativas definem e constroem o social; elas ajudam a construir o
político, elas medeiam as relações econômicas produtivas. Elas se tornam

\footnotetext{
${ }^{7}$ Em latim, “meio" se dia medium e, no plural, “meios” se diz media. Os primeiros teóricos dos meios de comunicação empregaram a palavra latina media. Como eram teóricos de língua inglesa, diziam: mass media, isto é, os meios de massa. A pronúncia, em inglês, do latim media é "mídia”. Quando os teóricos de língua inglesa dizem “the media”, estão dizendo: "os meios". Por apropriação da terminologia desses teóricos no Brasil, a palavra mídia passou a ser empregada como se fosse uma palavra feminina do singular - "a mídia" (Chauí, 2006, p. 35).
} 
'força material' nos modernos sistemas industriais; elas definem a própria tecnologia; elas dominam o cultural” (Hall, 1989, p. 43).

Não é difícil, pois, como aponta Mauro Wilton de Sousa (2006), compreender porque a análise da comunicação não é estranha à análise dos modelos de sociedade. Assim, “do reconhecimento da presença e da importância da técnica na constituição dos meios de comunicação, e estes na construção do que se entende hoje por comunicação, esta passou a ser, pelo concurso daqueles, a própria categoria explicativa fundamental da sociedade contemporânea” (Sousa, 2006, p. 15).

É forçoso reconhecer, no entanto, que o campo de estudos da comunicação é composto por um universo teórico desarticulado e conflituoso, com modelos de difícil classificação, cujos principais expoentes advêm, pelo menos originariamente, de outros campos das Ciências Humanas. Apesar dessas dificuldades, os modelos utilizados para a análise do fenômeno das comunicações e de sua influência/relação na vida humana e social foram sistematizados por pesquisadores como Venício Artur de Lima (2001), Armand e Michèle Mattelart (1999), Bernard Miège (2000) e Mauro Wolf (1994), o que permite distinguir as características centrais de cada um deles, como por exemplo o Funcionalismo e as Teorias da Manipulação e Persuasão, a Escola de Frankfurt e os Estudos Culturais, todos estes, sem exceção - exatamente por serem teorias sociais -, presentes também em outras áreas de conhecimento: na Escola de Frankfurt, por exemplo, incluem-se pensadores pouco alinhados, como Adorno e Habermas, importantes referências nas Ciências Sociais e no Direito; nos Estudos Culturais, autores como Stuart Hall, Raymond Williams e Jesus Martín-Barbero, também referências valorizadas nas Ciências Sociais.

No “mundo da vida”, como diria Habermas, há quase uma década organizações dos mais diferentes perfis - de movimentos populares e sociais às organizações não-governamentais atuantes em diversas áreas de direitos humanos - vêm progressivamente se apropriando do termo “direito humano à comunicação" ou simplesmente "direito à comunicação". Sem deixar de enfatizar as questões pertinentes às suas demandas ou aos seus focos específicos, como a defesa dos direitos das crianças e adolescentes, da igualdade racial ou de gênero, das pessoas com deficiência, dos trabalhadores rurais, do acesso à fruição das artes e da 
cultura popular, dos direitos do consumidor, entre outros, estas entidades parecem ter encontrado um conceito capaz de organizar o discurso dos que defendem mudanças na forma como os meios de comunicação social são explorados e regulados no Brasil, dando ao movimento "pela democratização da comunicação" - composto histórica e majoritariamente por jornalistas sindicalizados - dimensão anteriormente inexistente. A força com que emerge o tema (em forma de reivindicação pelo reconhecimento do direito à comunicação enquanto princípio jurídico), após quase trinta anos da publicação pela UNESCO do Relatório Um Mundo, Muitas Vozes ${ }^{8}$, impõe a necessidade de buscar respostas às questões ainda pouco investigadas.

A primeira dessas questões decorre justamente da necessidade de reconhecimento da comunicação enquanto direito humano, a partir da qual podem ser feitas indagações que apontem respostas a serem perseguidas nesta e em outras pesquisa futuras. Aqui, tentamos discutir, porque a demanda pelo DHC ressurgiu vinte anos da publicação do Relatório Macbride, após um período em que o conceito caiu praticamente no ostracismo: o que terá mudado neste período? Foi uma mudança na estrutura de exploração das comunicações eletrônicas? Foi a expansão do uso da Internet e a digitalização dos conteúdos de áudio, vídeo e texto? Foi o reconhecimento crescente pelas organizações que atuam em outros campos de direitos humanos (que não a comunicação social) da necessidade de enfrentar as violações cometidas diariamente pelos veículos de comunicação de massa (e por que isso teria ocorrido?)? Foi a radicalização destas violações nos últimos anos, a partir do movimento de concentração de mercado inerente à dinâmica capitalista? E por que isso ocorre com maior vigor nos países da América Latina, apesar do discurso pelo reconhecimento do direito à comunicação também estar presente na Europa e nos EUA? Terá sido uma reação à onda neoliberal que se alastrou pelo mundo na década de 1980, mas que só atingiu em cheio os países da América Latina na década de 1990 sem que os direitos sociais e econômicos tivessem sido minimamente efetivados? Ou foi uma combinação destes fatores somada ao crescente apelo dos proprietários dos meios de comunicação ao princípio jurídico da liberdade de expressão e informação para evitar qualquer tipo de

\footnotetext{
${ }^{8}$ O Relatório Um Mundo, Muitas Vozes, publicado em 1980 pela UNESCO, é o principal marco histórico das discussões sobre o reconhecimento do direito à comunicação e será retomado no capítulo 11 desta dissertação.
} 
regulação sobre suas atividades? Ou, ainda, foi a ausência de reconhecimento - no plano objetivo (material) e discursivo - pelos Poderes Executivo e Judiciário da existência de um direito mais amplo do que o direito à prestação negativa do Estado, reconhecido historicamente no princípio da liberdade de expressão?

Tais indagações apontam ser a afirmativa de Bobbio - segundo a qual “o problema fundamental em relação aos direitos do homem, hoje, não é tanto o de justificá-los, mas o de protegê-los” (1992, p. 24, grifos do autor) - inaplicável integralmente aos direitos e liberdades comunicativas. A orientação desta pesquisa parte da convicção de que a justificativa e o reconhecimento - jurídico, político e social - do direito humano à comunicação são ainda crucialmente necessários, ao lado, evidentemente, de sua efetivação.

A segunda questão pouco explorada nas últimas décadas se refere à compreensão dos direitos e liberdades decorrentes do princípio jurídico do direito à comunicação. Desde 1969, quando o conceito foi pela primeira vez tornado público - também no âmbito da UNESCO - o direito à comunicação tem sido compreendido como um prolongamento dos princípios da liberdade de expressão e informação, acrescentando a estes o direito de produzir e, mais importante, veicular estas informações, o que necessariamente imputa aos Estados a responsabilidade de garantir os meios indispensáveis ao exercício deste direito.

Como a análise do próprio relatório da UNESCO aponta, a origem do DHC como conceito está intimamente ligada à leitura conjuntural realizada entre as décadas de 1950 a 1970 por pesquisadores dos países subdesenvolvidos, que viam no fluxo desigual de informação e produções culturais entre os países (em especial dos EUA para as nações da América Latina, da África e da Ásia) um desequilíbrio sistêmico com forte impacto na produção simbólica das populações dessas regiões, com resultados não só na fruição dos direitos culturais destes povos, mas também em seu desenvolvimento econômico e social, uma vez que o setor audiovisual era, e continua sendo, um dos mais fortes segmentos da economia mundial. 
Apesar desta relação entre o centro e a periferia capitalista se manter vigorosamente desigual, os quase 30 anos passados da produção do Relatório Macbride coincidem com o despertar das chamadas novas tecnologias de informação e comunicação (TICs) e da convergência digital, fenômeno especialmente radicalizado pelo surgimento e expansão das redes IP (Internet Protocol), imputando às redes de telecomunicações importância política, social e cultural inexistente no tempo do "velho" telefone fixo. Não à toa, é neste contexto que proliferam as políticas públicas que visam promover a “inclusão digital”, numa clara referência às novas condições para a garantia da dignidade humana.

É também da possibilidade de troca de conteúdos pelas redes de telecomunicações que se consolidam as iniciativas de apropriação da informação pelos detentores conexos de propriedade intelectual (gravadoras, estúdios de cinema, editoras, empresas de software), que, apoiados em tratados firmados no âmbito da Organização Mundial de Comércio (OMC), buscam criminalizar certas práticas, como a simples - e trivial, diga-se - prática da troca de arquivos pela Internet. Como resistência, organizações civis, intelectuais e até instituições de Estado reivindicam maior equilíbrio entre os direitos de propriedade intelectual e o direito ao conhecimento e à cultura, tratados por estas mesmas organizações e intelectuais sob o "guarda-chuva” do direito à comunicação.

É possível afirmar, também, o crescimento progressivo do número de organizações atuantes em áreas diversas dos direitos humanos que se referenciam no princípio do direito à comunicação para exigir a efetivação de direitos difusos e coletivos que não constam na formulação apresentada pela UNESCO entre as décadas de 1960 e 1980, como o direito à não discriminação de grupos específicos ou à proteção contra a publicidade abusiva, que, somados às demandas emergentes das novas possibilidades tecnológicas, dão nova dimensão ao direito à comunicação.

Trata-se, portanto, de enfatizar a pergunta em relação ao escopo atual do direito à comunicação. Quais seriam de fato os direitos e liberdades decorrentes da afirmação do DHC enquanto princípio jurídico? Dito em outras palavras: o que seu reconhecimento amplo, com sua possível positivação na Constituição Federal ou em tratados 


\begin{abstract}
internacionais acarretaria, especialmente em relação às obrigações estatais positivas, tanto na forma de regulação quanto por meio de políticas públicas? Apesar da dificuldade de delimitação formal do seu âmbito de incidência - dificuldades estas características dos princípios jurídicos - sem respostas a esta questão o direito à comunicação, apesar de reivindicação legítima, dificilmente ganhará status de direito fundamental.
\end{abstract}

Derivada destas reflexões, outra resposta merece ser perseguida. Quais são os atributos jurídicos do direito à comunicação? Quem são os titulares do direito subjetivo ao qual se busca o reconhecimento? Se a formulação realizada no âmbito da Unesco aponta na direção de avançar o DHC rumo à titularidade coletiva, quais as implicações da redefinição do escopo do direito emergente, a partir das demandas apresentadas pelas organizações sociais que hoje atuam em sua defesa? Por ser o direito à comunicação o abrigo de outros direitos e liberdades, haveria uma “combinação de titularidades", incluindo as titularidades individual, coletiva e difusa? Como e quando estas diferenças se manifestam? Esboçar respostas a estas questões parece relevante para qualificar a atuação dos que buscam a garantia dos direitos humanos no campo das comunicações.

Em síntese, a reflexão e a pesquisa a serem desenvolvidas buscam contribuir para o debate acerca do reconhecimento do direito humano à comunicação. Não se almeja ou ambiciona, evidentemente, encerrar possíveis polêmicas ou determinar de forma categórica os diferentes aspectos sobre a emergência deste novo direito humano. Acredita-se, ao contrário, que a contribuição maior desta dissertação será a organização das questões ainda não respondidas que possuem relação direta com o reconhecimento do DHC, a serem investigadas pelo conjunto de pesquisadores que, como este autor, acreditam ser o campo da comunicação espaço prioritário e indispensável para a garantia e efetivação do conjunto dos direitos humanos, no Brasil e no mundo. 


\section{1 - Os capítulos da dissertação}

O presente estudo é composto por 10 capítulos, divididos em três partes.

Na primeira parte - dos capítulos 3 ao 6 - são expostas as premissas necessárias ao desenrolar da dissertação. No Capítulo 3 são abordadas as definições de “direitos humanos” e “comunicação” com as quais se identifica e que compõe os alicerces do presente trabalho. No mesmo capítulo são tecidas considerações sobre o emprego da linguagem pelos seres humanos. No capítulo 4 é feito um relato do desenvolvimento inicial dos meios de comunicação de massa. No capítulo seguinte são expostas as bases sobre as quais se constituiu a identidade dos princípios jurídicos da liberdade de expressão e do direito à informação. No capítulo 6 é apresentado um relato histórico do desenvolvimento das comunicações no Brasil (incluindo a radiodifusão e as telecomunicações), buscando transparecer, especialmente a partir da Economia Política da Comunicação, as características atuais dos principais serviços existentes no país.

Na segunda parte - que engloba os capítulos de 7 ao 10 - se busca relacionar, de modo sistêmico, a organização da exploração das comunicações com as violações estruturais à dignidade humana, por meio da exposição e discussão dos conceitos de esfera pública e imaginário social. Dessa forma, no capítulo 7, se apresenta justamente o conceito de esfera pública desenvolvido por Jürgen Habermas. No capítulo 8, a partir das características expostas no capítulo 6, são tecidas considerações sobre o desvirtuamento desta esfera pública, após sua apropriação pelo Capital e pelas oligarquias regionais ainda fortemente presentes no Brasil. No capítulo seguinte, busca-se revelar como o princípio jurídico da liberdade de expressão tem sido utilizado como instrumento para a perpetuação de privilégios no campo da comunicação. Para tanto, apoiar-se-á em pesquisa documental realizada nos grandes veículos impressos e eletrônicos, nas manifestações oficiais dos proprietários dos principais grupos privados de comunicação e das associações de classe que os representam, como a ABERT (Associação Brasileira de Emissoras de Rádio e Televisão), a ABRA (Associação Brasileira de Radiodifusores), a ANJ (Associação Nacional de Jornais), a ANER (Associação Nacional de Editores de Revistas), a ABAP 
(Associação Brasileira de Agências de Publicidade) e a ABTA (Associação Brasileira de Televisão por Assinatura). O último capítulo desta parte é reservado a uma síntese reflexiva sobre a compreensão hegemônica dos princípios jurídicos da liberdade de expressão e do direito à informação, buscando apontar os impactos objetivos dessa hegemonia.

A terceira parte é composta pelos capítulos 11, 12 e 13. No capítulo 11, a partir de pesquisa bibliográfica e documental, é apresentado um relato histórico do surgimento do direito à comunicação como demanda político-jurídica, na busca de uma definição precisa sobre seu conteúdo. Em seguida - a partir de pesquisa realizada especialmente em documentos de organizações da sociedade civil que se relacionam, de forma direta e indireta com as comunicações - se arrisca uma síntese de características e elementos que justificam, para além das construções históricas consolidadas no âmbito da UNESCO, o reconhecimento do direito à comunicação. Por fim, no capítulo 13, são tecidas considerações sobre as diferentes visões sobre a necessidade de reconhecimento formal do direito humano à comunicação nos marcos jurídicos nacionais e internacionais. 


\section{3 - PREMISSAS}

A apresentação de alguns conceitos é imprescindível ao desenrolar desta dissertação. Mais do que definições estáticas e herméticas de palavras ou termos, são juízos - apropriados de autores com os quais se identifica, evidentemente - sem os quais seria impossível a articulação de idéias que se pretende desenvolver. Longe da pretensão de construir teorias sobre estas expressões, busca-se tão somente indicar a perspectiva sob a qual devem ser compreendidos.

\section{1 - O caráter histórico dos direitos humanos}

Os direitos humanos são os direitos inerentes à própria condição humana, decorrentes do núcleo fundador do direito à vida, sem particularidades determinadas de indivíduos ou grupos. São direitos que todos os seres humanos possuem, independentemente de diferenças biológicas e culturais, de gênero, etnia, classe social, grupo religioso, entre outras, e que, hoje, fazem parte da consciência moral e política da humanidade (Comparato, 2003).

Foi durante o período axial da História que despontou a idéia de uma igualdade essencial entre todos os humanos. A convicção de que todos os seres humanos possuem direitos a serem igualmente respeitados, no entanto, nasce vinculada ao surgimento da lei escrita como regra geral aplicável a todos os indivíduos que vivem em uma sociedade organizada (Ibidem). Entre os modernos, a doutrina dos direitos humanos (ainda hoje chamada por alguns de “direitos do homem”) tem origem na filosofia jusnaturalista, a qual, para justificar a existência de direitos pertencentes aos seres humanos, partira da hipótese de um estado de natureza onde os direitos do homem são poucos e essenciais: o direito à vida e à sobrevivência (que inclui também o direito à propriedade); e o direito à liberdade, que compreende liberdades essencialmente negativas ${ }^{9}$.

\footnotetext{
${ }^{9}$ A teoria do direito natural abrange uma grande parte da filosofia de Tomás de Aquino, Francisco Suárez, Richard Hooker, Thomas Hobbes, Hugo Grócio, Samuel von Pufendorf e John Locke, e exerceu uma influência profunda no movimento do racionalismo jurídico do século XVIII, quando surge a noção dos direitos fundamentais, e no desenvolvimento da common law inglesa. O uso do direito natural, em suas
} 
Como alerta Bobbio (1992), entretanto, este estado de natureza é “uma ficção doutrinária, que devia servir para justificar, como direitos à própria natureza do homem (e, como tais, invioláveis por parte dos detentores do poder público, inalienáveis pelos seus próprios titulares e imprescritíveis por mais longa que fosse a duração de sua violação ou alienação), exigências de liberdades provenientes dos que lutavam contra o dogmatismo das Igrejas e contra o autoritarismo dos Estados” (Bobbio, 1992, p. 74).

Nessa perspectiva, embora o conceito de dignidade seja aplicável em qualquer tempo histórico, as condições nas quais nasceram as sucessivas exigências por direitos devem ser buscadas não na hipótese do estado de natureza, “mas na realidade social da época, suas contradições, nas mudanças que tais contradições foram produzindo em cada realidade concreta" (Ibidem, Id.).

Enquanto a relação entre as transformações sociais e o nascimento das liberdades individuais de primeira geração era menos evidente - podendo assim dar vida à hipótese de que a exigência de liberdades civis era fundada na existência de direitos naturais, pertencentes ao homem enquanto tal -, a relação entre a demanda pelos chamados direitos de segunda geração e a transformação da sociedade é certa: as exigências de direitos sociais se tornaram tanto mais numerosas quanto mais rápida e profunda foi a transformação da sociedade.

A aspiração por intervenção pública em diversos aspectos da vida, por exemplo, só podem existir num determinado nível de desenvolvimento econômico e tecnológico; e são precisamente certas transformações sociais e inovações técnicas que fazem surgir novas reivindicações imprevisíveis e inexeqüíveis antes que essas transformações e inovações tivessem ocorrido. Chama a atenção, quando se analisa a sucessão das diferentes etapas de sua afirmação, o "sincronismo entre as grandes declarações de direitos e as grandes descobertas científicas ou invenções técnicas” (Comparato, 2003, p. 37).

sucessivas encarnações, contudo, variou consideravelmente ao longo da história. Há diversas teorias do direito natural, que divergem quanto ao papel da moral na determinação da autoridade das normas legais. 
A própria evolução dos direitos humanos é geralmente destacada em três dimensões (ou gerações) justamente por seu caráter evolutivo, e não exclusivamente biológico: às liberdades reconhecidas no século XVIII, foram acrescidos os direitos sociais do século XIX e meados do século XX. Nas últimas décadas e ainda hoje, são objeto de exigência os chamados direitos coletivos da humanidade, que, de forma geral, referem-se à defesa do meio-ambiente, à paz, ao desenvolvimento, à autodeterminação dos povos e à partilha do patrimônio científico, cultural e tecnológico. São os chamados direitos de "solidariedade planetária”, que, certamente, seriam impossíveis de serem imaginados e, portanto, exigidos e reconhecidos, nos séculos anteriores.

É este o ponto de partida, que acredita serem os humanos dotados de preferências valorativas, de autonomia e de auto-consciência, que pode justificar a emergência de novos direitos: enquanto históricos, são mutáveis, ou seja, suscetíveis à transformação e ampliação. "Só ele [o ser humano] tem a memória e a consciência de sua subjetividade, de sua história no tempo e no espaço e se enxerga como um sujeito no mundo, 'orgânico' e mortal. Só o humano pode desenvolver suas virtualidades no sentido da cultura e do autoaperfeiçoamento vivendo em sociedade e expressando-se através do amor, da razão e da criação estética, qualidades essencialmente comunicativas. É o único ser histórico, que vive em perpétua transformação pela memória do passado e pelo projeto do futuro” (Benevides, 2004, p. 48).

\section{2 - Linguagem e natureza humana}

"A diferença fundamental entre o animal, cuja atividade não vai além de mera produção, e o homem, que cria o domínio da cultura e a história através de sua ação no mundo, é que apenas o último é um ser de práxis. O homem, em sua permanente relação com a realidade, produz não apenas bens materiais, coisas sensíveis e objetos, mas também instituições sociais, ideologias, arte, religiões, ciência e tecnologia” (Freire, 1983, p. 167-68). 
Os processos comunicativos estão presentes no cotidiano das mais diversas sociedades e grupos sociais. Um olhar atento para nós mesmo é suficiente para verificar que nos comunicamos racionalmente desde o momento em acordamos até o momento em que fechamos os olhos para dormir.

As diversas sociedade não podem prescindir de um código operacional que facilite a comunicação entre grupos e indivíduos. A linguagem é o meio simbólico essencial à constituição deste código como fator de identificação entre os sujeitos: é a consciência real, prática, existente, “a realidade imediata do pensamento”, que surge da "imperiosa necessidade de relacionamento com outras pessoas” (Marx e Engels, 1977, p. 30). Baseiase em signos e representações que circulam nos discursos e constituem a base da realização lingüística das relações sociais.

Mediadas pela linguagem, nossas relações com o mundo se tornaram progressivamente mais complexas. A linguagem “em ação” é a matriz dos processos de comunicação humana e, portanto, condição comum da espécie humana. Segundo constata-se, não foi encontrada nenhuma pessoa ou grupo tribal que não tenha desenvolvido algum sistema de linguagem (Trabers, 2001, p. 54). Em seu domínio, podemos propor, estabelecer e alterar significados de fatos, objetos e coisas do mundo, dependendo da capacidade de legitimar tais significados através de sua incorporação pela coletividade (Moraes, 2009, p. 30).

A partir dos códigos de gestos e vogais mais simples, inscritos na sua estrutura física, o ser humano entendeu e diversificou progressivamente toda uma série de meios não verbais de transmissão de mensagens: música e dança, tam-tam, sinais de fumaça, desenhos e outras formas de símbolos gráficos, que deram origem ao pictograma e mais tarde ao ideograma, cuja importância obedece ao fato de associar pela primeira vez a representação de um objeto a uma idéia abstrata (UNESCO, 1980, p. 4).

Os antigos já se debruçavam sobre a questão da linguagem. Platão definiu o ser humano como o "animal que fala" (zoon logon echon). Segundo o filósofo, os seres humanos "falam quando estão acordados e também quando dormem”. 
Mesmo a comunicação por sinais manuais ou desenhos - símbolos ou signos desenvolveu-se em processos sociais que pressupõe o uso da linguagem. A partir do desenvolvimento da escrita, a presença da comunicação mediada por suportes ou tecnologias tornou-se uma tendência irreversível.

Sem a linguagem não há relação com o outro. Sem a relação com o outro, não nos reconhecemos como sujeito, e, portanto, não há dignidade possível. É este, acredita-se, o fundamento natural do direito à comunicação.

\section{3 - Comunicação: em busca de uma definição}

Embora seja trivial e de uso freqüente em diferentes contextos, a palavra comunicação carrega até hoje uma ambigüidade não resolvida em seu significado original, cuja origem etimológica advém do substantivo latino communicationem, que significa "ação de tornar comum”. Sua raiz é o adjetivo communis, comum, que significa "pertence a todos ou a muitos”, e o verbo comunicare, que significa "tornar comum”, “fazer saber”, aproximando o termo tanto da idéia de compartilhar quanto de transmitir. "Pertence a todos ou a muitos", contudo, parece conferir ao termo uma intenção adicional à preconizada pelas teorias do início do século XX, que dão à comunicação um significado próximo a poder.

A ambigüidade inerente à etimologia do termo é assim ponderada por Venício Lima:

“A 'ação de tornar comum a muitos' pode ser resultado tanto de uma transmissão como de um compartilhamento, que são pólos opostos de uma ação de comunicar. Para que se transmita algo é preciso que se admita que esse algo possa ser apropriado e em seguida 'transmitido' a outro. Quando se compartilha, ao contrário, o que ocorre é uma co-participação, uma comunhão, um encontro. A distinção pode ser feita identificando-se, de um lado, uma comunicação manipulatória e, de outro, uma comunicação participativa” (2001, p. 25). 
Informação, por sua vez, possui raiz no adjetivo latino in formati, que significa "ação de delinear" e "ação de conceber idéia"; e do verbo formare, que pode ser compreendido como “dar forma” (Ferreira, 1997, p. 67). Assim como comunicação, o conceito de informação deve considerar que a mesma não existe fora de seu contexto social, por ser a relação entre o conteúdo de determinada informação e seu receptor, a única capaz de atribuir significado à mesma (Almino, 1986, p. 35).

A busca das origens etimológicas dos termos, assim, não simplifica a tarefa de distinção entre comunicação e informação, sendo ambos os conceitos aplicáveis a partir de relações sócio-simbólicas por meio do emprego da linguagem. A confusão se reproduz no universo acadêmico: o termo informação é utilizado principalmente pela academia francesa e por organizações internacionais como a UNESCO, ao passo que o conceito de comunicação tem sido historicamente utilizado pelos estudos de origem anglo-saxã, sem que isso signifique necessariamente uma diferença de abordagem relevante (Melo, 1796, p. 54).

À despeito dessa dificuldade, para que se apliquem às Ciências Jurídicas ambos os conceitos, é importante buscar uma definição mais precisa. Paulo Freire ${ }^{10}$, em abordagem realizada no ensaio Extensão ou Comunicação? publicado originalmente em 1969, pressupõe que não há comunicação sem a integração das partes ao processo. Coparticipação, reciprocidade, diálogo, encontro de sujeitos: nos termos do autor, comunicação, definitivamente, não pode ser confundida com transmissão, cuja ação pode ser unilateralmente protagonizada.

"Comunicação é a co-participação dos sujeitos no ato de pensar [...] implica uma reciprocidade que não pode ser rompida [...] comunicação é diálogo na medida em que não é transferência de saber, mas um encontro de Sujeitos interlocutores que buscam a significação dos significados” (Freire, 1983, p. $67)$.

\footnotetext{
${ }^{10}$ De acordo com V. Lima (1981), “Paulo Freire é um exemplo de autor prejudicado pela estreiteza da maior parte dos estudos de comunicação. Apesar de ser amplamente estudado em áreas afins, de a maioria de seus trabalhos estar disponível e de trabalhar com comunicação e cultura, não tem recebido a devida atenção por parte dos estudiosos de comunicação” (p. 10). A afirmação foi feita há 25 anos, em 1981, mas, pelo que foi possível verificar durante as pesquisas feitas para esta dissertação, não há indícios de que a situação tenha sido alterada.
} 
Apesar de não ser explícito, Freire parece se apoiar em outro conceito caro ao conjunto das Ciências Humanas: trata-se da idéia de igualdade, necessária, enquanto relação, para a reciprocidade defendida como inerente ao conceito de comunicação. Essa noção exclui a relação de poder nos processos de troca de informação, ao menos naquilo que Freire nomeia como comunicação autêntica. Nessa perspectiva, informação deve ser compreendida como elemento - mas não a totalidade - do processo comunicativo ${ }^{11}$.

Cumpre apontar que a acepção proposta por Freire é de extrema relevância no plano jurídico, pois, como aponta Cees J. Hamelink (2005), “praticamente todos os dispositivos de direitos humanos referem-se à comunicação como 'transferência de mensagens'. Isto reflete uma interpretação da comunicação que se tornou bastante comum desde que Shannom e Weaver (1949) introduziram a teoria matemática da comunicação. O seu modelo descreve a comunicação de forma linear, como um processo de mão única. Isto é, contudo, uma concepção muito limitada e por vezes enganosa de comunicação, por ignorar o fato de que, na essência, 'comunicar' refere-se a um processo de compartilhar, tornar comum ou criar uma comunidade” (Hamelink, 2005, p.143).

Baseado nessa perspectiva, o termo comunicação, apesar da ambigüidade original, deve ser compreendido como (1) um processo, e não um ato unilateral, que se diferencia, portanto, de transmitir, informar ou expressar e (2) um processo no qual está presente uma relação, sendo esta relação é necessariamente de igualdade entre os que participam do processo comunicativo. Comunicação, para que seja entendida como tal, pressupõe que os envolvidos sejam protagonistas de um processo cuja premissa é a ausência de poder. Poder, neste contexto, impõe o monólogo. Igualdade, por outro

\footnotetext{
${ }^{11}$ Como é notório, a maior parte do trabalho de Freire é devotada ao problema da educação, ou àquilo que ele chama de “ação cultural”. V. Lima (1981) aponta que Freire chega a equiparar comunicação com educação, uma vez que utiliza os termos indistintamente e também os iguala em sua epistemologia. "Ao nível social, os sistemas de comunicação - sobretudo a comunicação de massa -, podem ser considerados como tendo a mesma função simbólico-ideológica dos sistemas educacionais nas sociedades capitalistas” (1981, p. 11). Assim como nomeia o que acredita ser a verdadeira comunicação uma “comunicação autêntica”, Freire faz o mesmo, em diversas passagens do ensaio, com o termo educação.
} 
lado, permite o diálogo, o exercício da liberdade de expressão por todos e, portanto, a comunicação $^{12}$.

Com esta definição se busca afirmar sobretudo o sentido da comunicação, seu ethos, ou, dito de outra forma, a sua utopia, sob a qual, a partir do momento em que a comunicação já não mais se refere somente às relações interpessoais e passa a ser um processo socialmente organizado por tecnologias e suportes, se constrói o paradigma do direito humano à comunicação.

\footnotetext{
${ }^{12}$ Bertold Brecht, antecipando-se à definição de Freire, aplicando-a e aproximando-a à nascente comunicação de massa (ao rádio, no caso), já sinalizava a necessidade da relação de igualdade para que o fluxo de informações se constituísse em comunicação. Em 1932, em texto hoje célebre nos estudos de comunicação, defende que "o rádio deve deixar de ser um meio de distribuição para se transformar num meio de comunicação. Seria o meio de comunicação mais maravilhoso que se pode imaginar na vida pública, uma imensa rede, e o seria se fosse capaz não só de emitir mas também de receber, de permitir ao ouvinte ouvir e também falar e, assim, em lugar de se isolar, facilitar-lhe-ia o contato” (Brecht, 2005).
} 


\section{4 - O SURGIMENTO DAS COMUNICAÇÕES}

A história das comunicações é tão antiga quanto a história das sociedades. Desde o longínquo desenvolvimento da linguagem oral, dos primeiros pictogramas e imagens, a humanidade percorreu milhares de anos em permanente desenvolvimento de técnicas para a produção e transmissão de conteúdos, em uma busca incessante para encurtar o tempo de circulação da informação.

Internamente às sociedades, se desenvolveram meios e formas de difusão de conteúdos simbólicos de diversa naturezas, utilizando um número cada vez maior de suportes e materiais. Simultaneamente, foram se aprimorando meios de comunicação que reduziram progressivamente o tempo de circulação de mercadorias, entre as quais esteve, desde sempre, a informação. Das mais rudimentares trilhas surgiram as estradas, ferrovias e redes de telecomunicações, encurtando a noção de tempo e espaço, em um processo em constante expansão (Dantas, 2002).

O desenvolvimento mais acelerado das comunicações data da Europa medieval do século XI. Assim como na Grécia antiga, à época imperava uma cultura essencialmente oral, quando os sermões se constituíam um meio essencial à disseminação de informação e a literatura ainda era voltada para um público ouvinte. Inicialmente empregada por papas e reis para uma variedade de propósitos práticos, a cultura escrita se desenvolveu rapidamente nos dois séculos seguintes. Com a crescente demanda por material gráfico, livros e documentos manuscritos passaram a ser produzidos em número cada vez mais elevado.

Nos séculos XV e XVI, com o aperfeiçoamento geralmente creditado à Gutenberg dos tipos móveis, que permitiam a reprodução em escala de textos impressos, tem início o que se convencionou chamar “comunicação de massa”, embora na China, no Japão e na Coréia a impressão já fosse praticada desde o século VIII, se não antes, embora o método utilizado fosse outro - pois idealizado para empregar milhares de ideogramas. Com o desenvolvimento das cidades e a crescente demanda por conteúdos - informações políticas, 
econômicas, produtos culturais diversos -, a prática da impressão gráfica se espalhou pela Europa. Em 1500, havia cerca de 250 locais da Europa com máquinas de impressão instaladas, cuja produção conjunta totalizava 27 mil edições e 13 milhões de livros (Briggs e Burke, 2002, p. 24)

A impressão gráfica custou a penetrar nos mundos cristão ortodoxo e mulçumano, cujas condições sociais e culturais para se disseminar - como uma população laica letrada - não haviam se desenvolvido. Na Europa ocidental, no entanto, se no início da Idade Média havia escassez de livros, no século XVI as publicações e as bibliotecas se multiplicaram. De modo não uniforme, nos séculos seguintes se desenvolveram tanto a produção de conteúdo cultural quanto a atividade de imprensa, embora ainda exploradas de forma rudimentar e geralmente em caráter pré-capitalista, especialmente para a divulgação de conteúdo político e religioso.

Na Reforma e nas guerras religiosas, na Guerra Civil Inglesa e nas revoluções Francesa e Norte-americana do século XVIII, mais do que a atividade de "imprensa” propriamente dita - cuja forma atual só viria a tomar forma no século seguinte -, a produção de livros, brochuras e panfletos procurava disseminar informação e influenciar indivíduos e grupos sociais. Somente no ano de 1789 surgiram 250 jornais na França. Nos EUA, em 1776, já havia 46 jornais. Alguns anos depois, em 1800, 178 semanários e 24 diários circulavam naquele país (Ibidem, p. 103-104).

É nesse contexto histórico, marcado, entre outros fatos, pelo surgimento dos primeiros meios de comunicação de massa, ainda em caráter não-comercial (ou pelo menos não como uma atividade inerente à produção capitalista) que emerge a primeira geração de direitos humanos - os chamados direitos civis e políticos - que podem ser compreendidos tanto como pressuposto quanto como resultado do surgimento da imprensa moderna.

Como pressuposto, porque a publicidade dos ideais liberais por meio dos periódicos (mesmo que rudimentares) foi fundamental para as mobilizações populares e a constituição as alianças entre setores sociais entre os séculos XV e XVIII, como na França 
revolucionária. Como resultado, porque esses marcos históricos impuseram a legitimação dos princípios da liberdade de expressão e da liberdade de iniciativa econômica, dando impulso ao desenvolvimento das técnicas de copiagem necessárias à massificação dos periódicos.

Menos de um século depois, a imprensa e a produção de conteúdo simbólico-cultural passaram a ser elas mesmas importantes atividades econômicas, marcando um ponto de inflexão em sua essência e em sua relação como o mundo. 


\section{5 - LIBERDADE DE EXPRESSÃO: SOB O SIGNO DO LIBERALISMO}

As revoluções do século XVIII, embora comandadas pela burguesia, contaram com a participação ativa das camadas populares, tendo como um dos principais objetivos a conquista da liberdade e a indispensável eliminação dos privilégios da nobreza. República e democracia, então, passam a identificar uma forma de organização política vinculada à idéia de "governo de todos" em lugar do "governo de alguns". Vencedoras tais revoluções, extintos os privilégios da nobreza, convencionou-se denominar democráticos os governos eleitos pelo povo, passando o sufrágio (parcial, depois universal) a fazer parte do aparato jurídico da democracia (Dallari, 2002).

Um dos objetivos mais relevantes da luta contra o absolutismo era justamente o estabelecimento de limites aos detentores do poder político, com a definição de regras que fossem obrigatórias também para os governantes, protegendo os cidadãos das arbitrariedades estatais. Tal objetivo, sintetizado à época na expressão "governo da lei”, pode ser hoje identificado com a existência de limites jurídicos para o exercício do poder político, sendo esta submissão ao Direito, em sentido próprio, indispensável à defesa da dignidade humana, da liberdade e dos direitos humanos. E, justamente por isso, está incorporada à moderna concepção de democracia (Ibidem).

É nesse contexto que emerge a noção moderna de liberdade de expressão -, embora suas raízes filosóficas remetam à Grécia antiga, mais precisamente à Ágora ateniense, onde os que eram reconhecidos como cidadãos se reuniam presencialmente para fazer o uso "livre" da palavra, sem constrangimentos ou impedimentos - derivada da afirmação de outro princípio jurídico, a liberdade de pensamento, ambos vinculados aos ideais do liberalismo, movimento de idéias que percorre autores diferentes entre si, como Locke, Montesquieu, Kant, Adam Smith, Constant, Tocqueville e John Stuart Mill, entre outros.

A liberdade de pensamento é, assim, a origem lógica da liberdade de expressão: 
Não é possível expressar nada se, previamente, não existe pensamento. Por sua vez, a liberdade de expressão dará lugar posteriormente à liberdade de informação. De forma que expressão e informação são as formas de manifestação externa da liberdade de pensamento (Sabau, 2002, p. 16).

No plano jurídico, a história moderna do direito à liberdade de expressão tem origem no Bill of Rights inglês de 1689, apesar das limitações à época ainda impostas à liberdade de imprensa em função do Licensing Act, que determinava, além de outras restrições, a necessidade de licença para a impressão de livros e periódicos. Sua positivação como um direito fundamental ocorreu no bojo da Revolução Francesa, com a Declaração dos Direitos do Homem e do Cidadão de 1789, que em seu artigo XI afirmou que "a livre comunicação dos pensamentos e opiniões é um dos direitos mais preciosos do homem; todo o cidadão pode, pois, falar, escrever e imprimir livremente; salvo a responsabilidade do abuso dessa liberdade nos casos determinados pela lei”.

Dois anos depois, em 1791, a Primeira Emenda à Constituição norte-americana foi ratificada, impedindo que o Congresso dos Estados Unidos legislasse limitando as liberdades fundamentais (dentre as quais a de expressão), afirmando que o parlamento daquele país “não legislará no sentido de estabelecer uma religião, ou proibindo o livre exercício dos cultos; ou cerceando a liberdade de expressão, ou de imprensa, ou o direito do povo se reunir pacificamente, e de dirigir ao governo petições para a reparação de seus agravos".

De forma progressiva, outros instrumentos jurídicos nacionais e, posteriormente, internacionais, passaram a reconhecer a liberdade de expressão como um direito fundamental, princípio que se atrelou de forma inseparável à idéia moderna de democracia e sem o qual se passou a determinar ser impossível a afirmação da dignidade humana.

Há, no entanto, uma variedade e multiplicidade de significados do conceito. "Liberdade" talvez seja uma das palavras com o maior número de interpretações e, mesmo assim, é certamente uma das mais presentes no pensamento moderno. Durante a Guerra Fria, foi utilizada ideologicamente para demarcar duas visões de mundo em conflito e, mesmo 
depois do fim da União Soviética, continua sendo indiscriminadamente empregada para camuflar e/ou proteger os mais diversos tipos de interesse (Lima, V., 2008).

No entanto, à exceção de episódios esporádicos na história, é possível afirmar que o princípio jurídico da liberdade de expressão carregou historicamente em seu bojo a marca da doutrina liberal, sob suas duas principais perspectivas, a econômica e a política. "O liberalismo é, como teoria econômica, fautor da economia de mercado; como teoria política, fautor do Estado que governe o menos possível ou, como se diz hoje, do estado mínimo” (Bobbio, 1987, p. 114). Embora as duas teorias dos limites do poder do Estado (econômica e política) possam ser consideradas independentes - na medida em que não se referem somente à intervenção na esfera econômica, mas se estendem à esfera ético-religiosa ambas possuem raízes históricas comuns e indissociáveis.

Especificamente na linguagem política, são sobretudo duas as acepções mais importantes: as liberdades negativas e positivas. Por liberdade negativa, se entende a situação na qual o sujeito tem a possibilidade de agir sem ser impedido, ou de não agir sem ser obrigado, por outros sujeitos. A liberdade negativa costuma ser também chamada de liberdade como ausência de impedimento ou de constrangimento ${ }^{13}$ (Bobbio, 1996, p. 49). Por liberdade positiva, entende-se a situação na qual um sujeito tem a possibilidade de orientar seu próprio querer no sentido de uma finalidade, de tomar decisões, sem ser determinado pelo querer dos outros. "Essa forma de liberdade é também chamada de autodeterminação, ou, ainda mais propriamente, de autonomia” ${ }^{14}$ (Ibidem, p. 51).

\footnotetext{
${ }^{13}$ Hobbes ilustra essa liberdade nos seguintes termos: “Como os movimentos e ações dos cidadãos nunca são em sua totalidade regulados por lei, e nem podem ser por causa de sua variedade, por isso há necessariamente uma quase infinidade de atos que não são comandados nem proIbidemos, e cada qual pode fazer, livremente. É neles que cada qual goza de liberdade, e é nesse sentido que aqui se toma liberdade, a saber, como a parte do direito natural que é concedida e deixada aos cidadãos pelas leis civis” (De cive, XIII, 15). Locke aponta na mesma direção: "a liberdade dos homens submetidos a um governo consiste (...) na liberdade de seguir sua própria vontade em todas as coisas não prescritas por essa regra; e não estar sujeito à vontade inconstante, incerta, desconhecida e arbitrária de um outro homem” (Segundo Tratado sobre o governo civil, IV, 22).

${ }^{14}$ A definição clássica de liberdade positiva foi dada por Rousseau, para quem a liberdade consiste no fato de o homem, enquanto parte do todo social, como membro do eu comum, não obedecer a outros e sim a si mesmo, no sentido que dá leis a si mesmo e obedece às leis que ele mesmo se deu: “A obediência às leis que prescrevemos para nós é a liberdade” (Contrato Social, I, 8). Este conceito de liberdade foi retomado por Kant, no qual, porém, também se encontra o conceito de liberdade negativa. No ensaio Para a paz perpétua, Kant especifica que "é melhor definir minha liberdade exterior (isto é, jurídica) como a faculdade de só obedecer às leis externas às quais pude dar meu assentimento”.
} 
As duas formas de liberdade podem ser distinguidas também com base no diferente sujeito histórico que é portador de uma e de outra. Quando tomamos em consideração a liberdade negativa, o sujeito histórico a que nos referimos é geralmente o indivíduo singular; já quando o objeto de nosso discurso é a liberdade positiva, o sujeito histórico ao qual ela é habitualmente referida é um ente coletivo. As liberdades civis, protótipos das liberdades negativas, são liberdades individuais, isto é, inerentes ao indivíduo singular: são historicamente o produto das lutas pela defesa do indivíduo, considerado ou como pessoa moral (e, portanto, tendo um valor em si mesmo) ou como sujeito de relações econômicas, contra a intromissão de entes coletivos com a Igreja e o Estado.

\section{A idéia moderna de liberdade de expressão deriva justamente do conceito de liberdade negativa: considera-se, desde então e até hoje, que um cidadão desfruta de uma situação de liberdade quando pode expressar suas próprias opiniões sem incorrer nos rigores da censura estatal.}

O processo de positivação da liberdade de expressão, desse modo, está intimamente ligado ao surgimento do Estado liberal e à constituição da burguesia enquanto força política hegemônica, no qual tal liberdade - inversamente ao seu significado para os antigos ${ }^{15}$ constitui-se prioritariamente como uma liberdade negativa do Estado face ao indivíduo.

Vinculada ao direito fundamental de liberdade de expressão - e no mesmo contexto, a partir da demanda pelo fim dos privilégios para a reprodução de livros e periódicos - surge a demanda pelo reconhecimento da liberdade de imprensa, consagrada na Primeira Emenda à Constituição norte-americana. Observa Dallari (2001) que a liberdade de imprensa "foi incluída entre os dogmas do Estado liberal burguês. Desde o século 18, ela é reconhecida como necessária para a preservação da liberdade, mesmo quando ainda não se poderia

\footnotetext{
${ }^{15}$ Como alerta Comparato, a democracia moderna difere da demokratia grega. "Nesta [na democracia grega], como explicou Aristóteles, o poder supremo (kyrion) pertence ao demos, que o exerce diretamente e nunca por meio de representantes. Ora, o demos ateniense é composto, em sua grande maioria, por pequenos camponeses e artesãos, de grupos de baixo poder econômico. É por isso que, no pensamento político grego, a democracia representa a exata antítese da oligarquia, em que o poder político supremo pertence à classe proprietária” (2003, p. 50).
} 
prever o extraordinário avanço tecnológico dos meios de comunicação e a tremenda influência, positiva ou negativa, que eles poderiam exercer”.

A liberdade de imprensa, deste modo, pode ser considerada a materialização jurídica do direito ao exercício comercial da atividade de imprensa, não se confundindo com o direito fundamental do indivíduo à liberdade de expressão, embora manifestações contemporâneas - como se evidenciará em capítulos posteriores - se apóiem nesta pretensa equivalência de significado.

Em síntese, o contexto no qual emergiram contribui para determinar os limites impostos ao conceito de liberdade de expressão após o surgimento da comunicação de massa. O liberalismo, com uma das mãos, a partir das duas revoluções do final do século XVIII, permitiu o reconhecimento dos direitos humanos civis e políticos, assim como a reinstituição da legitimidade democrática; com a outra mão, ao criar condições para o desenvolvimento capitalista, permitiu a ascensão de um modelo necessariamente baseado na acumulação de poucos e na exclusão da maioria.

E, se em outras áreas de direitos humanos a organização da classe trabalhadora culminou com o posterior reconhecimento de direitos sociais e econômicos, as comunicações não foram objeto de lutas sociais anticapitalistas, o que acabou por determinar, em função da dinâmica imposta pelo desenvolvimento da comunicação social enquanto atividade econômica privada, a vigência e a posterior radicalização da compreensão do conceito de liberdade de expressão como uma liberdade negativa.

Estas afirmativas, evidentemente, não significam que a origem filosófica liberal referendaria a tese que afirma ser o Estado o único obstáculo à liberdade de expressão. Pelo contrário: um dos ícones do liberalismo, John Stuart Mill, afirmava ser o poder dos "costumes" e da uniformidade do pensamento a verdadeira ameaça à individualidade e à pluralidade. Em Sobre a Liberdade (On Liberty), ensaio rotineiramente invocado como um dos pilares da defesa da liberdade de expressão e da liberdade de imprensa, Mill lembra o perigo da "tirania da maioria": a sociedade - e não o governo - pode passar a fazer as vezes 
do tirano. Mill aborda de forma veemente a questão do "jugo da opinião" (the yoke of opinion) e do controle que ela exerce sobre o indivíduo e suas conseqüências, incluindo a crítica aos jornais e seus jornalistas na formação das opiniões.

Vale a longa citação, lembrando que o texto se refere à Inglaterra vitoriana de meados do século 19:

\footnotetext{
"Nos dias de hoje, os indivíduos estão perdidos na multidão. Em política, é quase uma trivialidade dizer que agora a opinião pública governa o mundo. O único poder que merece esse nome é o das massas e o dos governos, que constituem o órgão das tendências e instintos da massa. Isso vale tanto para as relações morais e sociais da vida privada, como para as transações públicas. O que se chama de opinião pública nem sempre é a opinião da mesma espécie de público: nos Estados Unidos, o público é toda a população branca; na Inglaterra, principalmente a classe média. Porém, formam sempre uma massa, isto é, uma mediocridade coletiva. E o que é uma novidade ainda maior, a massa não recebe suas opiniões de dignitários na Igreja e no Estado, de líderes manifestos ou de livros. O que pensam é criado por homens muito semelhantes a eles mesmos, os quais se dirigem a eles ou falam em seu nome, impulsivamente, por meio dos jornais" (Mill, 2000a, p. 101 - grifos nossos).
}

Ou seja, no liberalismo de Mill é possível colher sinais inequívocos de crítica à reprodução discursiva não representativa da diversidade social, por meio da apropriação privilegiada e, portanto, desigual - dos meios de comunicação de massa (no caso os jornais), sendo inapropriado determinar que Mill e todos seus colegas liberais (ou mesmo como John Milton, ao lado de Mill o mais comumente invocado na defesa da liberdade de expressão), partilhariam das teses que defendem a abstenção absoluta do Estado na regulação do campo da comunicação.

\section{1 - O direito à informação e a consolidação do sujeito passivo}

Mais de 150 anos depois das revoluções do século XVIII, a Declaração Universal dos Direitos Humanos de 1948, em seu artigo 19, afirmou que "todo indivíduo tem direito à 
liberdade de opinião e de expressão; este direito inclui a liberdade de, sem interferência, ter opiniões e de procurar, receber e transmitir informações e idéias por quaisquer meios, independentemente de fronteiras”. Vinte anos mais tarde, em 1969, a Convenção Americana de Direitos Humanos (Pacto de San José da Costa Rica), em seu artigo 13, apontou na mesma direção: "Toda pessoa tem o direito à liberdade de pensamento e de expressão. Esse direito inclui a liberdade de procurar, receber e difundir informações e idéias de qualquer natureza, sem considerações de fronteiras, verbalmente ou por escrito, ou em forma impressa ou artística, ou por qualquer meio de sua escolha”.

No ano 2000, a Organização dos Estados Americanos (OEA) elaborou uma Declaração de Princípios Sobre a Liberdade de Expressão. Em seu primeiro artigo, a Declaração inova ao relacionar liberdade de expressão e democracia, afirmando que "a liberdade de expressão, em todas as suas formas e manifestações, é um direito fundamental e inalienável, inerente a todas as pessoas. É, ademais, um requisito indispensável para a própria existência de uma sociedade democrática”.

Nacionalmente, a liberdade de expressão possui status de garantia constitucional fundamental, consistindo basicamente num conjunto de direitos, formas, processos e veículos, que possibilitam a coordenação desembaraçada da criação, expressão e difusão do pensamento e da informação. É o que se pode extrair dos incisos IV, V, IX, XII e XIV do art. $5^{\circ}$ combinados com os artigos 220 a 224 da Constituição.

A liberdade de expressão, dessa forma, foi sendo progressivamente incorporada aos marcos jurídicos nacionais e internacionais. E, simultaneamente, este processo foi acompanhado pelo surgimento do direito à informação enquanto um segundo princípio jurídico aplicável ao campo da comunicação social.

Dentre as primeiras manifestações que buscam apontar a necessidade de reconhecimento do novo principio jurídico aplicável ao campo da comunicação se destacam a de Paul-Louis Bret. Em 1946, o jornalista francês apontou que o "direito ao fato" demandava a positivação do direito à informação (Ariente, 2008). 
Como lembras Desmond Fischer (1982), os horrores da Segunda Guerra tornaram evidente o poder do uso instrumental dos meios de comunicação, induzindo os debates em torno da Carta da ONU ao reconhecimento de que, além do direito de livre expressão, os indivíduos eram titulares também do direito de ser informados corretamente dos fatos pertinentes ao conjunto da sociedade na qual se insere.

Como decorrência, dois anos depois, em 1948, a Carta das Nações Unidas consagrou que da liberdade de expressão decorria também o "direito de procurar, receber e difundir" informações.

A Constituição Federal de 1988, além do reconhecimento do direito à liberdade de expressão, também avançou rumo ao reconhecimento do direito à informação, assegurando “a todos o acesso à informação” (art. 5, XIV).

De forma geral, o direito à informação é percebido como "o direito de comunicar e receber livremente informação sobre fatos, ou talvez mais restringidamente, sobre fatos que se podem considerar noticiáveis” (Farias, 2000, p. 165). Ou, como aponta Eugênio Bucci, é o direito do indivíduo de "ser informado de modo independente, recebendo os dados necessários para que forme a sua opinião” (Bucci, 2004, p. 244).

Outros autores, como Melo, J. M. (1986), Ferreira (1997) e Freitas Nobre (1967) também se detiveram sobre o significado e implicações do direito à informação. A leitura hegemônica aponta ser o direito à informação o direito a receber informações, efetivado na medida em que liberdade de expressão e a liberdade de imprensa podem ser exercidas, embora a Declaração Universal dos Direitos Humanos afirme serem os indivíduos portadores do “direito a difundir” informações, o que poderia justificar interpretação mais ampla.

O reconhecimento desse direito no ordenamento jurídico nacional incorporou essa limitação, consagrando o termo “acesso à informação", que elimina outro entendimento que 
não o de ser o cidadão titular do direito a receber e buscar informações, mais do que ter as suas mensagens recebidas, impondo ao titular do direito uma condição passiva frente aos produtores e difusores de informação.

Outra característica relevante do direito à informação é o fato de seu conteúdo ser exclusivamente a “informação jornalística”. Não se aplica, geralmente, aos outros conteúdos simbólicos e culturais que fazem parte do cotidiano das sociedades. Ou seja, é atribuível somente ao conteúdo noticioso produzido e recebido pelos indivíduos.

Apesar deste recorte ligado à prática do jornalismo e da imposição de uma condição passiva ao titular do direito à informação, é importante notar a existência de uma trajetória lógica no desenvolvimento dos direitos ligados ao campo da comunicação. Primeiro, surgiu a liberdade de pensamento, relativa à esfera eminentemente privada do cidadão. Em seguida, foi consagrada a liberdade de expressão e, como decorrência, a liberdade de imprensa. Posteriormente é reconhecido o direito à informação, que determina o indivíduo como partícipe de uma sociedade que racionalmente busca soluções para si e para a sociedade. Tem-se, portanto, que à dimensão individualista-liberal foi acrescida uma outra dimensão de natureza coletiva, a de que a liberdade de expressão e o direito à informação contribuem para a “formação da opinião pública pluralista, essa cada vez mais essencial para o funcionamento dos regimes democráticos” (Farias, 2000, p. 163).

Evidentemente, as qualidades da informação - se plural ou fruto de monopólio, se verdadeira ou fruto de má fé, se produzida sob o prisma do interesse público ou privado são atributos decorrentes do direito à informação, e certamente devem ser considerados como parte de seu escopo, mas estes elementos não alteram o caráter essencialmente passivo do titular do direito, seja ele o indivíduo ou um grupo social determinado. 


\section{6 - A APROPRIAÇÃO DAS TÉCNICAS E DOS FLUXOS}

No século XIX, os empresários descobriram o potencial comercial do jornalismo como negócio lucrativo e surgiram as primeiras publicações cujo fim prioritário passou a ser gerar ganhos financeiros aos seus proprietários e acionistas. O The Guardian, um dos jornais mais vendidos do Reino Unido até hoje, surgiu em 1821. Nos Estados Unidos, em 1833, foi fundado o New York Sun, primeiro jornal “popular”, vendido a um centavo de dólar (Melo, P., 2005). Joseph Pulitzer e William Randolph Hearst, que nesta época criaram grandes jornais destinados à venda em massa, estão entre as personagens desta inflexão do caráter da imprensa ${ }^{16}$.

O desenvolvimento capitalista - estimulado pela Revolução Industrial - também deu grande impulso às telecomunicações. À época, o telégrafo elétrico, cujas primeiras linhas estáveis datam de 1850, tinha como principais clientes bolsas de valores e comerciantes, que ocupavam 80\% do tráfego na Inglaterra e 72\% na França (Dantas, 2002, p. 107). Nas décadas seguintes, o telégrafo amadureceu com o capital financeiro, maior indutor das pesquisas científicas e técnicas que determinaram sua evolução. Nos países líderes destes processos - onde as tecnologias e as empresas que as exploravam comercialmente nasceram -, a expansão das redes de telecomunicações atendeu prioritariamente aos objetivos estratégicos de cada Estado e os interesses maiores do conjunto da sociedade determinaram o estímulo ao seu desenvolvimento econômico e social.

Já os países periféricos - incluindo, evidentemente, o Brasil - não desenvolveram sistemas de telecomunicações próprios e autônomos, conseqüência da subordinação tecnológica e industrial a que foram submetidos. As infraestruturas de transporte de informação nesses países serviram, basicamente, à inserção internacional de suas economias, fonte de matérias-primas e mão-de-obra barata para os países centrais. Secundariamente, forneceram redes telegráficas ou telefônicas para as classes mais ricas (Ibidem, p. 129).

\footnotetext{
${ }^{16}$ Antes disso, no século XVI, uma única família já dominava o sistema postal europeu, explorando-o comercialmente a partir de uma tabela de preços. O termo “táxi”, de uso internacional, deriva justamente do nome dessa família, Tassis (Briggs e Burke, 2002).
} 
Enquanto isso, nos países centrais do capitalismo, desenvolviam-se modelos institucionais que perduraram praticamente meio século, de 1930 a 1980, baseados nos interesses internos de cada uma das nações. Nos EUA, por exemplo, optou-se por um monopólio privado nacional (concedido à $A T \& T$ ), garantindo que, em 1940, enquanto o telefone ainda engatinhava no Brasil, quase 100\% dos lares norte-americanos já estivessem conectados à rede telefônica. Já nos países europeus ocidentais, a herança dos correios e telégrafos levou ao surgimento das também monopolistas PTTs (Postal, Telegraph and Telephone), autarquias governamentais que regulavam e operavam os sistemas de comunicação.

A partir da expansão mundial das redes de telecomunicações, surgiram as primeiras agências de notícias: a francesa Havas (hoje France Press), a britânica Reuters, a alemã Wolff, as norte-americanas AP e UPI. Além de produzirem noticiários jornalísticos - com determinantes conseqüências políticas, sociais e culturais -, também coletavam e difundiam informações econômico-financeiras para banqueiros e comerciantes e eram, também, um instrumento de propaganda ideológica das grandes potências em suas disputas internacionais (Rodrigues, 2009).

Assim como nas telecomunicações, modelos distintos se estabeleceram na radiodifusão nos EUA e da Europa. Enquanto nos EUA vingou o modelo privado, com três grandes grupos nacionais regulados de forma a impedir monopólios cruzados e em cada uma das mídias (rádio, televisão, jornal), na Europa Ocidental, no Canadá, na Austrália e no Japão consolidou-se o modelo de serviço público, com a exploração do rádio e da televisão reservada a empresas estatais dotadas de relativa independência dos governos, onde o financiamento dos sistemas ainda hoje provém prioritariamente do pagamento de taxas diretamente pelos usuários ${ }^{17}$.

Especialmente após a Segunda Guerra, se radicaliza o processo de expansão da Indústria Cultural norte-americana. Capitaneadas pelas associações da indústria fonográfica e da

\footnotetext{
${ }^{17}$ É o caso da BBC no Reino Unido, da NHK no Japão, da France Televisións e Rádio France na França, da RAI na Itália, da RTVE e FORTA na Espanha, da ZDF e RD na Alemanha, da RTP e RDP em Portugal, da CBC e SRC no Canadá, e da ABC na Austrália. O monopólio público sobre a radiodifusão nesses e em outros países só foi quebrado pela onda neoliberal da década de 1980, quando emissoras comerciais também passaram a explorar o serviço (Intervozes, 2009).
} 
indústria de filmes de longa-metragens, os conteúdos produzidos pelos EUA se alastraram pelo mundo, tornando este setor da economia - de produtos audiovisuais - o mais importante na balança comercial norte-americana, superando a economia bélica (Gindre, 2007). Esse processo atingiu em cheio o Brasil, que desde então é um importante consumidor dos produtos da indústria cultural norte-americana, no cinema, na música, nos programas televisivos e, mas recentemente, nos portais de busca na Internet, nos serviços de mensagens eletrônicas e nas chamadas redes sociais.

\section{1 - As telecomunicações nacionais}

O telégrafo elétrico foi introduzido experimentalmente no Brasil em 1852 por um serviço telegráfico estatal criado e dirigido por Guilherme Schüch, o Barão de Capanema. A primeira linha de uso efetivo passou a funcionar três anos depois, em 1855, sendo instalada entre as cidades do Rio de Janeiro e Petrópolis ${ }^{18}$. Em dez anos, costeando o litoral por terra, as linhas chegaram a Porto Alegre. Em 1874, também pelo litoral, completou-se a ligação do Rio de Janeiro a Recife. Em 1884, o telégrafo chegou a São Luis e, dois anos depois, a Belém (Pareto Neto, 1976).

No mesmo período, em 1872, o Visconde de Mauá, pioneiro na exploração de diversas atividades econômicas em terras brasileiras, obteve licença para ligar, por cabo submarino, o Brasil a Portugal e suas colônias. O empreendimento naufragou, e Mauá acabou por repassar, sem custos, a concessão que havia recebido do governo imperial à companhia britânica Telegraph Construction Maitenance Co. À época, a Telegraph incorporou a concessão para a instalação de outros cabos submarinos outorgada pelo governo pouco antes ao engenheiro inglês Charles Bright.

Neste mesmo ano de 1872, o governo imperial brasileiro confirmou a empresa britânica como única exploradora dos serviços de telecomunicações internacionais no Brasil por 60 anos, sendo que nos 40 anos seguintes a exploração seria feita sem exclusividade, mas com

\footnotetext{
${ }^{18}$ É desta fase, mais precisamente de 1860, o primeiro diploma legal de que se tem registro sobre as comunicações brasileiras, o Decreto Imperial 2.614 de 11 de julho de 1860, que estabelecia e organizava a exploração de telégrafos.
} 
vantagens fiscais. Dois anos depois, a Telegraph transferiu seus direitos para a também britânica Western and Brazilian Telegraph Co. que, até 1973, em função dos privilégios conquistados um século antes, controlou amplamente as telecomunicações de longa distância no Brasil (Dantas, 2002).

No início do século XX, em 1907, o grupo anglo-canadense Light \& Power, que explorava os serviços de eletricidade e transporte urbano (os bondes) no Rio de Janeiro, criou a Companhia Telefônica Brasileira (CTB). Por meio dela, dotou pela primeira vez a capital da República brasileira de um serviço telefônico, expandindo nos anos seguintes as linhas para São Paulo, Belo Horizonte e outras cidades da região Sudeste.

Na expansão de sua rede, a CTB concentrou as operações onde era mais intenso o tráfego comercial e nos bairros ocupados por famílias ricas e de classe média, desinteressada que estava em atuar no mercado de longa distância, já dominado pela Western. Esta manteve sua posição dominante mesmo depois de expirado seu privilégio monopolista, isso porque, enquanto as empresas estrangeiras interessadas em entrar no mercado eram obrigadas a pagar altas taxas ao Departamento de Correios e Telégrafos, a Western foi "liberada” de tal obrigação, pois já à época exercia grande influência sobre os funcionários de alto escalão da República (Pareto Neto, 1976).

Esta primeira fase do desenvolvimento das telecomunicações no Brasil é extremamente didática. Ela nos revela ter havido, no passado, um duopólio, compartilhado por um Estado semicolonial e um poderoso grupo empresarial estrangeiro. O governo nacional, com poucos recursos e administradores subservientes ou atrelados aos interesses internacionais, cuidava das comunicações interioranas. As ligações entre Rio, São Paulo, Santos e Belo Horizonte - e destas cidades para o exterior - eram feitas pela Western e seus principais sócios ${ }^{19}$. Para a economia brasileira, de essência exportadora e desprovida de projeto de desenvolvimento interno, era

\footnotetext{
19 “Podia-se falar de casa, pelo telefone, do Rio e de São Paulo, para Paris, Londres ou Nova Iorque, porém não se podia falar para Porto Alegre, Salvador ou Recife”, lembra Pareto Neto (1976, p. 38).
} 
mais decisivo se comunicar com os centros capitalistas do mundo do que com a periferia pobre do Brasil.

No Brasil, como nos demais países dependentes e subordinados às estratégias industriais e financeiras de corporações empresariais estrangeiras, as telecomunicações foram condenadas a enorme atraso, situação recuperada parcialmente pelo esforço desenvolvimentista realizado a partir de 1965.

\section{2 - O suspiro desenvolvimentista}

O CBT - Código Brasileiro de Telecomunicações, aprovado e sancionado em 1962, nasceu em meio a crescentes manifestações de impaciência com os serviços de telecomunicação prestados no país pelas empresas estrangeiras. No Rio Grande do Sul, o governador Leonel Brizola estatizou a Companhia Telefônica Rio-Grandense, controlada pela norte-americana ITT. No então Estado da Guanabara, o governador Carlos Lacerda criou a Cetel, com a intenção de levar linhas telefônicas aos bairros da periferia da cidade, desprezados pela $\mathrm{CTB}^{20}$. Em outras cidades brasileiras, o serviço telefônico era explorado diretamente poderes municipais, exceto nos estados do Rio Grande do Sul, Paraná e Pernambuco, inteiramente dominados pela ITT. À época, havia cerca de 900 companhias telefônicas espalhadas por todo o país, mas apenas um telefone para cada cem habitantes (Tome, 1991).

A partir de 1947, os radiodifusores passaram pressionar o Congresso Nacional para a criação de um Código Nacional de Radiodifusão capaz de orientar juridicamente um cada vez mais complexo sistema de estações de rádio - ao qual se somaria, logo em seguida, a televisão - assentado sobre bases de exploração comercial, na forma de empresas lucrativas. O pleito junto ao Legislativo se manteve até 1957, quando seu escopo, por conveniência, foi estendido para os serviços de telecomunicações e culminou na aprovação do Código Brasileiro de Telecomunicações, em 1962. Neste contexto, apesar de se configurarem como serviços aparentemente distintos, as telecomunicações e a radiodifusão passaram ambas a

\footnotetext{
${ }^{20}$ Apesar de deter concessões somente para os municípios da Região Sudeste, a CTB operava 2/3 de todas as linhas telefônicas do país (Tome, 1991)
} 
ser regulamentadas pelo CBT - nome dado à Lei $\mathrm{n}^{0} 4.117 / 62$-, fato que perdurou até a promulgação da Lei Geral de Telecomunicações na década de 1990.

\section{Foi nas discussões acerca da aprovação do CBT, que surgiu a Associação Brasileira de} Emissoras de Rádio e Televisão (ABERT). Na ocasião, devido ao já atuante lobby das emissoras, o Congresso Nacional derrubou todos os 52 vetos que o presidente João Goulart havia imposto ao novo Código, em fato até hoje singular na história brasileira.

Entre as grandes novidades do Código estava a criação do Contel (Conselho Nacional de Telecomunicações), organismo de regulação centralizado no Poder Executivo, com modelo diverso do adotado em países da Europa Ocidental e nos EUA, onde a Federal Communications Comission (FFC) criada em 1934 mantém-se eqüidistante dos poderes Executivo e Legislativo. Ao Contel coube regular as telecomunicações e a radiodifusão também chamada de Comunicação Social Eletrônica -, excluindo o cinema, cuja regulação foi historicamente vinculada ao Ministério da Justiça. O Contel, contudo, foi extinto pelos militares em 1967, sendo substituído pelo Ministério das Comunicações, órgão que desde a sua criação atuou sob forte influência dos radiodifusores.

Outra determinação do CBT foi a formação de uma empresa estatal para instalar e operar troncos de comunicação de longa distância. Dessa forma, três anos após a entrada em vigor do Código (no ano seguinte ao golpe militar), em 1965, o governo brasileiro criou a Embratel, dando início à construção de uma rede nacional de troncos de microondas. Como resultado, em cinco anos - entre 1967 e 1972 -, a Embratel conectou as principais cidades das cinco regiões do país, permitindo, por meio da discagem direta à distância (o DDD), a ligação entre os municípios brasileiros mais importantes (Rodrigues, 2009).

Também foi importante o papel da Embratel na expansão da rede de Telex. Embora o sistema esteja hoje em desuso, o Telex representou um avanço significativo em relação ao telégrafo (ficando a meio caminho do atual fax), em especial para as grandes empresas brasileiras jornalísticas, que, ao terem os meios técnicos para montar agências próprias de 
notícias, passaram a se relacionar com a imprensa regional de modo semelhante à relação estabelecida entre as agências internacionais e a imprensa dos países periféricos ${ }^{21}$.

Este processo de surgimento das agências de notícias, assim como o investimento na formação de uma grande emissora nacional de televisão contribuíram, de modo não desprezível, ao oligopólio que domina e controla a comunicação social no Brasil e que conduziu também à formação de monopólios e oligopólios regionais de informação.

Nas telecomunicações, o programa implementado pelo governo, em seus primeiros anos, foi um sucesso inegável: entre 1972 e 1975, o número de linhas passou de 1,4 milhão para 2,2 milhões. Nos três anos seguintes, chegou a 4,6 milhões. O incremento anual do número de linhas realizou-se, nesses anos, a taxas sempre superiores a 15\%, atingindo 32\% em 1976. De 1970 a 1990, enquanto a população brasileira cresceu 50\% e o PIB 90\%, a planta instalada de terminais telefônicos do Sistema Telebrás cresceu 500\% (Ministério das Comunicações, 1996).

\section{3 - Reforma do Estado: a privatização das telecomunicações}

Durante a década de 1990, os países da Europa, América Latina e África passaram por processos de desregulamentação e liberalização de setores estratégicos. Ao modificarem suas legislações e suprimirem mecanismos que protegiam a economia, estes países abriram as portas para a privatização de empresas estatais e a entrada de capital internacional. Neste contexto, desde 1980, foram privatizadas aproximadamente 6.832 empresas públicas em mais de 80 países (Becerra, 2003). Organismos internacionais - como o Fundo Monetário Internacional, o Banco Mundial e a Organização Mundial do Comércio -, por interferência direta ou indireta das nações hegemônicas, passaram a determinar uma nova política mundial alinhada aos objetivos e metas de globalização da economia. Um dos principais

\footnotetext{
${ }^{21}$ Este processo de surgimento das agências de notícias, assim como o investimento na formação de uma grande emissora nacional de televisão contribuíram, de modo não desprezível, ao oligopólio que domina e controla a comunicação social no Brasil e que conduziu também à formação de monopólios e oligopólios regionais de informação.
} 
alvos dessa universalização neoliberal ${ }^{22}$ foi o setor das comunicações, especialmente as empresas estatais de telecomunicações, que detinham em seus países o monopólio desses mercados.

Em meio às principais justificativas para esse processo de desregulamentação, foram apresentados os argumentos da ineficiência das empresas monopolistas, da qual seria sinal a pretensa insatisfação dos usuários do serviço público, e da incapacidade financeira e gerencial do Estado, mesmo em setores estratégicos. Segundo o discurso neoliberal, seriam necessários vultosos investimentos e a introdução de “competência” nestes setores, só alcançáveis a partir da quebra dos monopólios estatais, das privatizações, da implantação das regras de livre mercado e da abertura ao capital estrangeiro (Rodrigues, 2008).

Como a mudança no modelo do setor, a prestação dos serviços de telecomunicações deixou de ser feita por empresas estatais, e passou a ser realizada por empresas privadas, em um mercado cujas regras e a relação com o consumidor são fiscalizadas pelo órgão regulador, a Agência Nacional de Telecomunicações (ANATEL). O objetivo do novo modelo seria obter o acesso à universalização das telecomunicações (basicamente, ao sistema de telefonia fixa), por meio de concessionárias que operariam em um mercado concorrencial e competitivo.

No Brasil, a privatização das telecomunicações, com o conseqüente desmonte do Sistema Telebrás, remonta ao governo Collor de Mello, a partir da privatização da Cosipa e da CSN. Nas comunicações, já neste período, foi aberta a exploração dos serviços postais, com as franquias de postos dos Correios. Com a aprovação da Lei das Concessões, o governo Fernando Henrique Cardoso deu novo e decisivo impulso ao processo de quebra de monopólios estatais e à privatização de empresas públicas, sob a justificativa adicional de

\footnotetext{
${ }^{22}$ Entende-se o neoliberalismo na acepção traduzida de forma didática por Octavio Ianni: “O neoliberalismo compreende a liberação crescente e generalizada das atividades econômicas, compreendendo a produção, distribuição, troca e consumo. Funda-se no reconhecimento da primazia das liberdades relativas às atividades econômicas como pré-requisito e fundamento da organização e funcionamento das mais diversas formas de sociabilidade; compreendendo não só as empresas, corporações e conglomerados, mas também as mais diferentes instituições sociais” (2004, p. 313-314).
} 
arrecadar recursos para o pagamento da dívida da União, cuja redução seria necessária para a "focalização" dos investimentos em áreas sociais.

Para levar a cabo, nas telecomunicações, seu projeto de reforma do Estado, o governo FHC propôs e o Congresso Nacional aprovou, também em 1995, a Emenda Constitucional $n^{0} 8$, alterando o inciso XI do artigo 21 da Constituição Federal de 1988. Com a mudança, foi possível a abertura ao capital privado da exploração dos serviços públicos de telecomunicações, pondo fim a um monopólio que começara com o regime militar em 1972 e que se tornara item constitucional em $1985^{23}$.

A Proposta de Emenda Constitucional que previa o fim do monopólio estatal das telecomunicações foi encaminhada ao Congresso Nacional em 15 de fevereiro de 1995, como parte de um amplo elenco de reformas da ordem econômica: o fim do monopólio do petróleo, do gás canalizado, da exploração do subsolo e da navegação de cabotagem, além de cessar a distinção entre empresa brasileira de capital nacional e de capital estrangeiro. Nas telecomunicações, a alteração suprimiu, no inciso XI do art. 21, a expressão “a empresas sob controle estatal”, permitindo, com isso, a outorga a empresas privadas do direito de exploração dos serviços públicos de telecomunicações. Não modificou-se, assim, as regras para os serviços de radiodifusão, tratados pelo inciso XII.

A nova redação trouxe ainda uma importante alteração, justamente a separação entre os serviços de telecomunicações e os serviços de radiodifusão, até então unidos constitucionalmente. Ao revogar a expressão “e demais serviços de telecomunicações”, determinou-se o fim do vínculo legal entre as telecomunicações - como telefonia, transmissão de dados e, mesmo, a televisão por assinatura - e a radiodifusão. Assim, as futuras regulamentações exigidas para as telecomunicações - inclusive a criação do órgão regulador - não teriam qualquer ingerência efetiva sobre o rádio e a televisão abertos.

\footnotetext{
${ }^{23}$ A Emenda Constitucional no 27, de novembro de 1985, somente confirmou uma situação que, de fato, já existia desde 1972.
} 
Tal modificação não constava do projeto original e deixou clara uma dupla convergência de interesses: de um lado, o da ABERT, a quem interessava livrar a radiodifusão de qualquer modificação legal, sobretudo a submissão a um órgão regulador autônomo; de outro, o do governo federal, que queria impor seu novo modelo institucional para as telecomunicações, privado e pretensamente em regime de competição, e para isso não poderia enfrentar os interesses do mais forte grupo de pressão em ação no Congresso Nacional - o dos proprietários de emissoras de rádio e televisão. Tratou-se, portanto, de uma elaboração política, conjuntural, datada e identificada com os interesses que a motivaram: resultou de uma estratégia, urdida na reforma constitucional de 1995 pelo empresariado de radiodifusão para escapar à jurisdição do novo órgão regulador que foi concebido para atuar sobre o conjunto das comunicações (Herz, 1997).

O resultado prático da privatização das telecomunicações se revela em números. Em todos os serviços disponíveis aos usuários, os consumidores nacionais estão entre os que mais caro pagam pelo acesso aos serviços (Rodrigues, 2008).

\begin{tabular}{|c|c|c|c|c|c|c|}
\hline Classe Social & $\begin{array}{l}\text { TV ABERTA } \\
\text { (basedomiclios) }\end{array}$ & $\begin{array}{l}\text { TELFFoNAF FIXA } \\
\text { (base domiclios) }\end{array}$ & 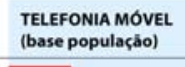 & $\begin{array}{l}\text { TV ASSINATURA } \\
\text { (base domicilios) }\end{array}$ & $\begin{array}{l}\text { INTERNET } \\
\text { (base domiclios) }\end{array}$ & $\begin{array}{l}\text { BANDA LARGA } \\
\text { (base domicilios }\end{array}$ \\
\hline A & 99 & 99 & 83 & 70 & 82 & 64 \\
\hline B & 99 & 90 & 77 & 23 & 50 & 26 \\
\hline$C$ & 97 & 70 & 53 & 5 & 16 & 7 \\
\hline$D / E$ & 85 & 40 & 28 & 1 & 2 & 0,8 \\
\hline
\end{tabular}

Penetração dos serviços de comunicação por Classe de Renda

Como revela o quadro acima, o acesso à Internet é sintomático da desigualdade de acesso aos serviços de comunicação. Apesar de ser objeto de políticas públicas municipais, estaduais e federais há quase uma década, o percentual de pessoas que utilizaram a Internet 
no Brasil, em 2008, era de aproximadamente 38\% da população, considerando todas as modalidades de acesso residencial e não residencial, inclusive as de acesso público. $\mathrm{O}$ número de domicílios conectados não passa de 18\%, sendo que $31 \%$ destas residências ainda utilizava a velha conexão discada para acesso à rede mundial de computadores. A situação se agrava nos recortes feitos a partir de critérios sócio-econômicos: 84\% dos indivíduos situados nas classes $\mathrm{C}$ e D nunca acessou a rede; na classe $\mathrm{C}$ o índice chega a $55 \%{ }^{24}$.

A enorme disparidade sócio-econômica se reproduz entre os que dispõem de acesso domiciliar. Nas classes D e E, somente 1\% das residências detém algum tipo de acesso, subindo para um ainda baixo número de $16 \%$ na classe C. Na ponta da pirâmide, no entanto, a classe A vive a situação inversa, tendo 91\% de seus domicílios atendidos por alguma forma de conexão à rede ${ }^{25}$.

Assim, é possível afirmar que, ao contrário do senso comum difundido nos últimos anos, a privatização das telecomunicações na década de 1990 não resultou nos benefícios apregoados, tanto em relação à universalização dos serviços quanto em relação à competição e à modicidade tarifária, tendo os dois primeiros objetivos (universalização e competição) esbarrado principalmente na renda média do consumidor brasileiro, ou, em outras palavras, atingido os seus limites de mercado. $\mathrm{O}$ modelo urgido da Reforma do Estado brasileiro desconsiderou esta questão fundamental, sem a qual este ou qualquer outro modelo deixaria de atingir os resultados desejados. Sem renda, os cidadãos colocam-se sob o dilema de escolher quais serviços de comunicações terão acesso e, em geral, além da televisão e do rádio, estes mesmos cidadãos têm optado pela telefonia móvel pré-paga (Rodrigues, 2008).

\footnotetext{
${ }^{24}$ TICs Domicílios, 2008. <http://www.cetic.br/usuarios/tic/2008-total-brasil/index.htm>

${ }^{25}$ Segundo relatório da Conferência das Nações Unidas para Comércio e Desenvolvimento, o Brasil ocupava em 2007 a $72^{a}$ posição no ranking mundial de penetração da Internet, com níveis comparáveis a outros países da América Latina, como o Chile (66 $)$, Argentina (78 $)$ e México $\left(79^{a}\right)$. No ranking de penetração de banda larga, o Brasil frequentou o $58^{\circ}$ em 110 países, atrás do Chile $\left(38^{\circ}\right)$ e do México $\left(57^{\circ}\right)$.
} 


\section{4 - A hegemonia da radiodifusão privada-comercial}

A história da radiodifusão brasileira tem início em 7 de setembro de 1922, primeiro centenário da Independência do Brasil, mas a instalação oficial da primeira emissora de rádio aconteceu somente no ano seguinte, em 1923, com a criação, por Roquete Pinto e Henry Morize, da Rádio Sociedade do Rio de Janeiro, cujo modelo de exploração era baseado em mensalidades pagas pelos detentores de receptores. A programação da emissora - que posteriormente foi doada ao governo federal e existe até hoje sob o nome de Rádio MEC - era voltada à elite carioca, com programação composta de óperas, recitais de poesia e concertos. Os anúncios publicitários eram proibidos (Dantas, 2002).

Na década de 1930 - mais precisamente em 1932 -, com o surgimento de outras emissoras de rádio no Rio de Janeiro e nas principais cidades brasileiras, se iniciou o processo de consolidação de um novo modelo de exploração do serviço, com as emissoras recebendo autorização para veicular publicidade em até $10 \%$ de sua programação ${ }^{26}$. Nascia, assim, o modelo comercial que se mantém hegemônico na radiodifusão nacional até os dias atuais.

Nas duas décadas seguintes, o rádio se popularizou, e a competição pela audiência - o “produto" vendido pelas emissoras aos anunciantes - deu início a um acelerado processo de desenvolvimento técnico e artístico.

Já a televisão, no Brasil, começou a nascer em 1950, quando, em estúdios precariamente instalados em São Paulo, Assis Chateaubriand levou ao ar a TV Tupi Difusora. Ao contrário da televisão norte-americana, que se apoiou na indústria do cinema, a TV brasileira se submeteu à influência direta do rádio, utilizando inicialmente sua infraestrutura, seus técnicos e artistas e, conseqüentemente, um formato semelhante de programação (Mattos, 2000).

No início dos anos 1960, apenas 15 emissoras de TV operavam nas mais importantes

\footnotetext{
${ }^{26}$ Decreto 21.111 de 1 de março de 1932.
} 
cidades do país. Foi somente quando o consumo de produtos industrializados cresceu e, de alguma forma, se massificou, que as emissoras de televisão se tornaram economicamente viáveis e começaram a competir pelo faturamento publicitário, passando a exercer, simultaneamente, forte influência sobre os hábitos de consumo da sociedade brasileira (Ibidem).

O mesmo "esforço desenvolvimentista” levado à cabo pelos militares viabilizou a formação de redes nacionais de televisão, Organizações Globo $^{27}$ à frente. Para a formação de sua rede nacional, a Globo contou com apoio privilegiado da Embratel, que abriu linhas de crédito para a compra de televisores e filiou-se ao consórcio de satélites Intelsat, permitindo a transmissão direta de televisão, inicialmente para São Paulo e Rio de Janeiro e, depois, para os demais estados. Isso possibilitou, em 1969, a estréia do Jornal Nacional, principal telejornal do país nos últimos 35 anos.

O esforço pela criação de uma rede nacional de televisão alinhada às aspirações do governo fez com que o número de residências com aparelhos de TV saltasse de menos de 500 mil em 1960 para quase 30 milhões nos primeiros anos da década de 1980 (Abinee, 1995). Crescimento acelerado também foi registrado nos índices de cobertura da TV: em 1986 os sinais da Rede Globo já chegavam a 99,2\% da população (Ramos, 2006).

No mesmo período, surgiram outras emissoras comerciais no eixo Rio-São Paulo, o que resultou na concentração geográfica da produção audiovisual, restringindo fortemente o surgimento de pólos produtores e difusores de conteúdo regional.

\section{É também desta fase a influência norte-americana na radiodifusão brasileira,} simbolizada pela veiculação no rádio, e depois, na televisão, do Repórter Esso. Patrocinado pela empresa do ramo petrolífero Esso, e produzido pela agência de publicidade McCannErickson, o programa foi ao ar diária e regularmente em quinze países do continente latino-

\footnotetext{
${ }^{27}$ A Globo surgiu em 1965, tendo, inicialmente, o respaldo financeiro e técnico do grupo americano Time/Life. O envolvimento norte-americano da TV Globo foi, subseqüentemente, eliminado, embora isto só viesse a acontecer depois de ela ter usufruído das vantagens dos dólares e da experiência gerencial estrangeira (Herz, 1987).
} 
americano, incluindo o Brasil, entre a década de 1930 e o início da década de 1970. O Repórter Esso foi uma das mais eficazes armas utilizadas pelo imperialismo estadunidense nas Américas, estratégia ainda composta pela criação, pela Indústria Cultural daquele país, de personagens como o papagaio Zé Carioca e o incentivo à carreira de Carmen Miranda. Os resquícios dessa investida mantêm-se presentes de forma vigorosa nas linhas editoriais antinacionalistas das principais empresas de mídia nacional (Leal Filho, 2008).

No plano institucional, a partir da centralização pelo Ministério das Comunicações dos poderes de regulação, concessão e fiscalização dos serviços de radiodifusão, outras particularidades do setor foram radicalizadas, como a crescente promiscuidade nas relações políticas entre emissoras, governo federal e Congresso Nacional, e a ausência de controle público e social sobre a exploração as concessionárias e permissionárias do serviço (Rodrigues, 2008).

Com a Constituição Federal de 1988, foram determinados novos princípios para a exploração da radiodifusão. Mas, embora tenham sido estabelecidos, tais princípios seguem ignorados: passados 20 anos da promulgação da Carta Magna, muitos sequer foram regulamentados, por força do lobby das principais emissoras comerciais de televisão, que, como se evidenciará adiante, se apóia, no plano discursivo, no princípio jurídico da liberdade de expressão.

\subsection{1 - As garras do coronelismo eletrônico}

Exemplos de não aplicação das diretrizes determinados para a exploração do setor não faltam. Abusos são freqüentes, e a apropriação dos meios de produção e distribuição de informação por grupos financeiros e oligárquicos, no Brasil, é regra, não exceção. Como é notório, mesmo sendo este um conceito de difícil definição, não há qualquer indício de cumprimento da determinação constitucional de que a radiodifusão seja explorada de forma complementar pelos sistemas público, privado, estatal (art. 223) - salta aos olhos a hegemonia das emissoras de caráter privado-comercial. Tampouco há mecanismos que impeçam, como também reza a Constituição Federal vigente, a formação de monopólios ou 
oligopólios no setor (art. 220), o que, de fato, existe: cinco redes privadas controlam, mediante mais de uma centena de grupos afiliados, 599 emissoras de rádio e televisão em todo o território nacional, além de jornais, provedores de acesso, revistas, com conhecidos monopólios cruzados locais (FNDC, 2001). A concentração é ainda maior: uma única emissora detém 50\% da audiência e 70\% do faturamento publicitário da televisão brasileira (Mattos, 2002).

Sem qualquer órgão que efetivamente se dedique à fiscalização do setor (tarefa que deveria ser desempenhada pelo Ministério das Comunicações), são evidentes as violações aos princípios constitucionais que se referem ao conteúdo veiculado pelas emissoras de radiodifusão. O descontrole se verifica especialmente no momento de renovação das outorgas. O volume de processos e a falta de acompanhamento durante a vigência da concessão fazem com que não haja qualquer análise das obrigações previstas na legislação. A decisão é sempre pela renovação.

Além de um tempo demasiadamente longo para a finalização destes processos - fazendo com que as concessões permaneçam em funcionamento por anos sem a necessária aprovação do Congresso ${ }^{28}$-, tanto o Parlamento quanto o governo verificam somente as certidões fiscais negativas dos concessionários. Não há mecanismos para avaliar, por exemplo, se as empresas cumpriram a determinação constitucional (art. 221) de dar preferência às finalidades educativas, artísticas, culturais e informativas, assim como promover a cultura regional. O mesmo acontece com outras obrigações e responsabilidades

\footnotetext{
${ }^{28}$ A outorga de concessões e permissões (assim como as autorizações para as rádios comunitárias) só tem valor legal após o referendo do Congresso Nacional, como determina o artigo 223 da Constituição Federal. No caso da renovação das outorgas, contudo, a figura da licença precária existe e é largamente utilizada para manter no ar emissoras sem a necessária aprovação do Executivo ou do Congresso Nacional. Apesar de o texto constitucional ser explícito em relação à exigência desta dupla aprovação, emissoras e parcela da burocracia estatal apóiam-se no CBT e no Decreto 88.066/83 para justificar a renovação automática. Estes dois dispositivos combinados permitem que emissoras comerciais permaneçam no ar anos a fio, sem a análise de seus processos de renovação. Pesquisa realizada em 2007 pelo Observatório do Direito à Comunicação no Sistema de Controle de Radiodifusão da Anatel revela, por exemplo, que das 12 outorgas para transmissão em FM no município de Porto Alegre, apenas uma não está vencida. Em outras capitais, a situação se repete: em Belém, das 12 outorgas, apenas três estão em dia; no Rio de Janeiro, são 15 outorgas e apenas quatro não estão vencidas; em Recife, só uma em onze apresenta situação regular; em São Paulo, das 39 emissoras FM, 36 estão com as outorgas vencidas. Em vários casos, a licença para a transmissão está vencida duas vezes. A concessão para rádios dura 10 anos, mas há prazos vencidos há 12, 13 e até 17 anos. Uma rádio cuja outorga venceu em 1991 - como em dois casos registrados em Belém - deveria ter tido a autorização renovada naquele ano, depois em 2001 e, agora, logo mais, em 2011.
} 
legais como o respeito aos direitos humanos, previsto na garantia constitucional de respeito aos valores éticos (art. 221, IV). Estas e outras premissas para a exploração do serviço são “checadas" a partir de uma declaração unilateral do outorgado, que afirma, por carta, ter cumprido tais princípios (Intervozes, 2007).

Considerando, ainda, que apenas uma decisão judicial pode cancelar uma concessão de radiodifusão antes de vencido o prazo de sua vigência - determinação diversa da adotada na totalidade dos outros serviços púbicos objeto de concessão, que podem ter a outorga cassada por ordem do Executivo Federal depois de atestado o não cumprimento do contrato previamente estabelecido - tem-se que as concessões de radiodifusão, no Brasil, se tornaram praticamente capitanias hereditárias.

\section{Outro grande símbolo da radiodifusão nacional é seu vínculo estreito com o universo} político-partidário. A distribuição de concessões de radiodifusão a políticos, no Brasil, não é um fenômeno novo. Desde a década de 1950 esse tipo de prática se consolida no país. A situação se tornou crônica durante o governo Sarney (1985-1989), quando o então ministro das Comunicações, Antônio Carlos Magalhães, concedeu 82 concessões de TV, sendo 43 delas distribuídas no ano da votação da emenda constitucional que permitiu ao presidente estender seu mandato ${ }^{29}$.

Desde então, apesar de a Constituição Federal (arts. 54 e 55) determinar que deputados e senadores não podem, no exercício de seus cargos, controlar quaisquer concessões públicas, são notórios os casos em que parlamentares ou seus familiares são donos ou mesmo sócios das empresas que detêm concessões de rádio e $\mathrm{TV}^{30}$. No início da atual legislatura, 53 deputados federais e 27 senadores declararam possuir algum tipo de controle sobre veículos de comunicação, o que representa $10 \%$ da Câmara dos Deputados e 33,3\% do Senado

\footnotetext{
${ }^{29}$ O próprio ministro e o presidente presentearam a si mesmos com sete e três concessões de geradoras de televisão, respectivamente. No total, em três anos e meio, foram distribuídas 1.028 outorgas, sendo $25 \%$ delas em setembro de 1988, mês que antecedeu a promulgação da Constituição (Intervozes, 2007).

${ }^{30}$ Tal intimidade entre as elites políticas e as comunicações pode ser encontrada na Bahia, com a família Magalhães; no Maranhão, com a família do ex-presidente e senador José Sarney (PMDB), conhecida pelo controle do grupo Mirante ( $90 \%$ de todo o aparato de comunicação do Estado); e no Ceará, cujo senador representante, Tasso Jereissati (PSDB), tem vínculo com uma operadora de MMDS (TV paga via satélite), três operadoras de televisão a cabo, uma geradora de televisão, afiliada ao SBT, 31 retransmissoras e três rádios FM (Intervozes, 2007).
} 
Federal $^{31}$. Na Comissão de Ciência e Tecnologia, Comunicação e Informática (CCTCI) da Câmara dos Deputados - órgão que aprova a outorga e renovação das concessões -, pelo menos 16 têm envolvimento direto com emissoras de rádio ou TV, sendo que pelo menos dez deles já votaram em seus próprios processos de renovação de concessão ${ }^{32}$.

Estes são somente alguns dos exemplos que evidenciam a opção regulatória do Poder Concedente sobre a radiodifusão. Outros poderiam ser apresentados, como o relativo à precariedade do controle sobre a transferência de concessões entre particulares, a violação aos poucos limites de propriedade estabelecidos pela legislação, a deturpação na exploração de outorgas de caráter educativo ou a vergonhosa repressão a comunicadores comunitários (Rodrigues, 2009). Para efeitos da presente dissertação, no entanto, se pretende somente apontar o ambiente geral do setor, para o qual se acredita que os exemplos citados se encarregam de ilustrar.

\section{5 - Convergência e concentração}

Como visto, a face mais evidente da reforma setorial implementada na última década do século XX foi a privatização do Sistema Telebrás, período que coincidiu com a expansão inicial da TV por assinatura e da telefonia móvel. A mudança estrutural mais importante no cenário das comunicações, entretanto, foi introduzida pelo surgimento e desenvolvimento da Internet e pela digitalização dos conteúdos de áudio, vídeo e texto. Em poucos anos, o acesso à Internet se tornou importante ferramenta de informação, trabalho, estudo e lazer de milhões de pessoass em todo o mundo. No Brasil não foi diferente, apesar de o acesso à rede mundial de computadores ainda permanecer em patamares substancialmente baixos.

A Internet surgiu em plena de Guerra Fria, quando os norte-americanos, temendo possíveis ataques soviéticos aos seus meios de comunicação convencionais, desenvolveram a

\footnotetext{
${ }^{31}$ Pesquisa realizada pela Agência Repórter Social, acessível em http://www.reportersocial.com.br/noticias.asp?id=1278\&ed=Comunicação

${ }^{32}$ Estes números, porém, correspondem apenas aos políticos que possuem vínculo direto e oficial com os veículos de comunicação. Não estão contabilizadas, portanto, as relações informais e indiretas (por meio de parentes e laranjas), que caracterizam boa parte das ligações entre os políticos e os meios de comunicação no País (Intervozes, 2007).
} 
Arpanet - Advanced Research Projects Agency Network, uma rede de comunicação descentralizada. Assim, caso algum dos pontos de conexão da rede fosse destruído, a comunicação entre os órgãos e unidades de defesa do país não seria interrompida.

Na década de 1970, universidades e outras instituições de pesquisa obtiveram permissão para se conectar à Arpanet. Em alguns anos, a rede cresceu exponencialmente, tornando seu protocolo original de comutação de pacotes - chamado Network Control Protocol (NCP) inadequado, impulsionando a adoção do TCP/IP (Transfer Control Protocol/Internet Protocol). Em 1995, mais de seis milhões de computadores já estavam permanentemente conectados à Internet, além dos muitos terminais que ficavam on line apenas ocasionalmente ${ }^{33}$.

No Brasil, os primeiros passos da Internet foram dados pela comunidade acadêmica, cujos esforços resultaram, no final da década de 80 , em um projeto de pesquisa subordinada ao Ministério de Ciência e Tecnologia chamado Rede Nacional de Pesquisa (RNP). A missão do projeto era construir uma rede que interconectasse todas as universidades e centros de pesquisa brasileiros, especialmente aqueles com atividades relacionadas a redes de comunicação e computação. Como resultado da iniciativa, a RNP instalou o primeiro backbone $^{34}$ IP brasileiro ligando o Rio a São Paulo, utilizado para prover serviços de correio eletrônico na Conferência das Nações Unidas para o Meio Ambiente e o Desenvolvimento (mais conhecida como ECO-92), realizada em 1992 no Rio de Janeiro.

Ou seja, assim como nas telecomunicações e na radiodifusão em boa parte do mundo, a Internet se desenvolveu inicialmente como um serviço não-comercial. Primeiro, no plano militar. Depois, e mais importante - pois foi quando começou de fato a se expandir mundialmente - no plano acadêmico.

\footnotetext{
${ }^{33}$ Network Wizard Internet Domain Survey: <http://www.nw.com>

${ }^{34} \mathrm{O}$ backbone é o tronco principal do sistema de transmissão de dados. Os backhauls são a infra-estrutura que liga o backbone às redes de última milha. De forma alegórica, pode-se dizer que se as telecomunicações fossem uma árvore, o backbone seria o tronco, o backhaul, os galhos e a rede de última milha, a nervura que percorre cada folha.
} 
Mais tarde, na década de 1990, ao mesmo tempo em que se privatizaram as operadoras nacionais de telecomunicações, se radicalizou o processo de Convergência Tecnológica e as redes de telecomunicações, que antes serviam prioritariamente para a comunicação ponto a ponto (como o telégrafo e, depois, o telefone), passaram a participar no processo de produção simbólica das sociedades.

Este fenômeno - chamado também Convergência Digital - corresponde a uma mudança na relação tradicional entre redes e serviços, com o fim progressivo de redes segregadas para voz (cujo terminal é o telefone), dados (o terminal é o computador) e imagem (o terminal é o televisor): uma única rede pode transportar, armazenar e redistribuir todas as mídias. Mais do que isso, pode fazer isso não só por uma mesma rede, mas a partir de um único suporte tecnológico, a Internet (Rodrigues, 2008).

Embora ainda não completamente consolidado, o processo de convergência iniciado há alguns anos aponta como tendências gerais (1) a 'convergência setorial ou genérica', com a fusão entre os setores de telecomunicações, informática (TI), audiovisual (TV por assinatura) e radiodifusão (TV aberta); (2) a convergência entre serviços, com as mesmas aplicações e conteúdos sendo oferecidos por diferentes redes (telefonia fixa, banda larga e TV por assinatura oferecidos como um serviço único - chamado de tripleplay - ou, ainda, todos esses mais a telefonia celular - conhecido como quadruplay); (3) a convergência entre redes, com uma mesma rede oferecendo diferentes serviços; (4) a convergência entre terminais, com o mesmo terminal (fixo ou móvel) suportando diversos serviços (OECD, 2006).

Como conseqüência desse processo, serviços que possuíam dinâmicas próprias, mercados relevantes distintos, empresas líderes específicas em cada uma dessas atividades e, finalmente, diferentes graus de regulação e intervenção estatal, passam a se integrar através de um número crescente de serviços e de produtos, que convergem para uma estrutura de negócios similar. 
Nas indústrias de telecomunicações e conteúdo, a convergência acelerou o processo de oligopolização. À medida que a informação se digitaliza, tornando indistinto o transporte entre os vários meios de comunicação, a tendência é a de formação de grandes grupos econômicos transnacionais ${ }^{35}$. Abaixo dessas corporações, ainda resta uma série de empresas de alcance continental que operam em aliança com as gigantes transnacionais $^{36}$. E, como manifestação do fenômeno conhecido como financeirização do capital, estão os agentes financeiros ${ }^{37}$.

No plano nacional, além da importação em grande escala de conteúdo da indústria cultural norte-americana, mantém-se a tendência de monopolização do mercado de conteúdo audiovisual e jornalístico iniciada na década de 1970. Nos último 15 anos, este cenário se radicalizou, com o maior grupo produtor de conteúdo brasileiro passando a monopolizar o mercado de TV por assinatura ${ }^{38}$ e de cinema ${ }^{39}$.

\footnotetext{
${ }^{35}$ Como são os grupos Time-Warner (Warner, Time, Life, People, America on Line, HBO, Cartoon Network, CNN, TNT, DC Comics, Hannah Barbera), News (Fox, Sky), Viacom (Paramount, CBS, MTV,Nickelodeon, DreamWorks), Disney (ABC, Buena Vista, Disney, ESPN, Pixar, Miramax), Sony (Columbia, TriStar, MGM, Screem Gems, Sony-BMG), Bertelsmann (BMG, RTL, Sony-BMG), Universal (NBC, Universal, USA). No interior destes grupos estão todos os grandes estúdios de Hollywood, os principais canais de televisão (aberta e paga), gravadoras e editoras (Gindre, 2007, p. 138).

${ }^{36}$ São grupos como Liberty Media, Globo, Cisneros, Televisa, Canal+, Pearson, Mediaset, entre outros. Cabe registrar que esses conglomerados de mídia também possuem relações acionárias com o restante do universo corporativo. Assim, o mesmo grupo Sony é também uma das maiores empresas do setor eletrônico, produzindo TVs, DVDs, MP3 players, computadores e demais devices em que serão exIbidemos os conteúdos produzidos justamente pela sua divisão de mídia. Ou, por exemplo, a General Eletric (GE), acionista majoritária do grupo Universal (Gindre, 2007, p. 139).

${ }^{37}$ No conselho do grupo Time-Warner, por exemplo, estão representantes do Citi Group, do Morgan Stanley e do AmEx. Já na direção do grupo Viacom há membros do J. P. Morgan Chase (a mesma instituição financeira que também possui assento na direção da Verizon) (Gindre, 2007, p. 139).

${ }^{38}$ No Brasil, a Globopar, empresa holding das Organizações Globo, possui participação acionária (apesar de minoritária), nas duas principais operadoras de TV por assinatura do país, NET Serviços e Sky. Estas mesmas operadoras, além de outras menores (como a TV Cidade, presente em Niterói, São Gonçalo, Volta Redonda, Aracaju e Juiz de Fora, entre outras), mantêm contratos de exclusividade com a NET Brasil (não confundir com NET Serviços), empresa $100 \%$ controlada pelas Organizações Globo, que fornece o conjunto dos conteúdos para as operadoras, entre eles os canais da Globosat, como a GloboNews, GNT, MultiShow, SportTV 1 e 2, USA, Telecines (5), Canal Brasil e Premiere Futebol Clube. Com a aprovação da aquisição da Vivax pela NET Serviços, a marca NET Brasil passou a dominar 81,49\% do mercado de TV paga do país. Isso significa que, de cada cem assinantes de TV por assinatura, 81 vêem programação gerenciada pela NET Brasil. Este nível de controle do mercado permite ao grupo Globo difundir os canais da Globosat e, inversamente, criar dificuldades para os produtos de seus potenciais concorrentes, como os canais produzidos por Grupo Abril, Bandeirantes, Record e programadoras de pequeno porte, que deixam de fazer parte das opções de escolha dos assinantes (Rodrigues, 2008).

${ }^{39}$ Entre as dez maiores bilheterias da retomada do cinema brasileiro, nove são filmes co-produzidos pela Globo Filmes (ANCINE, 2008).
} 


\section{O setor de telecomunicações do país também é símbolo desse mesmo processo, com} forte tendência de concentração do mercado em apenas três grupos econômicos (dois estrangeiros, Telefônica e Telmex; e um nacional, a Oi) com atuação nas telefonias fixa e móvel, na TV por assinatura e na oferta de acesso à Internet ${ }^{40}$. Além dos serviços oferecidos diretamente ao consumidor, tais grupos são detentores de backbones (troncos) que percorrem o território nacional, de cabos submarinos que ligam o Brasil à América Latina, aos EUA e à Europa, e, no caso específico da Telmex, também de satélites que cobrem o território nacional. Os dois grupos estrangeiros são eles próprios detentores de redes em praticamente todo o território das Américas (Rodrigues, 2008).

Pode-se justificar esta tendência pelo fato do mercado de telecomunicações apresentar como principal característica econômica a grande necessidade de capital para viabilizar sua operação. Construir redes de telecomunicações, especialmente as terrestres, por fio (qualquer que seja ele), exige investimentos de grande porte, as conformando como essencial facilities $^{41}$. Tal fato, combinado com o elevado grau de progresso tecnológico e a obrigatoriedade de instrumentos de Estado - como outorgas - de transferência de exploração de serviços de interesse coletivo, induz a elevadas barreiras à entrada neste mercado, que se apresenta na maioria dos países como oligopolista, quando não duopolista ou mesmo monopolista, sobretudo na modalidade do serviço local (Rodrigues, 2008).

Nesse contexto, a concentração setorial se torna o caminho para a expansão da acumulação capitalista: ganhos de escala das empresas passam a ser decorrentes, em geral, da

\footnotetext{
${ }^{40}$ O grupo espanhol Telefónica ingressou no Brasil em 1998 a partir da incorporação da então Telesp (Telesp - Telecomunicações de São Paulo S.A.). Atualmente, o grupo oferta telefonia fixa, telefonia móvel, banda larga, televisão por assinatura. O grupo nacional Oi (Telemar), também ingressou no mercado em 1998 a partir da incorporação das empresas originárias do Sistema Telebrás na Região I. A empresa oferta serviços de telefonia fixa, telefonia móvel, banda larga e televisão por assinatura. O mesmo grupo incorporou a Brasil Telecom, outra empresa brasileira que atua nas áreas de telefonia fixa, telefonia móvel e Internet banda larga. Já o grupo mexicano Telmex ingressou no Brasil em 2004 a partir da aquisição da Embratel. A Telmex controla, desde 2005, a NET Serviços (que tem as Organizações Globo como sócia), a Embratel, além da operadora de telefonia movel Claro. A exceção pontual a este cenário de concentração em três grupos, além da espelho GVT, refere-se à operadora de DTH Sky, que possui fatia importante (31\%) do mercado de TV por assinatura e cuja propriedade atual é da Liberty Media, também em aliança com as Organizações Globo, que possuem $26 \%$ da operadora (Rodrigues, 2008).

41 "Infraestrutura essencial”, ou "essential facility” é termo utilizado para infraestruturas que consistem bens ou serviços que permitem acesso a um grupo de usuários ou consumidores, mas cujo custo é elevado a ponto de inviabilizar sua duplicação. Trata-se, portanto, de um monopólio natural que deve estar sujeito a regulação (Salomão Filho, 2002).
} 
consolidação de operações entre diferentes empresas prestadoras, via fusões, aquisições, joint ventures, etc. (CADE, 2008). 


\section{7 - ESFERA PÚBLICA E COMUNICAÇÃO}

A teoria da esfera pública delineada na obra de Jürgen Habermas é de grande repercussão, orientando, de forma indireta, a elaboração de diversos marcos regulatórios nacionais no campo da comunicação. O autor alemão provocou, e ainda provoca, reações impetuosas no conjunto das Ciências Humanas, tanto dos que reafirmam suas idéias quanto de seus críticos. Nos estudos do fenômeno da comunicação, em especial nos que se aproximam da Sociologia ou da Filosofia, é raro encontrar pesquisas que não abordem sua obra, que procurou desenvolver o conceito originário da Ágora grega de espaço público e esfera pública $^{42}$, aplicando-o aos diferentes tempos históricos.

No conceito idealizado por Habermas, a esfera pública emerge a partir do surgimento dos primeiros panfletos, brochuras e jornais impressos entre os séculos XVI e XVIII, e deve ser compreendida como o âmbito da vida social em que se realiza - em várias arenas, por instrumentos diversos e em torno de variados objetos de interesse específico - a discussão permanente entre pessoas privadas reunidas num público (Gomes, W., 1998a). Nesta esfera pública - idealizada, evidentemente - é a argumentação racional a única motriz dos processos de formação de opinião, sendo ela livre das influências dos poderes político e econômico. “A esfera pública pode ser descrita como uma rede adequada para a comunicação de conteúdos, tomadas de posição e opiniões; nela os fluxos comunicacionais são filtrados e sintetizados, a ponto de se condensarem em opiniões públicas enfeixadas em temas específicos” (Habermas, 1984, p. 92, grifos do autor).

Esta esfera pertence ao "mundo da vida", que difere dos sistemas econômico e estatal, sendo composta pela sociedade civil e por elementos diversos, inclusive por organismos de mediação entre Estado e mercado. Neste mundo da vida, afloram reivindicações de novos direitos e novas formas de comportamento diante das instituições de poder. "Do mesmo modo que o mundo da vida tomado globalmente, a esfera pública se reproduz através do

\footnotetext{
${ }^{42}$ As leituras realizadas não permitiram definição segura que separa estes dois termos - "esfera pública” e "espaço público" - em compartimentos estanques, e parecem, inclusive na obra de Habermas, serem palavras que apontam um mesmo conteúdo conceitual. Nesta dissertação, é feito o uso prioritário do termo "esfera pública”, por sua conotação de espaço “imaterial”, “intangível”, apropriada para a reflexão proposta.
} 
agir comunicativo, implicando apenas no domínio da linguagem natural; ela está em sintonia com a compreensibilidade geral da prática comunicativa cotidiana" (Ibidem, p. 92).

Nesta esfera idealizada, livre de interferências outras que não a argumentação, impõe-se uma paridade inicial entre os indivíduos: desprovidos de poder político e econômico que eventualmente possuem fora dela, há uma situação de igualdade, que se modifica pelo próprio processo discursivo, e apenas por ele. Nesta perspectiva ideal, a esfera pública “tanto é o âmbito em que um público busca no raciocínio de pessoas privadas esclarecimentos e entendimentos recíprocos, quanto é a arena de concorrência pública das posições privadas apresentadas em forma de argumento” (Gomes, W., 1998a).

À luz da incontestável presença dos meios de comunicação nas sociedades contemporâneas, é lógico deduzir haver um espaço próprio dos meios de comunicação - como uma esfera pública “mediática” -, composta pelo conjunto de veículos e formas de comunicação mediadas pelas tecnologias e suportes, em sua multiplicidade: dos grandes aos pequenos, dos privados aos públicos, dos impressos aos audiovisuais, dos analógicos aos digitais. Esta esfera é imaterial, intangível, de limites e contornos indefiníveis, mas é a esfera por onde trafegam os fluxos de informação das mais variadas ordens - como as produções culturais, apesar de Habermas ter como foco as informações noticiosas e as opiniões políticas -, cuja importância para as diferentes dimensões da vida humana é irrefutável.

Como sintetizou Eugênio Bucci: “o espaço público é ele mesmo um campo gerado pela comunicação social” (Bucci, 2004).

E o próprio Habermas: a esfera pública é uma "rede para a comunicação de informações e pontos de vista”. Ou, em outras palavras, “como uma estrutura comunicacional [...] não se refere nem às funções nem ao conteúdo da comunicação de todo dia, mas ao espaço social gerado pela comunicação” (Habermas, 1988). 


\section{1 - Imaginário e esfera pública}

Por meio das relações mantidas na esfera pública se constrói o imaginário social, moldando o universo de representações simbólicas que caracterizam os valores e crenças de uma determinada sociedade. Composto por um conjunto de relações imagéticas que atuam como memória efetiva de uma cultura, se constitui como um "substrato ideológico mantido pela comunidade”, uma produção coletiva, “depositária da memória dos indivíduos e dos grupos (enquanto elementos sociais que compartilham modos de ser, pensar e agir) que recolheram de seus contatos com o cotidiano bem como as percepções de si mesmo e dos outros” (Moraes, 2009, p. 29 e 30).

O imaginário social se traduz por ideologias, símbolos, alegorias, rituais e mitos, que determinam visões de mundo e modelam estilos de vida. Por meio dele, “uma coletividade designa a sua identidade; elabora uma certa representação de si; estabelece a distinção dos papéis e das posições sociais; exprime e impõe crenças comuns”, fixando, “uma representação global e totalizante da sociedade como uma 'ordem' em que cada elemento encontra o seu 'lugar', a sua identidade, a sua razão de ser”. É por meio do imaginário que se podem atingir as aspirações, os medos e as esperanças de um povo. Nele, "as sociedades esboçam identidades e objetivos, detectam inimigos e organizam o passado, presente e futuro" (Ibidem, p. 31).

Imaginário social e esfera pública, assim, se entrelaçam em um todo indivisível, tendo os meios de comunicação seu eixo articulador. Afinal, como bem afirmou Karl Marx, os meios de comunicação "transportam signos; garantem a circulação veloz das informações; movem as idéias; viajam pelos cenários onde as práticas sociais se fazem; recolhem, produzem e distribuem conhecimento e ideologia” (Marx, 1997, vol. 1 - p. 67).

Em síntese, a contribuição do conceito de imaginário impõe à esfera pública, de forma inequívoca, além da circulação de informação jornalística (ou informação de opinião) - apesar dessa ter sido o motor de seu surgimento - o fluxo de conteúdos culturais e simbólicos cada vez mais vigoroso, especialmente a partir do século XX. Se a esfera 
pública nasceu “jornalística”, “informativa” ou “de opinião” como afirmou Habermas, o desenvolvimento acelerado da Indústria Cultural moldou-a sem que estas divisórias possam ser erguidas de modo claro e estanque, compondo um todo único e indivisível. 


\section{8 - A PRIVATIZAÇÃO DA ESFERA PÚBLICA}

O próprio Habermas identifica a “decadência” desta esfera pública inicial, que teria perdido sua autenticidade, a partir da metade do século XIX: a imprensa de opinião, instituição essencial do modelo autêntico burguês, é substituída progressivamente pela imprensa comercial, agora ela mesma um mecanismo de reprodução do capital, induzindo ao que o autor denomina “refeudalização do espaço público”, agora “encenado”, “fictício”, dominado pela comunicação e pela cultura de massas. De veículo de opinião, a imprensa se torna produção de opinião, sendo o trabalho iluminista coletivo substituído por uma nova classe, os profissionais de mediação. A “opinião”, dessa forma, já não mais era formada pelo conjunto da sociedade em uma discussão pública e racional, mas imposta pelos meios de comunicação de massa (Habermas, 1984).

No início do século XX, essa situação se radicalizou com o desenvolvimento da Indústria Cultural. As novas técnicas se ampliaram sob o mantra das corporações líderes da expansão capitalista, tornando-se simultaneamente um motor ideológico do sistema e uma atividade econômica com forte potencial para a acumulação financeira.

O desenvolvimento da televisão é chave nesse processo, cumprindo a função primordial de veículo de publicidade para as empresas em ascensão e, simultaneamente, para a produção de gostos, valores e preferências materiais (Bolaño, 2000).

A diferença inicial entre os modelos de exploração da radiodifusão dos EUA (comercial) e da Europa e Japão (serviço público) é elucidativa. Do ponto de vista do capital, a solução européia só é aceitável como "solução provisória, num momento em que importantes fatores de ordem política põem como prioritários a manutenção do equilíbrio social e o esforço da reconstrução nacional pós-guerra, fato semelhante ao que já havia ocorrido anteriormente com o rádio” (Ibidem, p.21).

A perpetuação desse tipo de organização, no entanto, limita a ação do capital, impedindo, por um lado, o pleno desenvolvimento dos mecanismos de publicidade, cruciais para o 
próprio processo de acumulação em geral sob o capitalismo monopolista, e, por outro, fechando um campo de investimento crescentemente interessante para o grande capital em função da própria importância, no capitalismo avançado, desse mecanismo de mediação fundamental que é a televisão.

Assim, a discussão sobre a privatização é recorrente nos conjunto dos países europeus desde a década de 1940 e já em 1954 se estabelece o sistema misto na Inglaterra, ao mesmo tempo que, desde o início, a televisão privada de Luxemburgo representava uma ameaça constante à estabilidade dos sistemas estatais de seus países vizinhos. A partir dos anos 1970, com o avanço neoliberal, a questão se torna dramática, ensejando o início à reforma do setor audiovisual, que culminará com a constituição de importante setor de mercado nos mais importantes países europeus, revertendo a situação vigente no pós-guerra (Bolaño, 2000).

Fato é - e este já é lugar comum na Economia Política da Comunicação - que a informação assumiu a dianteira como fonte alimentadora de engrenagens indispensáveis à hegemonia do capital. O controle da informação, estocada, processada, em andamento ou atualização, se situa no vértice das atuais estruturas de dominação (Dantas, 2002, Gindre, 2007).

Em âmbito internacional, o maior exemplo dessa inflexão é o chamado Acordo Trips, tratado internacional integrante do conjunto de acordos assinados em 1994 que criou a Organização Mundial do Comércio (OMC). Também conhecido como Acordo Relativo aos Aspectos do Direito da Propriedade Intelectual Relacionados com o Comércio (ADPIC), o Trips passou a tratar os bens culturais no âmbito da OMC. A assinatura do Acordo pelo Brasil em 1998 determinou, na busca da proteção do valor comercial dos produtos gerados pela Industria Cultural, entre outras questões, a revisão da Lei de Direitos Autorais nacional.

A mesma lógica percorreu o desenvolvimento das telecomunicações. Até as décadas de 1980 e 1990, a maioria dos países do mundo possuía, neste setor, monopólios estatais, orientados a favorecer os interesses maiores de cada uma das nações. Privatizadas no bojo 
da reforma neoliberal, passaram a se orientar para atender interesses de seus proprietários e acionistas, geralmente situados nos países líderes do processo de expansão capitalista.

\section{1 - A marca da apropriação nativa}

Algumas das principais características sistêmicas das comunicações brasileiras foram anteriormente apresentadas (ver cap. 06), colocando em evidência a apropriação da comunicações nacionais por interesses privados. Uma destas características, por sua força e impacto político e cultural, merece ser objeto de passagem específica.

Como aponta Bucci (2004, p. 234), “o espaço público brasileiro se forjou a partir do alicerce dado pela centralidade exercida pela TV, o que é o mesmo que dizer: pela centralidade da Globo. Ela se tornou o fórum por excelência para a tematização dos assuntos que constituem com seu fluxo o próprio imaginário social”.

Nascida em 1965, a Rede Globo se tornou nas décadas de 80 e 90 uma presença "ubíqua, ininterrupta, totalizante na vida dos brasileiros”. A interferência exercida por ela e pelos seus donos, direta e indiretamente, em vários episódios da história política no país, conferelhe uma aura de "quarto poder", que as vezes ultrapassaria e subjulgaria os outros três.

Embora seja arriscado cair em simplificações totalizantes, é fato que, mesmo em tempos de convergência tecnológica, as Organizações Globo - na qual devem ser compreendidas também as suas ramificações regionais - ainda dispõe da prerrogativa de prestar-se não exatamente como um meio de comunicação, “mas como um lugar, um topus nuclear em que a sociedade brasileira elabora seus consensos e equaciona seus disssensos. A Globo é, por assim dizer, um palco do espaço público que ela mesma delimita. Ela soube forjar uma gramática universalizante através da combinação do melodrama (a novela) com o telejornal, num repertório dinâmico em que nacionalidade se reconhece e se reelabora” (Bucci, 2004, p. 224). 
A Rede Globo, assim, une e iguala, no plano do imaginário, um país cuja realidade é constituída de contrastes, conflitos e contradições violentas. A empresa conseguiu "produzir a unidade imaginária onde só havia disparidades materiais. Sem tal unidade, o Brasil não se reconheceria Brasil. Ou, pelo menos, não se reconheceria como o Brasil que tem sido”. Mas como um país com tamanha pobreza e com tamanha carência de liberdades democráticas pôde produzir uma televisão tão rica e bem equipada? A resposta reside no fato da televisão brasileira ser ultramoderna exatamente porque a realidade que lhe serviu de canteiro era vitimada pelo atraso, tanto no campo das liberdades como no campo da distribuição de riqueza. Como bem afirmou Bucci (2004, p. 221-224), no Brasil “a televisão compensou, com seu avanço extraordinário, a falta de modernidade da vida social e política”.

\section{2 - As comunicações a serviço do capital}

Os resultados práticos dessa apropriação dos meios de comunicação, por parte do grande capital financeiro transnacional ou por seus representantes nacionais, se manifesta na prevalência das lógicas comerciais na produção e nas formas de circulação da informação. De forma geral, como resume Moraes (2009, p. 17), esse atores buscam conformar um espaço público baseado num "reduzido mosaico interpretativo dos fenômenos sociais; na escassa variedade argumentativa, em razão de enfoques que reiteram temas e pontos de vista; na supremacia de gêneros sustentados por altos índices de audiências e patrocínios; na baixa influência pública nas linhas de programação; no desapreço aos movimentos sociais nas pautas e coberturas; na incontornável disparidade entre os enlatados adquiridos nos Estados Unidos e a produção cultural audiovisual nacional”.

Os meios de comunicação, assim, desempenham o papel de "servidores da hegemonia e guardiões da tradição”, ocupando posição proeminente no âmbito das relações sociais, fixando os contornos ideológicos da ordem hegemônica e elevando o mercado à instância máxima da representação de interesses. Não raro, o discurso dominante fabricado pelos aparatos midiáticos tenta neutralizar a circulação de visões dissonantes e contestadoras. Enfraquecendo ou silenciando pontos de resistência, esse discurso objetiva "modelar a 
impiedosa lógica corporativa da obtenção de lucros e o poder político em um estado de coisas normal [...] convertendo, no processo, a resistência racional em algo completa e praticamente irrealista, irracional, utópico, etc” (Ibidem, p. 18).

É, portanto, no domínio da comunicação que se esculpem os contornos ideológicos da ordem hegemônica e se procura reduzir ao mínimo o espaço de circulação de idéias alternativas e contestadoras - por mais que estas continuem se manifestando e resistindo. A meta é esvaziar análises críticas e expressões de dissenso, evitando atritos entre as interpretações dos fatos e seu entendimento por parte de indivíduos, grupos e classes.

Do ponto de vista das corporações midiáticas, trata-se de regular a opinião social através de critérios exclusivo de agendamento dos temas que merecem ênfase, incorporação, esvaziamento ou extinção. “O ponto nodal é disseminar conteúdo que ajudem a organizar e a unificar a opinião pública em torno de princípios e medidas em torno de princípios e medidas de valor. Quando intencionalmente se busca neutralizar ou silenciar representações, identidades e aspirações presentes em um contexto histórico-social, “almeja-se impedir que expressões singulares desordenem a memória que se quer oficializar ou contraditem as linhas do imaginário fixadas perante a comunidade” (Ibidem, p. 45).

Interferindo preponderantemente na cartografia do mundo coletivo, os meios de comunicação hegemônicos propõe um conjunto de linhas argumentativas sobre a realidade, aceitas ou consideradas por amplos setores da sociedade. Assume, pois, como aponta Chauí (1982, p. 21), uma função ideológica que consiste em compor um “imaginário e uma lógica de identificação social com função precisa de escamotear o conflito, dissimular a dominação e ocultar a presença do particular, enquanto particular, dando-lhe aparência do universal”.

Para utilizar os termos de Habermas, a tarefa da Indústria Cultural é, então, substituir eficazmente mecanismos internos de reprodução simbólica para poder colonizá-lo a favor do capital e do Estado, garantindo assim o trabalho de mediação para o qual existe. 
Antes que se faça tarde: essas considerações, evidentemente, não buscam conceber o campo midiático como um todo homogêneo, pois se trata de um campo permeado por contradições, oscilações de gostos, preferências e expectativas. Seria miopia enxergar apenas manipulações no que a mídia difunde, ou supor que toda a audiência submerge na passividade crônica. Bem sabemos que existem respostas, interações e assimilações diferenciadas por parte do público consumidor.

Enquanto mediadora autoassumida dos desejos, contudo, é certo que a mídia tenta identificar indicações do cotidiano e eventuais alternâncias de sentimentos que podem incidir em predisposições individuais de consumo. Ainda que prescrevam fórmulas e juízos, não há dúvida de que, em maior ou menor grau, absorvem, essencialmente por razões de mercado, determinadas inquietações do público.

\section{3 - Novas mídias, novos desníveis}

Nos últimos dez anos, multiplicaram-se exponencialmente as publicações e análises sobre os impactos da convergência tecnológica e, mais especificamente, sobre os efeitos da expansão do acesso e uso da Internet nos diferentes aspectos da vida humana, determinando um repensar teórico e conceitual, exposto, em certa medida, por autores como Pierre Lévy (2000) e Manuel Castells (2003), que debruçaram-se, respectivamente, sobre os fenômenos do "ciberespaço" e da nova "sociedade em rede”. De fato, a comunicação de massa do século XX se referia a produtos de informação e entretenimento padronizados e distribuídos a grandes públicos através de diferentes tecnologias unidirecionais. A nova mídia modifica estas condições: muitas vezes seus produtos não se originam de uma fonte central e, em função da própria essência das redes IP (Internet Protocol), estas mídias permitem, de um 
lado, um maior controle sobre as informações recebidas e, de outro, a possibilidade de tornar cada cidadão produtor de conteúdo ${ }^{43}$.

É inegável que a organização em rede, apesar de não ser fator emancipatório per si, certamente altera o paradigma da comunicação de massa do século $\mathrm{XX}$, por permitir a produção e difusão de informação descentralizada. As tecnologias facultam novas modalidades de entretenimento e informação, e até outras formas de intervenção política a desenvoltura dos movimentos antiglobalização capitalista na Internet não nos deixa ignorar a realidade.

Fernando Broncano (2000, p. 82-83) resume o escopo da tecnologia ao situá-la como “a capacidade de abrir possibilidades e criar oportunidades”. A ser ver, “a tecnologia é antes de tudo um espaço de alternativas possíveis: é o lugar desde o qual se pode configurar o futuro no que depende da ação humana”. Mas este entendimento, que destaca corretamente disversos usos e possibilidades, não autoriza desconsiderar os domínios monopólicos e a necessidade de distintas competências para lidar com as tecnologias.

Ainda nas décadas de 1980 e 1990, pesquisadores já alertavam para o perigo das tecnologias acabarem instituindo novas segregações, na medida em que pudessem se tornar o centro irradiador de informações pertinentes sobre diversas esferas da vida social. O atraso seria fatal a países periféricos, na medida em que estariam mais distantes de sistemas que instruíssem decisões estratégicas e ampliassem a base de conhecimentos. A brecha digital, como aponta Hopenhayh (2002), tende a aprofundar desigualdades não apenas nos acessos culturais, como também na produtividade e no desempenho de atividades que não podem prescindir de sistemas e ferramentas tecnológicas:

“Quem não está conectado estará excluído de maneira mais intensa e
variada. A brecha acirra os contrastes entre regiões, países e grupos sociais.
Países menos digitalizados vão sendo confinados ao quintal da globalização

${ }^{43}$ As estimativas da consultoria IDC são impressionantes: a quantidade atual de informação em meio digital mais de 161 bilhões de gigabits - seria suficinente para cobrir a Terra quatro vezes, equivalendo a três milhões de vezes a infortmação contida em todos os livros já escritos até hoje ou a 12 pilhas de livros que corresponderiam, cada uma delas, à distância entre a Terra e o Sol. 
em termos de intercâmbio cultural, protagonismo político, crescimento econômico e, em consequência disso tudo, bem-estar social” (Hopenhayh , 2002, p. 328).

Ao mesmo tempo em que amplia as nossas capacidades de conhecer, imaginar e interagir, o delírio tecnológico não desfaz desigualdades, e sim acentua desníveis, repõe tensões sociais e se deixa apropriar pela voracidade mercantil. Se por um lado há multiplicação da oferta de informação e diversão, de outro há um processo de centralização das fontes emissoras de conteúdos multimídias.

Esta nova dinâmica, ainda em consolidação, cria constrangimentos de diferentes ordens à produção e circulação de informação. Na camada física de transporte de dados, a propriedade dos fios e licenças de transmissão por ondas aéreas, necessárias à comunicação, oferece suporte para o controle pelos que detêm estes meios (radiodifusores e operadoras de telecomunicações, por exemplo). Na camada lógica - os padrões, protocolos e softwares necessários, como sistemas operacionais - também permitem o controle sobre o fluxo de informação e, portanto, sobre as oportunidades de produção de conteúdos. Por fim, na camada de conteúdo, a propriedade intelectual e os modelos de negócio que dependem de um controle rígido sobre a informação - insumo essencial para novas criações - oferecem aos seus proprietários a capacidade de controlar o uso e a circulação destas informações (Benkler, 2007; Lessig, 2005).

São diversas as consequencias práticas desse processo. De um lado, a criação de embaraços à produção e circulação de conteúdo pelos que possuem acesso às redes de telecomunicações, por meio de travas tecnológicas ou regras excessivas de controle da propriedade intelectual. De outro, e talvez mais grave, a exclusão de parcela significativa da população do acesso a estas novas formas de produção e difusão de informação, mazela consagrada pela expressão “exclusão digital”.

Lembre-se, ainda que de modo superficial, que a própria "administração técnica” dos nomes e domínios da Internet (absolutamente central na gestão da rede) é feita por uma organização privada vinculada ao Departamento de Comércio do governo norte-americano, 
a ICANN (sigla em inglês para Corporação da Internet para Atribuição de Nomes e Números), e, por isso, é passível de controle unilateral e privilegiado por parte daquele governo, o que, evidentemente, coloca em xeque o caráter livre da rede mundial de computadores (Afonso, 2002).

\section{4 - A consolidação das desigualdades}

A evolução técnica deveria ampliar o conhecimento das sociedades e dos homens. Mas, na prática, ocorre o inverso: as técnicas avançadas são apropriadas por elites e atores privilegiados em função de objetivos determinados. A explosão inovadora não representa um bem comum, nem uma conquista repartida pela maioria das sociedades. Grandes empresas e instituições hegemômicas detêm a prerrogativa de utilizá-la em função de suas ambições particulares. São elas que dispõem de poderia financeiro, influência política, capacidade industrial e esquemas de distribuição pelas continentes - tudo isso facilitado pelas desregulamentações e privatizações dos últimos 25 anos.

As tecnologias estão longe de equacionar desníveis nos acessos a informações e inovações. Ainda que os processos não sejam lineares e comportem variações, a digitalização não suprime e até pode repor divisórias entre conectados e desconectados. Diferenças e desigualdades se evidenciam quando analisamos as condições de acesso ou exclusão às redes, o que induz Nestor García Canclini (2004, p. 79) a concluir: "Ler o mundo com a chave das conexões não elimina as distâncias geradas pelas diferenças, nem as fraturas e feridas das desigualdades.

Constitui-se, então, como bem define Bolaño (2000), uma “assimetria comunicacional”, com uma parte ínfima da sociedade proprietária dos veículos, enquanto a coletividade é apenas destinatária. Assim, ao preservar o momento de igualdade de acesso geral à informação (o acesso ao sinal da TV aberta é, em tese, livre), os meios de comunicação de massa permitem que a desigualdade se exerça no nível do processo produtivo.

"[No capitalismo] transparece a desigualdade do sistema, mascarada pela igualdade forma aparente definida no nível da circulação mercantil. 
Também a comunicação deixa de ser uma comunicação entre iguais e se transforma em comunicação de classe” (Bolaño, 2000, p. 42).

Num certo sentido, tal constatação nada mais é do que uma conseqüência do desenvolvimento da troca de informações baseada na busca pela acumulação financeira permitida pela evolução das técnicas a partir dos tipos móveis de Gutemberg.

É possível deduzir, em síntese, que o desenvolvimento das comunicações impressas e eletrônicas, com a conseqüente formação de monopólios e oligopólios mundiais, nacionais e regionais (a depender do setor específico ao qual se refere: telecomunicações, radiodifusão aberta, TV por assinatura), passou a ser determinante aos processos de acumulação do capital e liderou de forma inequívoca a reprodução ideológica do capitalismo do século XX.

Ao mesmo tempo em que cumpria esta missão, a expansão do uso das telecomunicações, da radiodifusão e da mídia impressa permitiu a construção de privilégios no exercício e na fruição dos direitos e liberdades comunicativas, enquanto os diferentes povos, à exceção das elites aos quais estão submetidos, foram privados da fruição plena da liberdade de expressão na esfera pública. Com a evolução da técnica e a necessidade de altos recursos financeiros para erguer instituições de mídia ou ter acesso às redes de telecomunicações, a manifestação da liberdade de expressão passou a não mais depender de um ato de vontade de indivíduos ou grupos sociais. Como afirmou Habermas, o espaço próprio dos meios de comunicação, desprovido de sua autenticidade, acabou por determinar a "refeudalização" do espaço público ou, em outras palavras (talvez até melhores), a sua privatização.

Estas desigualdades no acesso aos meios e conhecimentos para produzir e veicular informações são a raiz da demanda político-jurídica pelo reconhecimento do direito à comunicação. 


\section{9 - A LIBERDADE COMO PRIVILÉGIO}

Não obstante o princípio jurídico da liberdade de expressão, como visto, por sua origem na filosofia liberal, possua sentido negativo, sua interpretação moveu-se de acordo os diferentes tempos e espaços históricos. Cada uma das sociedades imprimiu ao conceito um olhar distinto, acompanhando os anseios e aspirações dos diferentes povos.

Eric Barendt (1985), a partir do estudo dessas múltiplas leituras, aponta que as interpretações (ou teorias) da liberdade de expressão podem ser agrupadas genericamente em três grupos.

A primeira teoria, afirma o autor, se baseia na importância de uma discussão livre para se atingir a “verdade”. Essa teoria é comumente relacionada à John Stuart Mill, mas também pode ser atribuída, dois séculos antes, a John Milton. De acordo com Barendt, há um número relativamente grande de versões derivadas das idéias de Mill e Milton, mas a sua afirmação se dá, em geral, pela relativização da verdade, sendo a sua aproximação máxima somente possível pela concorrência das idéias no espaço público.

A segunda teoria vê a liberdade de expressão como um direito individual fundamental para o desenvolvimento da personalidade. Sob essa perspectiva, a liberdade de expressão é primariamente uma liberdade face ao Estado, sendo essa interpretação, por isso, muito mais simples de se consolidar juridicamente, por demandar exclusivamente a abstenção do Estado na esfera privada dos indivíduos.

A terceira teoria aponta ser a liberdade de expressão o motor da participação dos cidadãos na democracia. O propósito número um deste direito seria permitir que os cidadãos, em primeiro lugar, compreendam os processos e idéias políticas presentes em uma determinada sociedade, para, assim, terem condições de participar da construção da democracia. Isso significa reconhecer limites ao poder da maioria, "pois somente com a discussão sobre as formas de governo e idéias políticas é possível construir melhores leis e instituições” (Barendt, 1985, p. 21, tradução nossa). Sob essa perspectiva, para se atingir o propósito 
maior da liberdade de expressão, são necessárias regras que permitam maximizar a presença de diferentes idéias no espaço público. É essa perspectiva, afirma o autor, que determinar às democracias da Europa ocidental e outros países (como o Japão, o Canadá e, em certa medida, o próprio Estados Unidos) a regularem as comunicações de forma a elevar ao máximo a diversidade e a pluralidade na esfera pública.

O autor reconhece, contudo, o conflito permanente entre as diferentes teorias, que se chocam e se entrelaçam a partir das realidades práticas de cada uma das nações.

Fato é que desde o início do século XX, a necessidade de prestações estatais positivas para o exercício pleno da liberdade de expressão e a garantia de outros direitos fundamentais ligados ao campo da comunicação - por meio de determinações regulatórias e da promoção de políticas públicas - induziu diversos países a incidir na organização dos serviços de comunicação, mediante a intervenção estatal direta (como no caso dos europeus e dos japoneses) ou ao estabelecimento de limites à formação de monopólios (como nos caso dos EUA).

Estes processos sempre foram - e continuam sendo - permeados por fortes tensões políticas e jurídicas. Em geral, independentemente do grau de incidência dos Estados sobre o setor, as iniciativas de regulação dos meios de comunicação social que buscam restringir abusos e promover a diversidade são rechaçadas por um discurso “mundialmente comum”, sendo classificadas pelos detentores dos meios de produção e distribuição de conteúdos como atos de censura, que violam a liberdade de expressão e de imprensa.

A “liberdade” é rotineiramente invocada para indicar uma desejável abstenção de restrições à indústria da mídia. A desregulação é vista como o caminho a ser seguido, a única direção possível para a realização dos princípios fundadores dos direitos humanos. Segundo este ponto de vista, sem a ausência plena do Estado na organização e fiscalização dos negócios, não haveria liberdade possível (Zylbersztajn, 2008). 
A idéia do "livre mercado de idéias" vigorosamente presente na literatura anglo-saxã contemporânea ajuda a sustentar tal confusão e justificar a mínima interferência estatal, ignorando a desigualdade inerente ao mercado de mídia.

Na prática, o discurso jurídico dos agentes do mercado acerca da liberdade de expressão busca obstruir as tentativas de regulação das comunicações.

No Brasil, são abundantes as manifestações e ações políticas - e também jurídicas, pois algumas foram levadas aos tribunais - dos proprietários e representantes dos principais meios de comunicação em diversos momentos da história recente brasileira. Algumas destas manifestações, ocorridas especialmente a partir de 2003 após a posse do presidente Luiz Inácio Lula da Silva - por ter o governo, mesmo que timidamente, empreendido algumas iniciativas de regulação da mídia ${ }^{44}$ - são exemplares do fato de que o princípio jurídico da liberdade de expressão é atualmente utilizado como instrumento para a perpetuação de privilégios no campo da comunicação.

Tais casos são paradigmáticos, sendo sua exposição - com ênfase no discurso dos grupos econômicos (e, no caso do Brasil, também familiares) envolvidos - elemento necessário para compor a identidade do princípio jurídico invocado pelos proprietários e representantes dos principais veículos de comunicação social do país.

\section{1 - A Agência Nacional do Audiovisual}

Em 2004, o Ministério da Cultura elaborou proposta que visava estender a competência da atual Agência Nacional de Cinema (ANCINE) para todo o campo da indústria audiovisual brasileira, incluindo a televisão. O texto propunha a substituição da ANCINE pela Agência Nacional do Audiovisual (ANCINAV) e passou a ser duramente combatido por setores empresariais antes mesmo de seu envio ao Congresso Nacional, em especial pelas

\footnotetext{
${ }^{44}$ A afirmação não significa que este autor acredite que as políticas de comunicação implementadas pelo governo federal desde 2003 buscaram efetivamente criar um novo ambiente normativo para as comunicações, mais consistente e democrático. Pelo contrário: nos dois mandatos do presidente Lula pouco se avançou neste campo. As boas idéias não foram implementadas ou tiveram seu caráter deturpado.
} 
televisões comerciais abertas, pelos operadores e programadores de TV por assinatura e pelos representantes dos estúdios de cinema norte-americanos. Como porta-vozes da liberdade de expressão, posicionaram-se também os tradicionais partidos e grupos políticos conservadores, grandes jornais (e seus fiéis jornalistas), além de cineastas tradicionalmente favorecidos com o modelo de centralização privada na distribuição de recursos públicos.

Dentre os tópicos que despertaram a reação ao projeto estavam os que buscavam regular a distribuição dos recursos beneficiados por isenções fiscais regulamentados nas "leis de incentivo" e a cobrança de taxas sobre o faturamento do setor, que comporiam um fundo público para financiar a produção e distribuição de bens culturais de pouco ou nenhum interesse para os agentes do grande mercado cultural.

É razoável considerar na proposta produzida no âmbito do Ministério da Cultura não existirem traços em direção ao desejo de orientar política e ideologicamente os conteúdos audiovisuais - o mínimo de honestidade intelectual não comporta outra hipótese. Nos marcos do capitalismo contemporâneo, a proposta da ANCINAV sequer se aproximou do nível de intervenção encontrado em diversas experiências internacionais cujos valores democráticos são referência para o Brasil.

Dentre as diversas manifestações, um editorial da Folha de S. Paulo, embora não cite explicitamente o termo liberdade de expressão, é exemplar do comportamento da indústria da mídia face às tentativas de regulação de suas atividades. Referindo-se à proposta da ANCINAV - que, diga-se, pouco influiria em sua atividade, pois o foco do projeto era a indústria audiovisual -, assim a Folha de S. Paulo se posicionou:

Em um clássico do cinema, dirigido pelo cineasta norte-americano Stanley Kubrick, o ator Peter Sellers interpreta o memorável doutor Strangelove, numa corrosiva sátira ao militarismo anticomunista norte-americano dos tempos da Guerra Fria. Ele vive às voltas com seu braço mecânico, que insiste em se erguer inadvertidamente em saudação fascista, acentuando as tendências ideológicas da personagem. Também partidos de esquerda, mesmo convertidos às regras do convívio democrático, parecem às vezes ser vítimas do tique revelador de Strangelove: quando não se espera, eis que 
erguem o braço e deixam entrever os traços de suas surradas concepções autoritárias e centralizadoras [...]. ${ }^{45}$

Fernão Lara Mesquita, do Grupo Estado, utilizando-se das páginas do O Estado de S. Paulo, foi mais direto:

\begin{abstract}
"O 'pacote' da Ancinav é o mais violento atentado contra as liberdades civis desde a imposição da censura prévia à imprensa pelos governos militares. Trata-se de um ataque em três movimentos que tem por objetivos: ampliar os controles existentes sobre a radiodifusão no País, hoje limitados a um conjunto de preceitos constitucionais regulando as concessões de canais que jamais foram implementados e aos controles de fato exercidos pelos Tribunais Eleitorais sobre o jornalismo veiculado por mídia eletrônica, circunscritos aos períodos e ao tema pré-eleitorais; generalizar os temas passíveis de controle e ampliar o alcance desse controle para todo e qualquer tipo de suporte eletrônico; e, o mais importante e perigoso, concentrar o poder de controlá-los nas mãos de um grupo nomeado pelo presidente da República e lotado numa autarquia com mandato próprio, totalmente 'blindado' contra interferências externas [...].
\end{abstract}

Todas as normas e sanções são multiplicadas em alcance e em vigor, com exceção das que se referem a denúncias de mau comportamento de governantes [...]. Agora no poder, ao menos parte do partido acredita que não precisa mais oferecer as mesmas facilidades que tão bem soube usar a futuros desafiantes [...]. Quer o controle de toda a mídia eletrônica do País entretenimento e informação - só para si” ${ }^{46}$

O setor a ser regulado - o audiovisual - evidentemente, cerrou fileiras contra o projeto: abandonou o Congresso Nacional de Cinema (nome dado ao fórum que congregava todos os segmentos do audiovisual, dos grandes aos pequenos produtores) e criou uma nova organização, o Fórum pelo Desenvolvimento do Audiovisual e do Cinema (FAC), exclusivamente composto pelos setores que visavam impedir o avanço do projeto do Ministério da Cultura ${ }^{47}$.

\footnotetext{
${ }^{45}$ Folha de S. Paulo, Editorial: “A mão sinistra”, 8/09/2004.

46 "O golpe da Ancinav - I", Fernão Lara Mesquita: O Estado de S. Paulo, 19/09/04.

47 De acordo com a apresentação institucional da entidade, o FAC tem entre seus objetivos "atuar na luta pela liberdade de criação, expressão e comunicação; no estímulo à livre iniciativa”. Disponível em $<$ http://www.facforum.com.br/>
} 
De forma um tanto sinuosa, João Roberto Irineu Marinho, presidente das Organizações Globo e articulador maior do FAC, assim se manifestou:

\begin{abstract}
“[...] a Ancinav fala em editar normas e em regular, intervindo drasticamente no setor, mas não especifica regras. Num único ponto, menciona uma lei a ser enviada ao Congresso. Em todos os outros, afirma que regulará uma ampla gama de questões com base em enunciados vagos. Só é detalhista em relação a taxas e punições. Com a Anatel foi diferente: criada pela Lei Geral de Telecomunicações, ela não pode legislar, mas apenas fazer cumprir as regras previstas naquela lei. A Ancinav, não: como está, seria um cheque em branco. Esse não é o único viés autoritário do projeto". ${ }^{48}$
\end{abstract}

Um dos mais tradicionais porta-vozes do segmento empresarial, João Carlos Saad, presidente do Grupo Bandeirantes e da ABRA, também soou o alerta contra as “investidas" do governo federal:

“[Os ataques] Não vem de um setor, vem de vários setores. Vem de diversos ministérios. [...] vem de projetos no Congresso, vem do Ministério da Justiça [à época o MJ passara a discutir novas regras para a classificação indicativa]. A Ancinav é negócio ruim e feio. Querem enfraquecer o setor. [...] Nós deixamos rádio pirata e enchemos as empresas [legais] de impostos. Enfiamos goela abaixo horários eleitorais, campanhas políticas, tudo de graça. Depois não pode [propaganda de] cigarro, de bebidas. Então, no fundo, nós estamos querendo o quê? Destruir? Destruir o único setor que dá entretenimento e informação grátis para a população? [...] A Abra também vai se posicionar contra esse projeto ruim que o Ministério da Cultura fez. Aliás, eu queria saber o que o Ministério da Cultura está fazendo. Um bom jeito de disfarçar que a gente não está fazendo nada é atirar pedra na janela da casa do vizinho. É fazendo arruaça.

[...] Porque com isso a gente não pergunta o que é que está sendo feito no Ministério da Cultura. [...] Ele quer controlar os veículos todos. Por que vão controlar? Não quero ficar escravo de uma única opinião ou de censores estáveis. [...] Eu sinto que as pessoas fazem discursos maravilhosos sobre a

\footnotetext{
${ }^{48}$ Folha de S. Paulo, 2/9/2004.
} 
democracia, mas, na verdade, não gostam dela. É um sistema muito chato mesmo, mas é o menos ruim que a gente conhece. Mas tem gente que não gosta dele e por isso quer controlar tudo". ${ }^{49}$

Antonio Teles, executivo do mesmo Grupo Bandeirantes, delimitou o discurso do ponto de vista jurídico:

"[A Ancionav] é um risco à democracia, por sua disposição evidenciada de violar o caro valor da liberdade de expressão. Considero sinuosa a maneira como está nascendo a Ancinav. Não sabemos até onde se pretende ir [...]. O setor será intransigente na reação a propostas que ameacem violar a liberdade de expressão [...]. Somos contra o controle, a regulação e a fiscalização” [grifos nossos]. ${ }^{50}$

Parlamentares tradicionalmente alinhados aos interesses dos radiodifusores também foram ao ataque, caracterizando o anteprojeto de "nazista", que permitiria "o controle [pela nova agência] sobre o conteúdo e a autonomia de criação das emissoras de TV"51.

No mesmo período, a ABERT firmou posição "contrária a qualquer iniciativa que venha representar embaraço ou interferência estatal na criação artístico-cultural e nas liberdades de expressão e editorial". ${ }^{52}$

A ABRACI (Associação Brasileira de Cineastas) - que têm como membros eminentes conhecidos privilegiados na distribuição de verbas originárias de isenções fiscais -, também evocou os princípios da liberdade de expressão: "Em qualquer hipótese declaramos que estaremos sempre em defesa da liberdade de expressão, contra qualquer tipo de censura".

\footnotetext{
49 “Ancinav é ruim e feia”, entrevista concedida à Folha de S. Paulo, 22/11/2004.

${ }^{50}$ Audiência pública no Senado Federal, 12/10/2004.

${ }^{51}$ As afirmações são de Tasso Jeressati (PSDB-CE), em audiência pública realizada no Senado Federal. Na mesma ocasião, um dos mais eloqüentes foi o senador Hélio Costa (PMDB-MG): “O governo quer regulamentar um setor intimamente relacionado com as expressões artísticas". Folha de S. Paulo, 15/09/2004.

52 "Ancinav agita o audiovisual e o cenário político", Tela Viva News, 30/9/04.
} 
A filial brasileira da MPAA (Motion Pictures Association of America), entidade que representa os interesses dos grandes estúdios de cinema norte-americanos, fez ressurgir fantasmas estatizantes:

\footnotetext{
"A sensação que temos é de medo, de apreensão, a mesma que os investidores estrangeiros tiveram nos meses que precederam às eleições que colocaram Lula na presidência. Como naquele período, os investidores estão muito preocupados com o futuro das atividades do audiovisual no país. Teme-se um retrocesso e até mesmo a paralisação dos investimentos no setor". 53
}

O projeto para regular o setor do audiovisual formulado no âmbito do Ministério da Cultura, como se sabe, não suportou a artilharia da indústria nacional e internacional de mídia ancorada na associação entre os princípios da liberdade de expressão, de criação e de iniciativa, e acabou por submergir antes mesmo de ser enviado ao Congresso Nacional.

\section{2 - O Conselho Federal de Jornalismo}

O segundo caso paradigmático onde se manifestou de forma exemplar o uso do princípio jurídico da liberdade de expressão para evitar a regulação da atividade de comunicação social teve como estopim o envio pelo governo federal ao Congresso Nacional da proposta de criação do Conselho Federal de Jornalismo, em agosto de 2004.

Embora a proposta seja polêmica entre os próprios atores históricos que atuam em favor da democratização das comunicações ${ }^{54}$ é certo reconhecer, assim como no caso da Ancinav, a ausência de traços que pudessem atentar contra a liberdade de expressão ou à atividade jornalística. Experiências semelhantes são fartamente encontradas em países considerados democráticos, sem que isso tenha criado embaraços à liberdade de expressão.

\footnotetext{
53 Steve Solot, vice-presidente da MPAA para a América Latina: Jornal do Brasil, 24/09/2004

${ }^{54} \mathrm{O}$ Intervozes e a ABI - Associação Brasileira de Imprensa, por exemplo, embora não divergissem do mérito, foram contra a proposta. A Federação Nacional dos Jornalistas, por outro lado, é a formuladora e defensora do projeto.
} 
Apoiados em palavras inclusas no texto cuja leitura enviesada comporta múltiplos sentidos - como "orientar” e “disciplinar”, por exemplo -, a reação dos grandes empresários foi imediata.

A Folha de S. Paulo foi quem mais deu destaque à iniciativa, associando-a a uma tentativa de controle da imprensa pelo governo:

“[...] No caso do CFJ, a justificativa apresentada pelo ministro do Trabalho, Ricardo Berzoini, fala por si: 'Não há nenhuma instituição com competência legal para normatizar, fiscalizar e punir condutas inadequadas dos jornalistas'. O ministro, talvez inspirado no exemplo do líder cubano Fidel Castro, que ocupa lugar proeminente na galeria dos heróis petistas, não deixa dúvida sobre o que se pretende: independentemente de já existir legislação específica, cria-se uma instância de "fiscalização" ligada ao governo federal, que terá enorme potencial de ser instrumentalizada para coagir profissionais da imprensa.

[...] A idéia, que foi lamentavelmente sugerida pela própria Federação Nacional dos Jornalistas, ganha contornos ainda mais alarmantes ao se recordar que o governo recentemente pretendeu expulsar do país um correspondente do jornal 'The New York Times', além de solicitar, por intermédio do ministro Luiz Gushiken, da Secretaria de Comunicação, que a imprensa fosse menos 'negativista'. Não satisfeito, o mesmo Gushiken afirmou anteontem que o CFJ irá "proteger a sociedade $[\ldots . .]^{.} .{ }^{5}$

Fazendo referência à proposta, a revista Veja instigou analogias mais grotescas:

"Não há democracia que controle a imprensa. Nas ditaduras, no entanto, o lema do ‘todo o poder aos soviets’ está em alta. No Gabão, o ditador Omar Bongo, com o qual o presidente Lula desfilou em carro aberto pelas ruas de Libreville semanas atrás, criou um conselho, integrado por membros indicados pelo governo, cuja missão é punir jornalistas e órgãos de comunicação que publicam artigos caluniosos ou incorretos, segundo critérios dos governistas. Em 2002, dois jornais semanais foram acusados de 'minar a confiança no Estado e a dignidade de autoridades governamentais'. Em ditaduras mais estáveis, como Cuba e China, a

\footnotetext{
${ }^{55}$ Folha de S. Paulo, Editorial “A mão sinistra”, 8/09/2004.
} 
imprensa é um mero e desprezível apêndice do poder. Em Cuba, um departamento vinculado ao comitê central do Partido Comunista escolhe, revisa e corrige as reportagens veiculadas pelos órgãos de comunicação oficiais". ${ }^{56}$

A Associação Nacional de Jornais (ANJ), buscando qualificar a liberdade de imprensa como um direito fundamental, assim rotulou a medida:

"[...] Na prática, tribunais espúrios e corporativistas, com poderes para impedir jornalistas de exercer sua profissão e para suspender veículos de comunicação [...]. A liberdade de imprensa constitui direito inalienável e fundamental do ser humano, além de condição essencial para o exercício da cidadania". ${ }^{57}$

Os radiodifusores da ABRA utilizaram argumento retórico semelhante:

“Ao jornalismo deve ter assegurada a livre manifestação de pensamento e de crítica, sem censura, ainda que feita sob disfarce de atribuição a um órgão de classe”. 58

Parlamentares alinhados, uma vez mais, aumentaram o coro em defesa da liberdade. A passagem abaixo é emblemática e sintetiza o discurso hegemônico:

"De todos os muitos estragos que o presidente Lula e o PT vêm fazendo na consciência deste país, nenhum é tão grave como a tentativa atual de calar a imprensa. A era petista tem sido cirurgicamente eficaz no processo de corrosão da esperança dos brasileiros. [...] O conselho teria competência para estabelecer um 'código de ética' que iria prever as punições para condutas que fossem julgadas inadequadas, com penas que poderiam chegar à censura e até a cassação do registro profissional. Tudo no melhor rigor stalinista. O conselho de fato assumiria o controle da atividade de imprensa -uma atividade que tem como insumo essencial a liberdade de expressão e de informação, assegurada pela Constituição do Brasil.

\footnotetext{
${ }^{56}$ VEJA, 18/08/2004

57 Pronunciamento proferido por Francisco Mesquita Neto em 19/08/2004, na abertura de reunião da diretoria da ANJ. Folha de S. Paulo, 20/08/2004.

${ }^{58}$ Walter Ceneviva, Folha de S. Paulo, p.3, 14/09/2004.
} 
[...] Nenhum governo, em tempos de democracia, aplicou tal garrote nos jornalistas. Só mesmo em períodos de escancarado autoritarismo se ousou chegar a esse grau de intimidação. O que de mais parecido ocorreu no país foi o Departamento de Imprensa e Propaganda, o DIP, da era Vargas, que controlava com mão de ferro a produção audiovisual, os jornais e os jornalistas $[\ldots]$.

Por causa dessa ação livre da imprensa, um presidente da República foi mandado embora para casa e o Congresso cassou parlamentares corruptos. Graças ao mesmo jornalismo investigativo, que é um exemplar fruto da liberdade de imprensa, o Brasil ficou sabendo do carrossel de escândalos da era PT [...]. O PT e o presidente da República passaram a entender que o seu governo não pode ser criticado. Se a oposição faz oposição, é urucubaca. Se a imprensa denuncia, é futrica irresponsável. Logo, mordaça nela.

A democracia é o regime da tolerância, do debate, do conflito de opiniões e pontos de vista. Não é tentando calar a imprensa que vamos aperfeiçoar nossa democracia; muito menos ignorando a Justiça e a Constituição, que garantem à imprensa a voz livre, matéria-prima básica do seu exercício e da consciência democrática do país”. 59

O resultado da reação dos segmentos tradicionalmente privilegiados é de conhecimento geral: o projeto que criava o Conselho Federal de Jornalismo, assim como a ANCINAV, também submergiu antes mesmo de se tornar objeto de debate público qualificado.

\section{3 - Classificação Indicativa}

Em 2000, o Ministério da Justiça - à época sob o comando do Ministro José Gregori, ainda no governo FHC - editou Portaria que determinava regras para a Classificação Indicativa de programas de televisão e filmes exibidos no cinema. Cumprindo determinação constitucional $^{60}$, a iniciativa buscava dar eficácia ao Estatuto da Criança e do Adolescente

\footnotetext{
${ }^{59}$ José Carlos Aleluia (DEM-BA), Tendências e Debates, Folha de S. Paulo, 19/08/2009. À época, Aleluia era o líder do partido na Câmara dos Deputados.

${ }^{60}$ Ao estabelecer critérios para a classificação indicativa, o Ministério da Justiça apenas cumpre seu dever constitucional estabelecendo "meios que garantam à pessoa e à família a possibilidade de se defenderem de programas de rádio e televisão” (art. 220). Ainda no âmbito da Constituição Federal, a norma também cumpre a previsão de "colocar a criança e o adolescente a salvo de toda forma de negligência, discriminação, exploração, violência, crueldade e opressão” (art. 227).
} 
ao garantir a vinculação entre idade recomendada e horário de exibição dos programas televisivos. Por seguir padrões já aplicados em países reconhecidos por seus avanços democráticos, informação e boa-fé bastam para enxergar na iniciativa do Ministério da Justiça a busca pela efetivação do direito de crianças e do adolescentes crescerem e se desenvolverem em um ambiente social e culturalmente saudável ${ }^{61}$.

Desde 2000, a ABERT e, mais recentemente, a ABRA, questionaram a constitucionalidade da norma, alegando que a mesma violaria os artigos $5^{\circ}$ e o 220 da Constituição Federal (que qualificam a liberdade de expressão como um direito fundamental) ${ }^{62}$.

A partir de 2004, quando o Ministério da Justiça passou a discutir formas de dar efetividade à regra - até então as emissoras não eram obrigadas e divulgar a classificação indicada para o programa nem adaptar o horário de exibição à classificação do programa - as emissoras de televisão reagiram violentamente à regulação de sua atividade.

As televisões privadas, por meio de suas associações, conduziram a ofensiva para carimbar de "censura" a norma que visa garantir os direitos das crianças e adolescentes:

\section{Afirmou a ABERT:}

"Essa, sem dúvida nenhuma, é uma forma de censura incompatível com a Constituição Federal que garante a plena liberdade de expressão e não permite qualquer forma de intromissão na criação artística.

\footnotetext{
${ }^{61}$ Na prática, a Classificação Indicativa é uma recomendação pedagógica que disponibiliza aos pais, mães ou responsáveis pela educação das crianças, informações necessárias sobre o conteúdo televisivo, indicando as faixas etárias às quais determinado programa é adequado. "Classificar”, assim, pressupõe unicamente aplicar sobre as obras critérios que recomendam horários para exibições de cenas de sexo e violência. Lembre-se, ainda, que programas jornalísticos não fazem são fazem parte dos conteúdos classificáveis, podendo ser exIbidemos em qualquer horário. Alberto Dines, editor do Observatório da Imprensa, um liberal exemplar, dirime qualquer dúvida sobre caráter da CI: “Jornalistas mal informados e emissoras de TV de má-fé estão tentando confundir a opinião pública alegando que a decisão do Ministério da Justiça de classificar a programação de TV equivale à implantação da censura”. "Classificação de programa não é censura”, acessado em 02/05/2006.

${ }^{62}$ Acionado pela ABERT e pelo Partido Popular Socialista (PPS), o STJ suspendeu temporariamente, por duas vezes, a vigência da classificação indicativa. “Organizações protestam contra decisão do STJ”, em Observatório do Direito à Comunicação, acessado em 12/04/2009.
} 
No Brasil a gente não precisa ter aqui o sistema de censura, de imposição de limite de liberdade de expressão [...]. O medo da censura é um medo que tem que estar muito presente na gente porque a censura é incidiosa, ela não se apresenta nunca como instrumento de opressão, ela vem sempre de mansinho, em defesa da família, dos bons costumes, da sociedade, mas quando ela se instala, ela se instala como instrumento de opressão. E é contra esse instrumento de opressão que a Constituição federal consagrou a liberdade de expressão e a gente está aqui para zelar por ela”. ${ }^{63}$

\section{E a ABRA:}

“[A Classificação Indicativa] é uma tentativa grave, é uma tentativa importante de estabelecer a censura na televisão. É importante porque ela emprega uma palavra que em 'juridiquês' significa obrigatória. A portaria implica em que quem escolhe o horário dos programas de televisão é o ministro da Justiça. E é preciso que nós nos ponhamos contra essa interferência do ministro da Justiça na organização da programação da televisão no Brasil.

Os pais é que têm a obrigação e o direito de controlar o que vai na televisão. Em hipótese alguma, nem o ministro, nem o estamento da burocracia do governo. O governo não sabe escolher horário de programa de televisão e o governo não tem direito de escolher". ${ }^{64}$

Embora a determinação para a exibição da faixa etária para a qual é destinado o programa e sua relação com o horário ser exibido tenham sido mantidos, o resultado da ofensiva contra a nova classificação indicativa deu resultado: a regra já expedida foi alterada, e a classificação passou a ser, na verdade, uma auto-classificação, feita pela própria emissora, reduzindo significativamente sua eficácia como norma de proteção à dignidade humana.

Este episódio, que culminou com a edição da Portaria 1.220/07, é revelador do poder político das Organizações Globo. Pouco comentado inclusive em círculos políticos e

\footnotetext{
${ }^{63}$ Antonio Cláudio Ferreira Neto, representante da ABERT, no programa Roda Viva da TV Cultura, em 25/06/2007. "Memória Roda Viva”, disponível em <http://www.rodaviva.fapesp.br/materia/108/entrevistados/debate_sobre_classificacao_indicativa_2007.htm>

${ }^{64}$ Walter Ceneviva, representante da ABRA, no programa Roda Viva da TV Cultura, em 25/06/2007.

"Memória Roda Viva”, disponível em

<http://www.rodaviva.fapesp.br/materia/108/entrevistados/debate_sobre_classificacao_indicativa_2007.htm>
} 
acadêmicos vinculados ao tema da comunicação, é síntese da relação entre radiodifusão e poder político: ao não obter sucesso completo na missão de evitar regras para a classificação indicativa, a empresa patrocinou, sem alarde, a aprovação da mudança do fuso horário da Região Norte, evitando a necessidade de alguns poucos ajustes em sua grade de programação $^{65}$.

\section{4 - Incentivo à programação nacional}

A partir de 2007, a Comissão de Ciência e Tecnologia da Câmara dos Deputados passou a despender boa parte de suas energias na discussão do Projeto de Lei 29/2007, que visava alterar a regulamentação o setor de TV por assinatura no país, unificando a legislação dos três serviços hoje existentes - por cabo, satélite e microondas.

Apesar de sua justificativa inicial ser a permissão para que as empresas concessionárias de telefonia fixa prestem serviços de TV a cabo, o projeto acabou incorporando mecanismos para ampliar a diversidade e a pluralidade do conteúdo ofertado aos assinantes do serviço. Um desses instrumentos, o estabelecimento de cotas para conteúdo audiovisual nacional e independente, foi alvo de uma agressiva campanha por parte da Associação Brasileira de TVs por Assinatura (ABTA). Com a veiculação de peças publicitárias em suas operadoras associadas cujo slogan era "Liberdade na TV", afirmava a ABTA ser a proposta uma violação à "liberdade de escolha dos assinantes"66.

Nota divulgada pela assessoria de imprensa da ABTA, na ocasião do lançamento da referida campanha, sintetiza o discurso adotado pela organização:

“[...] o projeto é um retrocesso e um passo ao autoritarismo, uma vez que permitiria o controle dos meios de comunicação.

\footnotetext{
${ }^{65}$ Com isso, a diferença do horário do Acre e de 46 municípios do Amazonas em relação ao de Brasília caiu de duas para uma hora. Já o Pará passou a ter o mesmo fuso horário de Brasília. A lei, de autoria do senador Tião Viana (PT-AC), foi aprovada no Senado dias após a entrada em vigor dos dispositivos da Portaria 1.220/07 que determinam que as emissoras de TV adaptem suas transmissões aos diferentes fusos horários. ${ }^{66}<$ http://www.liberdadenatv.com.br/entenda.aspx $>$
} 
[...] Isto praticamente isola o Brasil do resto do mundo, pois limita a livre circulação de bens culturais com base em seu país de origem. Este projeto é um passo ao autoritarismo, já que permite o controle dos meios de comunicação, e um ataque à liberdade garantida como direito fundamental no Art. $5^{\circ}$ da nossa Constituição Federal.

[...] Hoje, a restrição se dá por conta do país de origem. E amanhã? Alinhamento político? Que outro critério poderia ser adotado a partir daí? E se a ameaça hoje é no conteúdo veiculado na TV por assinatura (que por princípio deveria ser uma escolha individual do assinante, já que não se trata de exibição em plataforma de regime público), o que impediria futuras restrições à Internet? Aos celulares? Aos telefones? [...] " 67

Quando da conclusão desta dissertação, PL 29/2007 ainda não havia sido aprovado no Congresso Nacional. A previsão, se tudo seguir o rumo usual - onde somente as normas de interesse do mercado avançam -, é que as operadoras de telefonia fixa recebam autorização para entrar no mercado de TV a cabo, mas as quotas para conteúdos nacionais e independentes sejam retiradas do escopo do projeto.

\section{5 - A regulação da publicidade comercial}

De todos exemplos paradigmáticos, o mais forte - por associar diretamente os princípios da liberdade expressão e da livre iniciativa - é o empreendido em aliança do setor de comunicação social com os segmentos econômicos envolvidos com a atividade publicitária.

Desde a década de 70 , quando a atuação dos movimentos de defesa do consumidor começou a resultar em iniciativas governamentais de regulação do conteúdo das propagandas comerciais, o segmento do mercado publicitário se uniu em torno do Conselho Nacional de Auto-Regulação Publicitária (CONAR) ${ }^{68}$, buscando impor um sistema baseado

\footnotetext{
${ }^{67}$ Associação Brasileira de TV por Assinatura, acessado em 4/12/2007, disponível em: <http://www.abta.org.br/Imprensa/Pressreleases/tabid/202/ctl/ViewContent/mid/571/ItemID/1770/Default.asp $\mathrm{X}>$

${ }^{68}$ Atualmente, o CONAR assim define sua missão: “O CONAR lidera a luta da indústria da propaganda na defesa da liberdade de expressão comercial. Trata-se de uma luta permanente, que começa no monitoramento minucioso da opinião pública e seus eventuais desdobramentos em centenas de iniciativas do Poder Público, em sua grande maioria visando limitar um direito constitucional. Nunca é demais lembrar que,
} 
na (não) regulação do mercado pelos próprios agentes econômicos privados, modelo conhecido como auto-regulação.

A partir de então, a proteção aos consumidores tem se tornado cada vez mais ampla, o que implica uma constante tensão com os interesses do setor publicitário. Esse conflito aflorou novamente no curso dos debates que envolveram elaboração da Constituição Federal de 1988, momento em que o CONAR coordenou uma campanha feita em nome do “movimento nacional pela livre iniciativa” e cujos principais lemas eram: "não há liberdade política sem liberdade econômica" e "o sistema da livre iniciativa é a base da democracia" (Costa e Costa, 2008).

Apesar desses esforços, a pressão do movimento de defesa dos consumidores conseguiu fazer com que o texto constitucional determinasse que "a propaganda de tabaco, bebidas alcoólicas, agrotóxicos, medicamentos e terapias estará sujeita a restrições legais e conterá, sempre que necessário, advertência sobre os malefícios decorrentes de seu uso” (art. 220, $\S 4^{\circ}$, II). No bojo deste mesmo processo foi aprovado o Código de Defesa do Consumidor (Lei 8.078/90), marco normativo também fortemente influenciado pela atmosfera progressista da Constituinte.

As "derrotas" sofridas pelos meios de comunicação e pelo CONAR - inevitável pelo espírito que tomou conta da produção do texto constitucional e do Código de Defesa do Consumidor - não alterou o posicionamento do setor, que manteve e até aumentou sua incidência na esfera política.

Em 2000, por iniciativa do Ministério da Saúde, o Brasil voltou a discutir medidas para restrição da propaganda de cigarros, proibindo inclusive o patrocínio de eventos esportivos e culturais. Na ocasião e pela primeira vez, o CONAR defendeu publicamente o conceito de liberdade de expressão comercial.

no momento, tramitam no Congresso Nacional mais de duzentos projetos de lei que, de alguma forma, visam cercear a liberdade de anunciar [...]. Nessas oportunidades, o CONAR, por meio de seus representantes, procura defender de forma serena e objetiva, sempre amparado por pesquisas e pareceres, o princípio constitucional da liberdade de expressão comercial”. Disponível em:

<http://www.conar.org.br/html/boletim/defesa_liberdade.htm> 
A partir de 2005, a Agência Nacional de Vigilância Sanitária (ANVISA) passou trabalhar com mais intensidade para regular a atividade publicitária de bebidas alcoólicas e alimentos não-saudáveis, buscando sobretudo proteger crianças e adolescentes. Simultaneamente, intelectuais (em especial psicólogos e pedagogos) e organizações da sociedade civil de diversas matrizes e origens passaram a defender restrições à publicidade dirigida ao público infantil, buscando, à semelhança de diversas experiências internacionais, proteger as crianças de práticas antiéticas e abusivas.

Como resposta, o termo liberdade de expressão comercial passou a fazer parte do vocabulário cotidiano do setor publicitário, sendo utilizado de forma recorrente como argumento retórico para deter as iniciativas de regulamentação do exercício da comunicação publicitária de determinados produtos, notoriamente de tabaco, bebidas alcoólicas, medicamentos, alimentos não saudáveis e a destinada ao público infantil.

Contra a ofensiva da Anvisa uniram-se anunciantes, agências de publicidade e empresas de comunicação social. Para defendê-los no Congresso Nacional, 198 deputados federais (38,6\% do total) e 38 senadores (47\%) criaram a Frente Parlamentar Mista de Comunicação Social.

O auge da campanha contra qualquer regulação da atividade publicitária ocorreu no $4^{\circ}$ Congresso Brasileiro de Publicidade, realizado em 2008. No documento final do evento, foram destacados a denúncia e o repúdio dos congressistas a "todas as iniciativas de censura à liberdade de expressão comercial, inclusive as bem intencionadas”.

Na abertura do evento, Roberto Civita, proprietário do Grupo Abril, assim se pronunciou:

“Como disse há muitos anos o grande publicitário norte-americano Bruce Barton: 'O direito do povo de escolher livremente seus alimentos, suas roupas, seus livros, suas casas é a própria essência da democracia. Não é por acidente que, no regime totalitário, não há propaganda comercial. Desde o momento em que se permite ao povo escolher livremente a 
qualidade, o estilo e o tipo de artigos que cercam sua vida, não se pode mais impedi-lo, permanentemente, de caminhar para o supremo objetivo que é a escolha de seus governantes e do seu regime de vida'.

Para exercer e manter esses direitos é condição indispensável que a informação também seja livre, como, aliás, garante a nossa Constituição.

[...] Os meios de comunicação não subsistiriam sem a publicidade, que não existiria se não houvesse competição, que não teríamos sem um sistema de mercado livre, que depende - fechando esse círculo virtuoso e admirável da democracia e da liberdade para garanti-lo.

Assim, a publicidade é um dos pilares da imprensa livre e independente. Sem ela, seria impossível manter a quantidade e pluralismo dos meios de informação que divulgam idéias, defendem pontos de vista diferentes, denunciam a corrupção, estimulam o debate político e assim se tornam, nas palavras de Ruy Barbosa, 'as vistas da nação'. Sem publicidade, repito, não existiria uma imprensa vigorosa, uma imprensa que - sabemos todos e os ditadores mais do que nós - é o alicerce do primado da lei e de uma sociedade aberta.

Apesar disto, e por mais estranho que possa parecer, continuam surgindo ameaças às liberdades conquistadas e garantidas pela Constituição. Um exemplo é o excesso de legislação que o Congresso Nacional tenta impor à publicidade. Tramitam hoje mais de 200 proposições para introduzir travas onde não deveriam existir.

São projetos que, de diferentes maneiras, buscam estabelecer restrições crescentemente mais rigorosas à liberdade de expressão comercial. Atenção, por favor: não são restrições à produção, distribuição, consumo ou mesmo à extração de carga tributária adicional de uma determinada lista de produtos. Não. Trata-se apenas de impedir que se faça a publicidade desses produtos fabricados, comercializados e consumidos legalmente, como se, sem a publicidade, o problema percebido deixasse de existir.

Não se pode admitir que o desejo de proteger as pessoas contra si mesmas ou de sanear todos os males da sociedade com novas leis leve a absurdos como o da ANVISA (Agência Nacional de Vigilância Sanitária) ter decidido, por conta própria, legislar sobre a publicidade de bebidas alcoólicas e de medicamentos [...]. 
Para mim, a melhor resposta que já encontramos nesta frente espinhosa é aquela do CONAR. O Conselho de Auto-Regulamentação Publicitária já nos dá, há 30 anos, uma esplêndida demonstração de que os publicitários, veículos, anunciantes e, finalmente, o cidadão, têm juízo. A auto-regulação publicitária é um desses casos de triunfo da cultura de boa fé que poderia ser apresentada como um brilhante exemplo de convivência pacífica e democrática de interlocutores que, ao enfrentarem problemas comuns ou terem interesses conflitantes, sentam à volta de uma mesa e resolvem suas pendências, em benefício de todos e da comunidade.

Numa sociedade que ainda guarda na memória os tempos negros da ditadura e da censura, o futuro depende de que o exercício dessas liberdades por todos nós, como jornalistas, publicitários, homens de comunicação, leitores, eleitores e cidadãos seja dosado pelo bom senso, pelo autocontrole e, principalmente, pela responsabilidade. Só assim será reforçado esse círculo virtuoso da democracia, da livre iniciativa e da liberdade de imprensa - fundamental para o país melhor com que todos nós sonhamos”. ${ }^{69}$

Vale transcrever, também, longo trecho do emblemático discurso de João Roberto Marinho, apoiado de forma integral no vocabulário dos direitos humanos:

"Há valores que são absolutos: em qualquer sociedade, em qualquer continente, em qualquer época. Sem eles, o homem não se realiza totalmente. Cito apenas dois, mutuamente dependentes e que nos dizem respeito de perto: a democracia e a liberdade de expressão. Falando de um, estarei falando do outro.

Desde a Revolução Francesa de 1789, com a Declaração de Direitos do Homem e do Cidadão, a liberdade de expressão está consagrada. Dizia aquele documento de importância histórica incalculável em seu artigo 11: 'A livre comunicação das idéias e das opiniões é um dos mais preciosos direitos do homem. Todo cidadão pode, portanto, falar, escrever, imprimir livremente, respondendo, todavia, pelos abusos desta liberdade nos termos previstos na lei’.

Em 1948, a Declaração Universal dos Direitos Humanos, da ONU, dava nova redação ao tema: 'Toda pessoa tem direito à liberdade de opinião e

${ }^{69}$ O Globo, 15/07/2008. 
expressão; este direito inclui a liberdade de, sem interferências, ter opiniões e de procurar, receber e transmitir informações e idéias por quaisquer meios e independentemente de fronteiras'.

Em 1994, a Declaração de Chapultepec, da qual o Brasil é signatário, foi mais simples, mas não menos verdadeira: 'Não há pessoas nem sociedades livres, sem liberdade de expressão e de imprensa’.

Esse pensamento clássico deixou raízes em todos nós: em mim, em vocês, nos políticos de uma maneira geral. A Constituição de 1988 estabelece amplas garantias à liberdade de expressão, em vários momentos. Cito aqui os mais eloqüentes deles: o inciso nono do artigo $5^{\circ}$ : 'É livre a expressão da atividade intelectual, artística, científica e de comunicação, independentemente de censura ou licença.' E o inciso segundo do artigo 220: 'É vedada toda e qualquer censura de natureza política, ideológica e artística’.

Apesar disso, hoje em dia temos visto muitas tentativas de relativizar a liberdade de expressão. Quando não vêm de segmentos francamente antidemocráticos, essas iniciativas podem ser explicadas por uma propensão a ver o cidadão como alguém que necessita de tutela, incapaz de discernir entre o bem e o mal, entre o certo e o errado, entre o ético e o sem escrúpulo.

[...] Quando aqueles que deveriam zelar pela liberdade passam a querer enquadrá-la, resumindo as opções de escolha, o resultado é sempre a tutela, ou seja a infantilização dos cidadãos. Considerando-se conhecedores privilegiados da moral vigente ou imaginando que sabem o que é o bem comum, essas pessoas acabam usurpando um poder que os cidadãos não lhes deram. É preciso ter em mente que não há democracia com tutela e que a liberdade de expressão jamais é excessiva [...].

O que vemos, porém, mais e mais, é uma sanha reguladora, em que alguns poucos acreditam que podem julgar por muitos. Mas, além de lutarmos no campo jurídico, nós, jornalistas, precisamos estar unidos para denunciar tais manobras com veemência. Só assim ataques desse tipo serão desencorajados.

Às vezes, porém, cada setor, cada mídia, preocupa-se mais com as ameaças diretas que enfrenta e deixa de dar atenção a problemas que aparentemente 
atingem apenas outros setores. É um erro. O limite à liberdade de um é um limite para todos.

É o caso das ameaças à publicidade.

Talvez não haja setor mais adulto no Brasil do que a propaganda. A prova disso é o CONAR, uma experiência pioneira de auto-regulamentação, com o objetivo de coibir abusos. Mas não adianta: uma certa mentalidade não consegue ver a propaganda como o que ela é de fato: um motor fundamental para o desenvolvimento de um país, que promove a competição, diminui os preços e aumenta a qualidade dos produtos. É ela que informa o público, tentando convencê-lo das qualidades de um bem ou serviço, e é o público que, diante das muitas escolhas, conscientemente decide consumir aqueles que mais correspondam às suas expectativas. Mas, na visão paternalista, o consumidor é um desavisado que precisa ser protegido.

Surgem, então, propostas de se proibir a propaganda: de alimentos, bebidas e um mundo de coisas.

É preciso confiar no indivíduo. Não se consegue mudar hábitos com menos, mas com mais propaganda. O impulso de se tutelar o cidadão também acontece com um mecanismo que, na prática, se parece muito com a censura.

A Constituição de 88 estabeleceu que nenhuma forma de censura teria mais vez em nosso país. Foi uma resposta à ditadura, quando uma minoria ditava o que os brasileiros podiam ou não ver em suas TVs.

Por que colocar tudo isto em risco? É preciso que se diga claramente: o cerceamento à liberdade de expressão não ameaça apenas a audiência ou a vida financeira das emissoras; a ameaça mais cruel para o país é a redução da qualidade criativa de nossa teledramaturgia, até aqui um setor que só trouxe reconhecimento internacional para o nosso país. E não são poucos os exemplos.

Se eu pudesse resumir o que disse aqui, eu diria: não existe democracia sem liberdade plena de expressão. É o exercício dessa liberdade que nos faz amadurecer como cidadãos. E são cidadãos amadurecidos, e bem 
informados, que tornam possível um país culturalmente vigoroso, economicamente forte e socialmente mais justo" ${ }^{70}$

Melhor exemplo não há.

Como resultado da ofensiva contra a regulamentação da atividade publicitária, embora o debate sobre este tema tenha crescido, nenhuma outra iniciativa nessa direção prosperou para além dos limites impostos à publicidade de cigarros vigentes desde o início da década.

${ }^{70}$ O Globo, 15/07/2008. 


\section{0 - SÍNTESE: EM BUSCA DA RECOMPOSIÇÃO DA LIBERDADE}

Os exemplos apresentados - que certamente poderiam ser complementados por outros, como a reação dos principais grupos de mídia em 2008, quando fiéis da Igreja Universal do Reino de Deus ingressaram com 89 ações judiciais contra a Folha de S. Paulo e sua repórter, Elvira Lobato ${ }^{71}$ - apresentam um panorama bastante claro da forma como os proprietários dos grandes meios de comunicação nacionais recorrem ao princípio jurídico da liberdade de expressão para evitar qualquer forma de incidência da sociedade sobre suas atividades, garantindo um ambiente altamente desregulado cuja marca essencial é a ausência de instrumentos de controle público.

As reformas combatidas pelo empresariado brasileiro já foram há muito implementadas em democracias liberais, ancorados no direito à liberdade de expressão; no Brasil, inversamente, tais diretrizes regulatórias não prosperam apoiadas justamente na idéia de que tal liberdade, para que seja garantida em sua plenitude, deve ser compreendida como a abstenção absoluta do Estado na dinâmica econômica do setor. É, por certo, uma anacronia dos nossos tempos.

Este discurso se apóia, entre outros aspectos, na confusão estabelecida entre liberdade de expressão e liberdade de imprensa - com variáveis como liberdade de expressão artística, liberdade de criação, liberdade de anúncio, liberdade jornalística, entre outros. É rotineiro encontrar não só a utilização das duas expressões - liberdade de expressão e liberdade de imprensa - como equivalentes, mas também o deslocamento da liberdade de expressão do indivíduo para a "sociedade" e, desta, implicitamente, para os "jornais", sejam eles impressos ou audiovisuais.

Não há, contudo, confusão que resista à boa-fé intelectual.

\footnotetext{
${ }^{71}$ Na ocasião, a ANJ divulgou nota na qual afirmou: “O que os autores dessas ações pretendem não é restabelecer sua honra ou a verdade, mas constranger uma empresa jornalística no seu dever de livremente informar a sociedade [...]. É uma tentativa espúria de usar o Poder Judiciário contra a liberdade de imprensa, ameaçar o livre exercício do jornalismo e privar o cidadão do direito de ser informado”.
} 
A liberdade de expressão se refere a uma liberdade individual e ao direito humano fundamental à expressão. Já a liberdade de imprensa, é a liberdade de empresas comerciais - a imprensa ou a mídia - de publicarem o conteúdo que consideram "informação jornalística”. Embora a liberdade de imprensa possa ser auxiliar à liberdade de expressão, não se sobrepõe e nem a ela se equivale.

Comentando o Artigo 19 da Declaração Universal dos Direitos Humanos, Kaarle Nordenstreng faz a distinção essencial: "o sujeito dos direitos humanos e das liberdades fundamentais não é uma instituição chamada a imprensa ou a mídia, mas um ser humano individual". E prossegue: "A frase 'liberdade de imprensa' é enganosa na medida em que ela inclui uma idéia ilusória de que o privilégio dos direitos humanos é estendido à mídia, seus proprietários e seus gerentes, ao invés de ao povo para expressar sua voz através da mídia". E mais à frente: "Nada no Artigo 19 sugere que a instituição da imprensa tem qualquer direito de propriedade sobre esta liberdade" (Apud Lima, V., 2009).

Exemplo recente dessas distorções pode ser constatado nas poucas linhas de anúncio de meia página que a Associação Nacional de Jornais fez publicar em vários jornais por ocasião de seus 30 anos, em agosto de 2009:

Título: Sem liberdade de imprensa esta seria a única testemunha. [A imagem é de um rato que assiste a uma suposta cena de corrupção sendo praticada por dois homens iluminados por faróis de automóveis]. Texto: Nos últimos 30 anos, o país passou por mudanças decisivas. E os jornais foram os olhos e os ouvidos de milhões de pessoas durante o processo. Graças ao trabalho da imprensa, o cidadão teve acesso a informações preciosas que se tornaram o que mais interessa numa democracia: opinião. Assinatura: ANJ. Há 30 anos lutando pelo que a sociedade tem de mais valioso: a liberdade de expressão.

O sujeito da liberdade de expressão, assim, deixa de ser o indivíduo e passa a ser uma difusa "sociedade"; os jornais são genericamente identificados com "os olhos e os ouvidos de milhões de pessoas" e a imprensa como formadora desinteressada da opinião, "o que 
mais interessa na democracia". Por fim, liberdade de imprensa e liberdade de expressão são implicitamente consideradas como equivalentes.

Referindo-se à liberdade de imprensa, John Nerone (1995) traça a diferença entre os séculos XVII e XIX e a imprensa do século XXI, abordando a mesma diferença conceitual. Vale a longa citação:

Liberdade de imprensa fazia razoável bom senso como direito natural. Embora o cidadão comum não nasça com uma impressora (ao contrário, por exemplo, da consciência ou da palavra), ainda assim era relativamente fácil justificar liberdade de imprensa como uma extensão destas outras formas de liberdade de expressão. Da mesma forma, num mundo de indivíduos atomizados, liberdade de imprensa fazia tolerável bom senso como um direito utilitário. Deus não criou necessariamente esta situação, mas as pessoas concordavam que indivíduos livres para imprimir suas idéias estariam mais bem preparados para o autogoverno. Em ambas essas versões da filosofia política liberal, liberdade de imprensa é um direito do indivíduo, como liberdade de expressão (speech) ou consciência; 'a imprensa' é nada mais do que a impressora (printing press), o equipamento real da expressão impressa. Isto não é mais o que `a imprensa' significa.

Hoje a imprensa é compreendida como sendo uma instituição - uma coleção de organizações noticiosas (news organizations) que guardam a mesma relação com 'o povo' como, por exemplo, a Bolsa de Valores de New York. Ninguém pode fingir que a Bolsa de Valores de New York é o povo. Nem a imprensa pode ser equiparada com o povo. Por que devemos então falar de liberdade de imprensa? Na política liberal, entidades empresariais (corporate entities) têm liberdade somente como pessoas fictícias (i.e., indivíduos) ou como depositárias de liberdades individuais de pessoas reais. É difícil pensar a imprensa como uma pessoa fictícia. E, se a imprensa é a depositária das liberdades individuais de seus leitores, então ela certamente tem que ter responsabilidades. Ela não está mais livre para trabalhar contra os interesses de seus leitores do que uma empresa publicamente controlada está livre para trabalhar contra os interesses de seus acionistas. Em termos intelectuais, então, a noção liberal clássica de liberdade de imprensa já havia deixado de fazer sentido na década de 50 . 
Assim, não parece haver dúvida que a liberdade de imprensa clássica como extensão da liberdade de expressão individual não guarda qualquer relação com o que se pretende por liberdade de imprensa no mundo dos grandes conglomerados globais de comunicação e entretenimento, muitos deles, vale lembrar, com orçamentos superiores àqueles da maioria dos Estados membros das Nações Unidas.

Há mais de 15 anos, Comparato (1994), já sentenciava:

\begin{abstract}
A originária liberdade de expressão ou de imprensa acabou esbarrando, na sociedade de massas, num obstáculo técnico insuperável: o acesso aos meios técnicos de difusão das mensagens. A sociedade de antanho era a comunidade do face a face. A sociedade contemporânea é a da comunicação simbológica ou telemática: as relações já não são pessoais, mas globais. A liberdade de expressão hodierna só se concebe para aqueles que têm meios - materiais e pessoais - de montar instituições de teletransmissão das mensagens: os controladores das empresas de imprensa, rádio e televisão (1994, p. 65).
\end{abstract}

A radicalização desta mesma lógica que busca gerar confusão entre o direito fundamental à expressão e o direito das empresas privadas que atuam no setor das comunicações se materializa na tentativa de forjar a aceitação - como se costume jurídico fosse - da liberdade de expressão comercial como um direito humano.

\title{
Considera-se, neste caso e uma vez mais, que honestidade intelectual basta para colocar um fosso entre a liberdade de expressão e a atividade de anunciar produtos em veículos de comunicação.
}

A liberdade de expressão comercial, ao transformar em equivalentes dois tipos totalmente distintos de informação - a publicitária e a jornalística - “apropriou-se, sem mais, da idéia de liberdade de expressão como se a mídia, anunciantes e agências de publicidade fossem os legítimos representantes do direito individual e coletivo contra a 'censura' e a 'sanha regulatória’ exercidas pelo o Estado” (Lima, V., 2008). 
Decorrem dessas considerações a conclusão que, no Brasil, o princípio jurídico da liberdade de expressão foi capturado pelos proprietários dos meios de comunicação, que impõe uma interpretação deturpada de seu significado original, resignificando-o de forma a esvaziá-lo e determinar que, hegemonicamente, seja compreendido como a ausência absoluta de instrumentos que regulem a atividade e imponham restrições a seus interesses econômicos. A ameaça à liberdade - em particular à liberdade de expressão e à liberdade de imprensa - tem sido identificada no espaço público como vindo exclusivamente do Estado, mesmo que estejamos vivendo em um Estado de Direito, no (pleno) funcionamento das instituições democráticas.

Já o princípio jurídico do direito à informação, desde seu reconhecimento no plano normativo, nunca logrou avançar seu escopo para além do direito à receber informações, que pode ser satisfeito na medida em que a liberdade de imprensa é respeitada e exercida. Como conseqüência, o direito à informação não conseguiu se impor como um determinante jurídico ou político, se constituindo como um princípio acessório nas discussões públicas sobre as determinações regulatórias do setor.

O resultado dessa hegemonia é clara: no Brasil, a estratégia discursiva simultaneamente política e jurídica - dos proprietários dos grandes meios de comunicação comerciais, prevaleceu: o marco regulatório nacional se moveu historicamente à mercê de interesses privados, ora nacionais, ora internacionais. Como comprova de forma categórica o relato da história regulatória dos serviços de comunicação, a circulação de informação, à exceção de períodos episódicos, sempre foi controlada por monopólios e oligopólios privados. Seus proprietários mantiveram, e ainda mantém, influência decisiva na vida política nacional, perpetuando, no plano normativo, um ambiente altamente favorável à maximização de seus lucros e a defesa de interesses políticos determinados.

No setor das telecomunicações - marcado historicamente pelo debate regulatório sob a perspectiva econômica e industrial -, a estratégia discursiva dos conglomerados, embora não seja foco desta dissertação, mantém similaridade à dos proprietários de emissoras de 
radiodifusão e de meios gráficos. Para evitar uma maior regulação estatal e interditar o debate sobre as políticas públicas setoriais, as empresas - de capital nacional ou internacional, monopolistas em setores específicos - buscam associar as iniciativas estatais de intervenção na atividade econômica a possíveis fantasmas estatizantes e autoritários, vinculando o princípio da liberdade de iniciativa econômica à realização da democracia e da dignidade humana.

Das três teorias relativas à liberdade apresentadas por Barendt (1985), portanto, não podem restar dúvidas: é hegemônica a percepção de que a liberdade de expressão é um direito eminentemente individual face ao Estado.

Como resume Mattelart (2009):

O quadro geopolítico no qual a liberdade de expressão foi codificado favoreceu a tese liberal da versão americana, também chamada de doutrina do free flow of information, já que foi introduzida nos textos e na interpretação dessa cláusula da Carta das Nações Unidas: "facilitar a livre circulação de idéias através da palavra e da imagem”. Esta concepção seletiva da liberdade de expressão tornou-se performática e materializou-se nas estratégias e nas políticas de desenvolvimento (2009, p. 36-27).

Dessa forma, apesar de comportar múltiplas interpretações, tem prevalecido a perspectiva de que, para se realizarem, tais princípios requerem a não interferência absoluta do Estado na regulação dos meios de comunicação. Embora no plano político exista uma permanente “disputa” pelo conceito de liberdade de expressão que permita argumentar ser tal liberdade um conceito mais amplo (que abarca a imposição de promover a diversidade e a pluralidade), é certo que os interesses privados obtiveram sucesso em impor, no âmbito regulatório, uma interpretação do termo que melhor atende a seus interesses. Foi apoiada nesses discursos que se moveram as disputas políticas sobre os modelos regulatórios e, conseqüentemente, a privatização do espaço público.

Como resultado, se nas revoluções do Século XVIII as aspirações liberais se materializavam a partir da vontade individual de se fazer presente na esfera pública, 
hoje este princípio jurídico não mais dá conta de totalizar as aspirações pela dignidade humana.

O direito à comunicação, assim, se apresenta, entre outras características, como a superação desta limitação historicamente imposta à compreensão dos princípios da liberdade de expressão e do direito à informação. 


\section{1 - DIREITO À COMUNICAÇÃO: HISTÓRICO E CONTEÚDO}

A história das formulações teóricas acerca do direito humano à comunicação - como bem descreveram alguns jovens autores como Aline Lucena Gomes (2007) e Eduardo Ariente (2008) - está ligada ao processo de mudança no perfil da UNESCO no Pós Guerra, resultado do processo de descolonização e subdesenvolvimento econômico. A entrada massiva de outros Estados no sistema das Nações Unidas provocou, senão uma mudança de ordem temática, pelo menos uma inversão de objetivos. Estabeleceu-se, assim, uma nova correlação de forças, proporcionando aos países considerados subdesenvolvidos um papel decisivo no desenho das novas estratégias da organização.

É nesse contexto que emerge o conceito de políticas nacionais de comunicação. E, quando emerge, o faz atrelado da crítica ao capitalismo, acompanhando a mudança que fora progressivamente ocorrendo na UNESCO no período. Órgão de deliberação no qual inexistia poder formal de veto, a organização passara a contar com uma maioria expressiva de países recém-filiados, com suas representações naturalmente anti-imperialistas e com governos tendendo a formas socialistas de organização, ou, então, formas capitalistas nãoalinhadas aos países centrais da América do Norte e Europa. Estes últimos, países até então hegemônicos na UNESCO, tinham imposto, desde os anos 50, a linha política liberal do livre-fluxo da informação, em sintonia com os princípios econômicos de livre-mercado.

\footnotetext{
“Agora, no entanto, naquele final de década de 60, era desenvolvida na Unesco uma linha política para a comunicação que previa, para o desenvolvimento da imprensa, do rádio e da televisão, dos satélites e outras novas tecnologias de comunicação, uma intervenção explícita dos Estado nacionais, direta e indireta, fosse pela exploração de meios estatais de comunicação, fosse por regulamentos e normas diversas que ajustassem os eventuais meios privados aos programas, objetivos e metas que compunham o planejamento governamental para toda a sociedade” (Ramos, 1992, p. 2829).
} 
A mudança inaugurou um novo momento no discurso da organização, que passa a reconhecer o caráter processual da comunicação: "apesar de permanecer com grande destaque, a informação, agora, é parte e não o todo” (Gomes, A., 2007).

Em 1969, o francês Jean D’Arcy registrou, em um trabalho intitulado Les Droits de L'homme à Communiquer (Os Direitos do Homem à Comunicar), a premência de um novo direito humano na Declaração Universal dos Direitos Humanos de 1948. Ele chamava atenção para a necessidade do reconhecimento do direito humano à comunicação, por entender que os princípios jurídicos da liberdade de expressão e do direito à informação até então constantes nos documentos da Organização das Nações Unidas (ONU), não contemplavam a amplitude das necessidades para a garantia da dignidade humana.

Os argumentos construídos por D’Arcy não chegaram a fundamentar de forma minuciosa novos conceitos de liberdade de opinião, expressão e informação, direitos consagrados na então normativa internacional dos Direitos Humanos, mas fomentaram debates sobre o tema, sobretudo em relação a ampliação dos marcos regulatórios nacionais, que, segundo o autor, não mais atendiam às demandas dos avanços da indústria da comunicação de massa.

Assim D’Arcy sintetizou a visão emergente sobre o campo da comunicação:

"Na época da Ágora e do Foro, na época da comunicação interpessoal direta, surge primeiro - conceito básico para todo o progresso humano e para toda civilização - a liberdade de opinião [...] O surgimento da imprensa, que foi o primeiro dos meios de expressão de massa, provocou, pela sua própria expansão e contra as prerrogativas de controles reais ou religiosas, o conceito correlato de liberdade de expressão [...] O século dezenove, que presenciou o extraordinário desenvolvimento da grande imprensa, caracterizou-se por lutas constantes em prol da liberdade [...] A chegada sucessiva de outros meios de comunicação de massas - cinema, rádio, televisão - da mesma forma que o abuso de todas as propagandas em véspera de guerra, demonstraram rapidamente a necessidade e a possibilidade de um direito mais preciso, porém mais extenso, a saber, o de 'procurar, receber e difundir as informações e idéias sem consideração de fronteiras [...] ou por qualquer procedimento’. Hoje em dia parece possível um novo passo adiante: o direito do homem à comunicação, derivado de 
nossas últimas vitórias sobre o tempo e o espaço, da mesma forma que da nossa mais clara percepção do fenômeno da comunicação [...] Atualmente, vemos que engloba todas as liberdades, mas que além disso traz, tanto para os indivíduos quanto para as sociedades, os conceitos de acesso, de participação, de corrente bilateral de informação, que são todas elas necessárias, como percebemos hoje, para o desenvolvimento harmonioso do homem e da humanidade" (Os direitos do homem à comunicar, documento n. 39 CIC - UNESCO, 1983, p. 290-291).

Importava agora identificar que implicações, positivas e/ou negativas, a desigualdade de condições, sobretudo técnicas, para produção e difusão dos bens simbólicos, aportariam à divisão eqüitativa das riquezas materiais:

O desequilíbrio das correntes de noticias e da informação entre os países industrializados e os países em desenvolvimento tinha passado [na década de 1960] a ser um tema importante nas reuniões internacionais e um dos aspectos do debate sobre os problemas políticos e econômicos fundamentais do mundo atual. Hoje em dia [no final da década de 1970], não há praticamente ninguém que negue a realidade desse desequilíbrio. Mas não existe um acordo geral sobre as aplicações concretas do conceito, e menos ainda sobre as soluções possíveis do problema e as políticas que conviria aplicar para resolvê-los. Por esse motivo, os conceitos de circulação e de corrente de sentido único, de equilíbrio e de desequilíbrio passaram a ser elementos do debate e do confrontação internacional. (UNESCO, 1983, p. 57-58)

Neste período, o discurso da UNESCO se revelava mais claramente definido, estruturado em sete pilares inter-relacionados: a cooperação à reivindicação de uma nova ordem econômica internacional; as aplicações concretas e definição do conceito de uma Nova Ordem Mundial da Informação e Comunicação (NOMIC); uma deontologia dos meios de comunicação social; o aprofundamento e redefinição do papel que desempenhavam os meios e os processos de comunicação nas sociedades contemporâneas; a proposta, definição e articulação da complementaridade entre cultura e comunicação; a formulação de políticas e planos de comunicação no âmbito nacional, regional e internacional; e a emergência da investigação sobre o direito à comunicação (Gomes, A., 2007, p. 90). 
Na $16^{\circ}$ reunião da Conferência Geral de 1970, os “[...] vários países em desenvolvimento solicitaram explicitamente, o que caberia qualificar de problemática da distribuição desigual dos meios de informação” (UNESCO, 1988, p. 81-82). A resposta, direta e precisa, veio no discurso da Declaração sobre os princípios vetores do emprego das transmissões por satélite, em 1972. A afirmação categórica de que “as freqüências radioelétricas são um recurso natural limitado pertencentes a todas as nações [...]” deixou claro que, para respeitar o direito de todas as pessoas “[...] a investigar e receber informações e opiniões, e a difundir-las, sem limitação de fronteiras [...]”, era necessário colocar em prática um sistema de cooperação, não de concorrência tecnológica ${ }^{72}$.

Embora ainda preponderante, a expressão "livre circulação da informação" foi vinculada a uma série de condicionamentos para sua efetivação, como o respeito à soberania dos países; a fixação de códigos deontológicos para estimularem nos “[...] profissionais de informação o sentido da responsabilidade que deve ir unido à vontade de respeitar em toda a medida possível a liberdade de informação” (UNESCO, 1972, p.72, tradução nossa); o respeito aos direitos humanos e as liberdades fundamentais; reconhecendo-se uma outra dimensão à comunicação mundial. À concepção do livre fluxo dos bens simbólicos atrelaram-se outros princípios e valores, como o respeito aos processos de cada país em relação às condições econômicas e à necessidade de um diálogo entre as culturas. Ao apelo à compreensão entre os povos figurou a premência de considerar os “direitos do público”.

Percebe-se, deste modo, um interesse mais acentuado na parte dos estudos e investigações em matéria de comunicação visando fomentar “[...] sua aplicação na formulação das políticas de comunicação e na elaboração de estratégias e planos nacionais a serviço do desenvolvimento [...]” (UNESCO, 1973, p.71, tradução nossa).

Esse discurso reforçou a defesa do Estado como promotor e efetivador dos direitos humanos, e o enfrentamento das questões que dificultavam o exercício pleno do direto à liberdade de expressão e informação baseada no fluxo livre e equilibrado, na democratização no uso dos meios de comunicação e no direito à comunicação ganhou força.

${ }^{72}$ Ata da Conferência Geral da UNESCO - 17ª reunião, Paris, 1972, 
As resoluções da $18^{a}$ Conferência Geral da organização marcaram o começo dos confrontos teóricos e políticos mais acirrados, especialmente no que se refere à entrada de novos conceitos e às idéias e propostas de uma nova ordem econômica internacional.

A partir de 1974, o conceito passou a fazer parte da agenda e do vocábulo internacional. Em 1976, com a constituição da NOMIC sob forte influência dos países não-alinhados, foi constituída uma comissão presidida pelo irlandês Sean Macbride ${ }^{73}$ que, quatro anos mais tarde, em 1980, publicou o relatório Um Mundo, Muitas Vozes (UNESCO, 1983), conhecido também como Relatório Macbride, que reforçou explicitamente a necessidade de reconhecimento do direito à comunicação como princípio jurídico, sendo este conjunto de textos até hoje a principal referência dos estudos que abordam a emergência do DHC.

A base crítica do relatório foi a intensa a disparidade entre o Norte (Países desenvolvidos) e o Sul (Países em desenvolvimento):

As disparidades são cada vez maiores e mais graves. Isto indica que existem outras necessidades que não são unicamente as de assistência: a eliminação das estruturas injustas e opressoras, a revisão da divisão atual do trabalho e o estabelecimento de uma nova ordem econômica mundial. A comunicação é um fiel reflexo das disparidades que caracterizam o mundo internacional e, por conseguinte, necessita de algumas mudanças que tenham esse mesmo alcance. Essas são as razões fundamentais que advogam em prol do estabelecimento de uma nova ordem mundial da comunicação (Ibidem, p. 302-303).

As reflexões, orientações e diretrizes colocadas para o reconhecimento e efetivação de um outro modelo de comunicação global - com um fluxo de informação e conhecimento horizontal, privilegiando o diálogo em detrimento do monólogo, não restritivo aos detentores das novas tecnologias - passaram a girar em torno da aposta em um novo

\footnotetext{
${ }^{73}$ Chamada Comissão Internacional para o Estudo dos Problemas da Comunicação, era integrada por: Elie Abel (EUA), Hubert Beuve-Méry (França), Eleke Ma Ekonzo (Zaire), Gabriel García Marquez (Colômbia), Sergei Losev (União Soviética), Mochtar Lubis (Indonésia), Mustapha Masmoudi (Tunísia), Michio Nagai (Japão), Fred Isaac Akporuano Omu (Nigéria), Bogdan Osolnik (Iugoslávia), Gamal ElOteifi (Egito), Johannes Pieter Pronk (Holanda), Juan Somavía (Chile), Boobli George Verghese (Índia), e Betty Zimmerman (Canadá).
} 
modelo de desenvolvimento social - que descentralizasse o poder e a riqueza, que buscasse a emancipação de todos os povos e suas respectivas culturas, e que priorizasse a radicalização da democracia.

Assim, não é exagero afirmar ser o relatório um contundente manifesto anticapitalista, que deixa explícito em suas páginas a impossibilidade de atingir um outro projeto de comunicação com o projeto político e econômico então vigente.

Por outro lado - e de forma complementar -, embora identificado com a utopia socialista, o projeto de uma "nova ordem para a comunicação e a informação" também refutava laços com os modelos autoritários e opressores da liberdade de expressão dos países bloco liderado pela União Soviética: a comunicação nem poderia estar somente nas mãos do mercado nem tampouco do Estado, mas fundamentalmente nas da sociedade civil. Em diversas passagens, o relatório chama atenção para o caráter da indústria da comunicação, onde comumente não existe separação entre quem produz, distribui e controla o processo, e registra a preocupação tanto com a mercantização da comunicação quanto com a estatização dos meios, tendo em vista o perigo que ambos trazem à democracia. A corrente de informação de sentido único, segundo o relatório, é um reflexo das estruturas políticas e econômicas dominantes do mundo, que fortalecem a situação de dependência dos países pobres em relação aos ricos (Ibidem, p. 243).

Em relação à inclusão da comunicação no rol de direitos humanos, o relatório é contundente:

Hoje em dia se considera que a comunicação é um aspecto dos direitos humanos. Mas esse direito é cada vez mais concebido como o direito de comunicar, passando-se por cima do direito de receber comunicação ou de ser informado. Acredita-se que a comunicação seja um processo bidirecional, cujos participantes - indivíduos ou coletivos - mantêm um diálogo democrático e equilibrado. Esta idéia de diálogo, contraposta a de monólogo, é a própria base de muitas das idéias atuais que levam ao reconhecimento de novos direitos humanos (Ibidem, p. 287). 
Em outro trecho relevante, assim foram sintetizados os direitos que devem ser considerados quando nos referimos ao direito à comunicação, assim como quais seriam as violações a estes direitos:

I. O direito de saber, isto é, a ser informado, e a procurar livremente qualquer informação que deseje obter, principalmente quando se refere à vida, ao trabalho, ou às decisões que é preciso adotar, tanto individualmente quanto como membro da comunidade. A negativa de comunicar uma informação e/ou a divulgação de uma informação falsa ou deformada constituem uma infração desse direito;

II. O direito do indivíduo de transmitir aos outros a verdade, tal como a concebe, sobre as suas condições de vida, as suas aspirações, as suas necessidades e as suas queixas. Infringi-se esse direito quando se reduz o indivíduo ao silêncio mediante a intimidação ou uma sanção, ou quando se nega a ele o acesso a um meio de comunicação;

III. O direito a discutir: a comunicação deve ser um processo aberto de resposta, reflexão e debate. Esse direito garante a livre aceitação das ações coletivas e permite ao indivíduo influir nas decisões que tomam os responsáveis (UNESCO, 1983, p.187, grifos nossos).

Os EUA, evidentemente, reagiram à orientação política tomada pela UNESCO. Enxergando no debate, com uma certa razão, a presença dominante de idéias marxistas, o presidente norte-americano, Ronald Reagan, liderou o movimento de esvaziamento da organização como foro privilegiado de debate e elaboração de propostas de mudanças nos cenários internacionais da comunicação. E o fez da maneira mais eficaz possível, começando por reduzir drasticamente os aportes financeiros com que os Estados Unidos e seus principais aliados sustentavam o orçamento da organização, até chegar ao ponto de retirar formalmente o seu país da UNESCO, no que seria acompanhado, em seguida, pela Grã-Bretanha e pelo Japão ${ }^{74}$. Assim, sufocado financeiramente, o debate das políticas nacionais de comunicação foi virtualmente varrido dos cenários acadêmicos e políticos, nos anos 80, pela onda neoliberal (Ramos, 1992, p. 31).

\footnotetext{
${ }^{74}$ Para saber mais sobre o posicionamento dos EUA em relação à NOMIC, ver artigo do jornalista e professor da Universidade de Columbia, Joseph Mehan, disponível em $<$ http://www.idsnet.org/Papers/Communications/JOSEPH_MEHAN.HTM>
} 
Nesse processo, é relevante notar que a principal acusação dos Estados Unidos à UNESCO era justamente a de que o órgão multilateral, ao levar à cabo reflexões daquela natureza, estava na prática a incentivar o controle governamental dos meios de comunicação e a supressão da liberdade de imprensa (CRIS, 2005) .

Nas décadas de 1980 e 90, assim, foram raras as investigações teóricas que se detiveram sobre o tema do direito à comunicação. Entre elas, é impossível não fazer menção à definição de José Salomão Amorim (1986), baseado em estudos sobre o relatório da UNESCO:

\begin{abstract}
"Estas circunstâncias fazem com que se passe a ver a comunicação na perspectiva de um direito e não apenas de liberdade, e na perspectiva de outros direitos fundamentais do cidadão, como o direito à educação, à saúde, à habitação e ao trabalho. A mudança está que a palavra direito implica em obrigações de a sociedade, através do Estado, oferecer as condições para que este direito seja atendido. O conceito de liberdade de expressão não tem como pressuposto essa obrigação, na medida em que permite ao Estado se situar numa posição passiva, deixando a tarefa de realizar a comunicação democrática entregue ao livre jogo das forças sociais” (Amorim, 1986, p. $52)$.
\end{abstract}

Algumas construções teóricas, como a de Aluisio Ferreira (1997) também buscaram demarcar a necessidade da consideração de um direito mais amplo do que o direito à informação:

Sobressai a evidência de que o direito à informação e o direito à comunicação são indissociáveis, mas inconfundíveis. [...] o direito à informação compreende as faculdades de colher e de receber informações, [...] Já o direito à comunicação, perante o qual o mesmo sujeito se comporta ativa e passivamente, compreende as faculdades de colher, receber e comunicar, porquanto comunicação pressupõe e implica compartilhamento de informações. [...] Desta forma, o direito à comunicação somente faz sentido na perspectiva do direito à informação [...] (1997, p.167-168, grifos do autor). 
A demanda pelo reconhecimento do direito à comunicação ressurge de forma mais incisiva a partir de 2001, com os preparativos para realização da Cúpula Mundial sobre a Sociedade da Informação realizada no âmbito da ONU em dezembro de 2003, que culminou com o surgimento de uma campanha civil internacional intitulada CRIS - Communications Rights in the Information Society, cujo capítulo brasileiro foi denominado Campanha Nacional pelo Direito à Comunicação e liderado por organizações de perfis distintos ${ }^{75}$.

Em função do debate crescente em torno Cúpula, o então secretário geral da ONU, Kofi Annan, declarou que "milhões de pessoas dos países mais pobres continuam excluídos do direito de comunicar, um direito cada vez mais percebido como um direito humano fundamental" (ONU, 2003, tradução nossa). Também nos debates em torno da Cúpula, um documento oficial da Comissão Européia observou que ela deveria "reforçar o direito à comunicação e o acesso à informação e ao conhecimento" (Comissão Européia, 2002, tradução nossa).

Desde então, o discurso sobre o direito à comunicação tem sido apropriado de forma progressiva por atores sociais que atuam em diversos campos dos direitos humanos, como a Educação, a Saúde, os direitos de igualdade de gênero e racial, o direito à terra, entre outros. Símbolo maior dessa apropriação social é o fato do direito à comunicação ter sido estabelecido como tema central do I Encontro Nacional de Direitos Humanos, realizado em agosto de 2005. A carta final do encontro assim resumiu o novo direito:

\footnotetext{
Após dois dias de Encontro, em que nós, militantes, defensoras e defensores de direitos humanos, parlamentares comprometidas(os) com as causas populares, servidoras e servidores públicos de instituições federais, estaduais e municipais, compartilhamos experiências e produzimos subsídios para a formulação de políticas públicas destinadas a consagrar o direito à comunicação como direito humano fundamental e de fazer avançar a implementação do conjunto de direitos humanos; [...] Declaramos que: 1 . A Comunicação é um direito humano que deve ser tratado no mesmo nível e grau de importância que os demais direitos humanos. $\mathbf{O}$ direito humano

${ }^{75}$ Como o Intervozes - Coletivo Brasil de Comunicação Social, a RITS - Rede de Informações para o Terceiro Setor e o braço nacional da AMARC - Associação Mundial de Rádios Comunitárias, que compuseram a sua coordenação.
} 
à comunicação incorpora a inalienável e fundamental liberdade de expressão e o direito à informação, ao acesso pleno e às condições de sua produção, e avança para compreender a garantia de diversidade $e$ pluralidade de meios e conteúdos, a garantia de acesso eqüitativo às tecnologias da informação e da comunicação, a socialização do conhecimento a partir de um regime equilibrado que expresse a diversidade cultural, racial e sexual; além da participação efetiva da sociedade na construção de políticas públicas, tais como conselhos de comunicação, conferências nacionais e regionais e locais. A importância do direito humano à comunicação está ligada ao papel da comunicação na construção de identidades, subjetividades e do imaginário da população, bem como na conformação das relações de poder (MNDH, 2005, grifos nossos).

Frente a essas e outras evidências, não há outra conclusão possível: a intensidade com a qual o termo é atualmente utilizado e foi incorporado por organizações de defesa dos direitos humanos aponta ser a demanda pelo reconhecimento do DHC irreversível.

Este direito pode ser compreendido como parte do mesmo movimento iniciado no final do século XIX, quando setores populares reivindicaram o reconhecimento de direitos econômicos e sociais, acrescentando às liberdades negativas conquistadas no passado a necessidade de condições mínimas de igualdade material (e não meramente formal). Enquanto alguns direitos que possuem essa perspectiva (os chamados direitos de segunda geração, ou direitos econômicos e sociais) foram sendo progressivamente reconhecidos - como os direitos ao trabalho, à educação e à saúde - a comunicação social, neste mesmo período, foi apropriada pelo capital e, em países como o Brasil, também pelas oligarquias locais/regionais, percorrendo caminho inverso aos outros campos objeto de direitos humanos: nos países em que havia sistemas púbicos de radiodifusão, estes passaram a ser substituídos ou enfrentados pelos sistemas comerciais; nos países onde havia empresas estatais de telecomunicações, estas foram privatizadas e entregues a empresas transnacionais; onde havia regras anti-concentração, as mesmas foram eliminadas.

O debate imposto pela NOMIC e posteriormente revigorado em razão da Cúpula Mundial sobre a Sociedade da Informação, portanto, pode ser considerado análogo ao já abordado 
por diversos autores estudiosos da Democracia e que consiste na diferenciação do sufrágio universal do sufrágio restrito, que, na prática, se refere ao debate sobre a extensão do sufrágio. A busca pela universalidade do sufrágio esteve baseada no princípio da igualdade inerente à condição humana. A busca empreendida pela superação da liberdade de expressão entendida exclusivamente como liberdade negativa consiste em estender tal liberdade para todos os indivíduos e grupos e, portanto, tornar igualmente possível o exercício dessa liberdade.

Sob essa perspectiva, o direito à comunicação deve ser observado como um prolongamento lógico do processo constante em direção à liberdade e à democracia: a exigência de circulação de dupla direção, de intercâmbio livre e de possibilidade de acesso e participação dão nova dimensão qualitativa às liberdades conquistadas sucessivamente no passado.

Com a inflexão do paradigma, busca-se ampliar o alcance jurídico da regulação das comunicações a partir do significado conceitual sintetizado por Paulo Freire, que busca na horizontalidade das relações comunicativas uma forma essencial de realização da dignidade humana.

Dessa forma, acredita-se que a construção histórica aqui apresentada aponta ser o DHC o direito à participação em condições de igualdade da esfera pública mediada pelas comunicações sociais e eletrônicas. Assim como os direitos sociais, econômicos e culturais significaram um avanço da liberdade rumo à igualdade, este mesmo movimento, embora tardio e com características específicas, também acabou por desaguar na reivindicação pelo reconhecimento do direito à comunicação. 


\section{2 - A EXPANSÃO DO DIREITO À COMUNICAÇÃO}

Como visto no capítulo anterior, a demanda pelo reconhecimento do direito humano à comunicação deriva essencialmente da necessidade de ampliar o escopo da liberdade de expressão e do direito à informação rumo ao direito dos indivíduos e grupos sociais de acesso e participação ativa na esfera pública. Tal determinação busca afirmar sobretudo o sentido da comunicação, seu ethos, ou, dito de outra forma, a sua utopia, sob a qual, a partir do momento em que a comunicação já não mais se refere somente às relações interpessoais e passa a ser um processo socialmente organizado por tecnologias e suportes, se constrói o paradigma do direito humano à comunicação.

Nessa perspectiva, à liberdade negativa clássica devem ser acrescentadas, para a efetivação da dignidade humana no campo das comunicações, prestações positivas do Estado que objetivem garantir condições efetivas para o exercício dos direitos e liberdades na esfera pública. Assim, se a busca pelo respeito à liberdade de expressão guiou-se historicamente pela negação da intervenção do Estado no setor da comunicação social, o direito à comunicação determina a necessidade de um Estado, que atue para evitar privilégios e garantir, em diferentes frentes, o direito à participação na esfera pública. Como implicação prática, ao Estado se impõe o dever de garantir os meios técnicos e materiais - além do conhecimento, evidentemente - para que indivíduos e grupos sociais tenham condições de produzir e veicular conteúdos que julguem pertinentes, e que estes conteúdos efetivamente circulem na esfera pública.

Esta ampliação, como já dito, guarda relação com a busca pela positivação dos direitos econômicos e sociais, na medida em que busca determinar, para além da igualdade formal, também a igualdade material entre indivíduos e grupos sociais no acesso ao espaço público midiático.

Esta igualdade é condição indispensável para a compreensão do DHC: reconhecê-la como imprescindível significa definir que a democracia só se realiza na medida em que a circulação de informação se faz baseada em critérios e regras que busquem garantir a 
equidade de condições para produzir e difundir conteúdos na esfera pública. Regras e normas que impeçam a formação de monopólios e oligopólios cruzados, verticais e horizontais, assim como o direito de antena (como consagrado nas constituições portuguesa e espanhola) são, nesse sentido, embora imprescindíveis, somente parte do dever estatal.

Há profunda relação desta tese com a noção de comunicação defendida por Paulo Freire. Como exposto no capítulo inicial desta dissertação, Freire define comunicação como diálogo. Diálogo, por sua vez, para realizar-se, tem como pressuposto uma condição de igualdade entre os partícipes. Situações onde imperam desigualdades, deste modo, impedem a plena realização do direito à comunicação. Assim, embora alguns autores qualifiquem este pressuposto do DHC como o "direito de acesso” ao espaço público, julgase que a melhor forma de definir este elemento do direito à comunicação seja qualificá-lo como o direito à participação do espaço público em condições de igualdade formal e material. É o conceito de comunicação exposto por Freire que permite afirmar esta dimensão do DHC, que tem como decorrência, no plano teórico, a garantia de máxima pluralidade e a diversidade na comunicação mediada por tecnologias ${ }^{76}$.

Além da necessidade de prestações positivas do Estado para garantir uma igualdade mínima de acesso à esfera pública, contudo, acredito existirem outros elementos que simultaneamente justificam a emergência do DHC e o definem de forma mais precisa. A força com que as questões relacionadas à área penetram nas formulações e ações políticas de organizações e entidades civis, assim como nas investigações de cunho acadêmico (muitas vezes sob a demanda dessas mesmas organizações), aponta para a ampliação significativa de seu escopo, alargando-o e expandido-o em diversas direções.

Desde o surgimento do conceito na década de 1970, o mais relevante esforço para se estabelecer os direitos e liberdades abrangidos pelo DHC foi realizado no âmbito do Global Governance Project, projeto da Campanha Cris, entre os anos de 2004 e 2005.

\footnotetext{
${ }^{76}$ Note-se que "comunicação mediada por tecnologias” se aplica a um universo mais amplo do que, por exemplo, “comunicação de massa”, que se refere somente aos meios de comunicação desenvolvidos no século $\mathrm{XX}$, como o rádio, a televisão ou os grandes jornais impressos.
} 
Durante um ano, pesquisadores vinculados a organizações da sociedade civil de diversos países (Brasil, Colômbia, Quênia, Filipinas, Itália, Canadá, Irlanda, Estados Unidos e Reino Unido $^{77}$, se debruçaram sobre a tarefa de criação de um quadro de referência para a avaliação do estágio de efetivação do direito à comunicação nos diferentes países.

O escopo de incidência do direito à comunicação foi dividido em quatro pilares: (A) esfera pública; (b) uso do conhecimento e domínio público; (C) liberdades civis na sociedade da informação e; (D) acesso eqüitativo a Tecnologias de Informação e Comunicação(TICs).

O escopo completo dos pilares, com os sub-tópicos de cada um dos indicadores, consta dos anexos desta dissertação.

Embora estes indicadores possam ser considerados razoavelmente completos, julga-se relevante avançar nas características complementares que compõe, no plano teórico, as bases e alicerces atuais do direito à comunicação.

\section{1 - Direito guarda-chuva}

O direito à comunicação é um direito guarda-chuva, abrigo de uma série de direitos e liberdades que, embora tenham relação com a comunicação, foram historicamente considerados desconexos, sem unidade jurídica que dê sentido à relação de uns com os outros. O DHC é, nessa perspectiva, a busca por um olhar amplo sobre o conjunto das necessidades para a garantia da dignidade no campo da comunicação, suas transversalidades e interfaces. No DHC se entrelaçam direitos de grupos sociais específicos (de gênero, raça e etnia, orientação sexual), direitos da infância e da terceira (melhor) idade, direitos ligados ao campo cultural, direitos civis e políticos, direitos sociais e econômicos. São direitos negativos e positivos, que requerem atitudes diversas dos agentes públicos e

\footnotetext{
${ }^{77}$ No Brasil, a organização responsável pelo estudo foi o Intervozes - Coletivo Brasil de Comunicação Social, Este autor participou da pesquisa realizada em âmbito nacional, coordenada em conjunto com os pesquisadores João Brant e Márcio Kameoka. A pesquisa completa pode ser acessada em $<$ www.intervozes.org.br> ou em <www.crisinfo.org>.
} 
que buscam garantir a dignidade humana em diferentes dimensões. A sua unidade nasce da relação com a comunicação.

Dessa forma, embora se reconheça a indissociabilidade e a interdependência entre todos os direitos humanos - características consagradas no plano jurídico internacional, especialmente após a Conferência de Viena de 1993 -, no direito à comunicação essa característica revela toda a sua força. A apropriação do conceito por organizações da sociedade civil cuja origem de atuação é diversa (ou seja, não necessariamente ligada aos campo da comunicação) é revelador da natureza transversal do DHC, assim como é a presença de resoluções sobre o campo comunicação em Conferências setoriais que incidem sobre diversos temas - como a Saúde, Educação, Meio Ambiente, Segurança Pública, Criança e Adolescente, entre tantos outros. Em todas elas, a comunicação se faz presente.

\section{2 - Localização e titularidade}

O direito à comunicação deve ser considerado um direito público subjetivo ${ }^{78}$, na medida em que imputa aos Poderes Públicos deveres de comportamentos negativos ou positivos, sendo os segundos, como já dito, realizados por meio de políticas regulatórias e políticas públicas. Tal característica, contudo, não elimina, no âmbito do DHC, nuances de direito privado, em função da potencial violação do direito por particulares, como pode ocorrer, por exemplo, no caso de violações à privacidade.

\footnotetext{
${ }^{78}$ Por direito subjetivo, deve-se entender os direitos nos quais há um vínculo de pertinência de um bem da vida a alguém, que algo lhe pertence como próprio. De acordo com Comparato (2002), devem ser reconhecidas duas espécies de direitos subjetivos: uma em sentido técnico (direito subjetivo stricto sensu) e o poder jurídico. A primeira corresponde a uma situação jurídica em que o titular tem o direito a um comportamento positivo ou negativo por parte do sujeito passivo que, por sua vez, tem um dever em relação ao titular do direito. Nesta relação jurídica, os sujeitos passivos podem ser tanto pessoas particulares quanto os Poderes Públicos, sendo os direitos, neste caso, direitos públicos subjetivos. Já o poder jurídico não tem por objeto um comportamento alheio, mas exerce-se sobre a figura jurídica de outrem, como é o caso do direito de votar, do direito de acesso à função pública, o direito à autodeterminação política dos povos e o direito a mudar de nacionalidade. Já a pretensão é o modo, judicial ou extra-judicial, reconhecido no ordenamento jurídico, para garantir o respeito ao direito subjetivo. É por meio do exercício da pretensão (da qual a ação judicial é somente uma das formas) que se exige do sujeito passivo a satisfação do direito. Tem-se, então, que em certos casos a ausência da pretensão não significa a inexistência de direitos subjetivos, sendo a pretensão, portanto, somente acessória em relação ao direito.
} 
Por ser abrigo de diferentes dimensões da dignidade humana, o DHC, por conseqüência, não é passível de qualificação única, capaz de determinar sua titularidade ou localizálo em uma única geração de direitos. O direito à comunicação, por certo, está intimamente ligado ao exercício dos direitos civis e políticos, assim como a fruição dos direitos econômicos, sociais e culturais. O DHC é ele próprio a síntese de diferentes direitos e liberdades historicamente reconhecidos, como a liberdade de pensamento e opinião, reunião, expressão, o direito à informação, à cultura, à privacidade, à honra e uma série de outros direitos que possuem relação com campo da comunicação. Por isso, parece incorreto definir ser o direito à comunicação, como fazem alguns autores, exclusivamente como um “direito da humanidade” (de terceira ou quarta geração, a depender da perspectiva que moveu a classificação dos direitos). Isso porque, embora o tempo histórico do surgimento da demanda por seu reconhecimento coincida com estes “novos” direitos e esteja também atrelado ao desenvolvimento das novas tecnologias, o DHC é justamente o ponto de encontro de diferentes direitos e liberdades, alguns consagrados como parte do aparato jurídico dos direitos humanos há mais de duzentos anos.

É importante notar que no DHC cabem tanto direitos-meio como direitos-fim, sendo sua posição alterada de acordo com a perspectiva que se pretende buscar ${ }^{79}$. A radicalização da democratização dos meios de comunicação, com o respeito à participação dos indivíduos e grupos sociais na esfera pública, por exemplo, é um direito humano destes indivíduos e grupos, se constituindo, assim, como um direito-fim. Por outro lado, este mesmo ambiente democrático é fundamental para que as sociedades tenham condições de discutir e encontrar os melhores caminhos para a solução de questões importantes à garantia de outros direitos humanos. Nesse contexto, se constitui em um direito-meio, por ser um instrumento para a realização de outros direitos. É correto afirmar, no entanto, que a obstrução ou não realização de uma dessas perspectivas acaba por impactar na outra.

Como conseqüência dessa multiplicidade de aspectos, o DHC também não comporta definição de titularidade única. Em cada uma das perspectivas, se apresenta tanto como

\footnotetext{
${ }^{79}$ Como explica Comparato (2003), é possível qualificar estes dois “tipos" de direito. O direito à propriedade, por exemplo, é um direito-meio para a garantia do direito à vida, assim como o direito ao trabalho o é em relação ao direito à auto-subsistência econômica.
} 
um direito individual quanto como um direito coletivo ou difuso, muitas vezes combinando duas ou mesmo as três perspectivas. O caso do direito à proteção contra conteúdos abusivos e violadores de outros direitos humanos é um exemplo desta combinação: no dever do Estado em garantir a restrição dos discursos de ódio e preconceituosos contra diversos grupos sociais reside tanto um direito do indivíduo (de não receber mensagens ofensivas de qualquer natureza), quanto dos grupos ofendidos (de não ser objeto de preconceito, especialmente nos meios de comunicação) e da sociedade em geral (de promover a dignidade e os direitos humanos de forma progressiva, para o qual um ambiente desprovido deste tipo de manifestação é imprescindível). Em uma série de casos específicos, é claro, a titularidade do DHC é determinável de forma simples, como o direito do autor em ter suas obras reconhecidas, ou o direito à privacidade no uso das novas tecnologias (direitos individuais clássicos), mas sua integralidade certamente implica em reconhecer essa múltipla titularidade ${ }^{80}$.

\section{3 - Dimensão cultural}

\section{O direito à comunicação reforça de forma vigorosa a centralidade dos bens culturais} como parte da informação que circula na esfera pública. Tradicionalmente, a liberdade de expressão e, de forma ainda mais forte, o direito à informação, são princípios jurídicos aplicados ao conteúdo jornalístico, ou seja, à informação noticiosa. O direito à comunicação avança ao valorizar os conteúdos e bens culturais e artísticos como fundamentais à garantia da dignidade humana no campo das comunicações, devendo estes, por isso, também contarem com condições de serem produzidos e difundidos em um ambiente equânime. O Plano Nacional de Cultura (2008) é inequívoco ao apontar esta

\footnotetext{
${ }^{80}$ Esta mesma questão, embora de modo menos flagrante, se coloca a um dos elementos do DHC, a liberdade de expressão: em geral, não há dúvida de que a liberdade de expressão é um direito fundamental pertencente à categoria “direitos individuais”. Não obstante, algumas teorias, como a defendida por Cláudio Luiz Bueno de Godoy, sugerem que a liberdade de expressão também poderia ter a natureza jurídica de direito coletivo, uma vez que visa à construção de uma comunicação social pública. A liberdade de expressão, sendo considerada fundamental para a liberdade de informação (entendida como o direito de informar e ser informado), atende a um interesse coletivo (2001, p. 62).
} 
relação, impondo uma série de diretrizes à regulação dos meios de comunicação de massa para a garantia do direito à cultura ${ }^{81}$.

Não é estranho, pois, que muitos autores como Chauí (2006), Ortiz (1994) e V. Lima (1981) proponham a dissolução das fronteiras teóricas entre a comunicação e a cultura. Embora a discussão seja complexa, é certo que embora existam elementos em um e em outro conceito que dificilmente transbordem idéia de “cultura” ou “comunicação”, a realidade prática é inequívoca ao afirmar que parte substancial dos bens culturais, hoje e cada vez mais, é produzida e difundida pelos diversos meios de comunicação.

\section{4 - Equilíbrio entre direitos fundamentais}

\section{O direito à comunicação é resultado de equilíbrios entre outros direitos fundamentais,} em busca do que Robert Alexy (2008, p. 90) denominou ser um "mandamento de otimização”, que tende a variar segundo condições fáticas e jurídicas específicas. Um destes equilíbrios ocorre entre o direito à liberdade de expressão (como prestação negativa, ou seja, como obrigação de não interferência do Estado e de particulares) e a proteção da sociedade contra conteúdos lesivos e abusivos. Para atingir este equilíbrio, geralmente tratado sob a perspectiva da colisão entre direitos fundamentais, é necessário limitar certos tipos de expressão - como os discursos de ódio, as manifestações de preconceito, os conteúdos lesivos à infância e à saúde pública (como a publicidade de cigarros, por

81 Estão entre as diretrizes do Plano que se aplicam diretamente à comunicação mediada por tecnologias: 1.9 - Garantir as condições materiais e socioambientais, além das bases institucionais e técnicas, necessárias à produção, reprodução e transmissão de bens culturais de natureza imaterial. 2.2 - Incentivar a instalação e a manutenção de equipamentos e estabelecimentos culturais multiuso privados, especialmente em áreas do país ainda desatendidas e com problemas de sustentação econômica. 2.3 - Institucionalizar e ampliar a rede de centros culturais geridos por grupos culturais e artistas com capacidade para o desenvolvimento de atividades diversificadas, como a preservação e a valorização da memória, a inclusão digital e a produção e a difusão audiovisual. 2.8 - Fomentar a aquisição de computadores, programas e serviços de navegação para uso artístico e cultural, reservando atendimento especial para grupos detentores de saberes e práticas tradicionais e populares. 2.9 - Fomentar o desenvolvimento de "softwares” livres e públicos para a produção, a difusão e a gestão da cultura. 3.7 - Apoiar a elaboração de uma política pública de acesso veloz e gratuito à internet em todos os municípios brasileiros, de modo a garantir que as comunidades indígenas, afro-brasileiras, rurais e de áreas urbanas marginalizadas tenham acesso às tecnologias de comunicação e informação. 3.8 - Instituir programas em parceria com a iniciativa privada e organizações civis para a manutenção de rede de equipamentos digitais de acesso público em espaços como telecentros, lan-houses, bibliotecas multimídias, escolas, museus e centros culturais, entre outros. 
exemplo) - e garantir o pleno direito de resposta aos indivíduos e aos grupos sociais lesados $^{82}$.

Outro equilíbrio necessário no campo da comunicação ocorre entre o direito de autor em ter sua autoria reconhecida (direito moral) e explorar comercialmente sua obra (direito material) e o direito dos indivíduos e da sociedade em terem acesso à informação e aos bens culturais e educacionais, ou, como afirmam autores como Lessig (2005), terem "acesso ao conhecimento”. A medida certa entre a garantia dos autores e criadores em serem remunerados por suas obras e o acesso dos indivíduos ao conhecimento produzido - que acaba ampliar os conteúdos em domínio público - tem como resultado uma mediação que se traduz no respeito ao direito à comunicação.

$O$ vetor de equilíbrio aplicável aos casos concretos - o que certamente não é a regra neste início de século - traduz o respeito à dignidade humana e, portanto, ao direito humano à comunicação.

\section{5 - Educação e autonomia em relação aos meios de comunicação}

O direito à comunicação avança em relação à liberdade de expressão e ao direito à informação ao abranger o direito à autonomia e independência em relação aos meios de comunicação. Isso significa o direito de conhecer o modo de produção da informação mediada por tecnologias, para que os conteúdos recebidos sejam apropriados pelos indivíduos criticamente. Nessa perspectiva, ausência de um instrumental mínimo para a leitura autônoma dos meios de comunicação e de seus conteúdos é uma grave violação ao DHC, na medida em que esta condição é imprescindível para a garantia de indivíduos efetivamente livres.

\footnotetext{
${ }^{82}$ Para saber mais sobre a colisão de direitos fundamentais no campo da comunicação ver Joana Zylberstajn: Regulação de mídia e colisão entre direitos fundamentais, 2008, FD/USP.
} 
No plano político, essas demandas se traduzem há mais de quatro décadas em iniciativas dispersas - nacional e internacionalmente - conhecidas, entre outros termos, por "leitura crítica da mídia”, “alfabetização para os meios” e, na literatura anglo-saxã, “media literacy”.

Nesta característica, o DHC revela sua interface com o direito à educação, uma vez que a alfabetização (o domínio da linguagem escrita) é condição número um ao exercício do direito à comunicação. A relação, com a educação vai além: não só a educação deve estar à favor da comunicação autônoma, mas a comunicação deve participar da necessária tarefa de construção de uma Educação para os Direitos Humanos.

Na outra ponta, para a efetiva participação equânime na esfera pública, é preciso que os indivíduos e grupos sociais possuam o conhecimento necessário (certos conhecimentos técnicos, inclusive) para que tenham condições de produzir conteúdos, uma vez que as barreiras para a efetiva difusão de informação se encontram não somente no acesso aos meios materiais, mas também no acesso ao conhecimento sobre o processo de produção.

\section{6 - Participação e controle social}

Embora seja possível reconhecer esta característica em uma leitura mais ampla dos conceitos de liberdade de expressão e direito à informação, o direito à comunicação se move inequivocamente rumo ao direito à participação nos processos de regulação $e$ elaboração de políticas públicas e diretrizes regulatórias. Esta imposição, como afirma Boaventura de Sousa Santos (2002), é um dos fundamentos da utopia democrática contemporânea, sendo, por isso, progressivamente consagrada no âmbito dos direitos sociais, inclusive no Brasil. Fato é que, quando se impõe necessidade de formulação e implementação de políticas públicas, a importância da participação da sociedade especialmente por meio da sociedade civil - deixa de ser periférica e se tornar central.

A ausência histórica de mecanismos de incidência da sociedade sobre as comunicações, como visto nos capítulos anteriores, contribuiu decisivamente para a apropriação da esfera pública pelos detentores dos meios de produção e difusão de informação. A única forma de 
evitar a captura dos órgãos de regulação pelos detentores de poder de mercado é radicalizar a participação da sociedade civil nos processos de regulação - na formulação, deliberação e fiscalização (Salomão Filho, 2002) -, que passa, por isso, a se constituir como parte imprescindível à realização do DHC.

\section{7 - Comunicação não-comercial}

A construção histórica da compreensão acerca da liberdade de expressão e do direito à comunicação permitem levar à errônea conclusão de que o respeito a ambos estes direitos fundamentais pode se realizar em um ambiente dominado por meios privados e comerciais de comunicação. O reconhecimento do direito à comunicação, inversamente, determina ser impossível a realização da dignidade humana em um ambiente onde a circulação de informação é dominada pela busca do lucro, se opondo à idéia da informação e da cultura como mercadorias, como meros objetos de consumo. Nessa perspectiva, o DHC confere a reserva - se não total, pelo menos substancial - de meios, instrumentos e fluxos baseados no interesse público, protegidos contra as determinações comerciais de grandes corporações, sejam elas nacionais ou internacionais ${ }^{83}$.

O reconhecimento do DHC, dessa forma, impõe considerar que empresas privadas, embora possam eventualmente - caso bem reguladas e fiscalizadas -, contribuir para a efetivação do direito, não são capazes de garanti-lo em sua integralidade. Na radiodifusão, por exemplo, esta consideração tem como resultado a perspectiva da prioridade aos sistemas e emissoras sem fins lucrativos, autônomas em relação ao mercado (e também ao governo). Nas telecomunicações, a mesma lógica impõe a consideração da necessidade mínima de que a oferta dos serviços seja fortemente regulada pelo Estado e tratados sob a lógica dos serviços públicos essenciais ${ }^{84}$.

\footnotetext{
${ }^{83}$ Comparato (2000) reconheceu essa premissa ao propor a exclusão das outorgas de televisão a exploradores com finalidades lucrativas. "Para que o povo possa ver assegurado o seu direito fundamental à informação (CF, artigo 5, XIV), (...) é preciso vedar a organização dos veículos de comunicação sob a forma de empresa capitalista, o que significa proibir a utilização de sociedades mercantis, pois em todas elas o poder de controle pertence, em princípio, aos detentores do capital” (2000, p. 198).

${ }^{84}$ Celso Antônio Bandeira de Mello (2000) define serviço público como "toda atividade de oferecimento de utilidade ou comodidade material fruível diretamente pelos administrados, prestado pelo Estado ou por quem lhe faça as vezes, sob um regime de Direito Público - portanto, consagrador de prerrogativas de supremacia e
} 


\section{8 - Proteção e direito de resposta}

O direito à comunicação incorpora de forma vigorosa a necessidade de proteção da sociedade, dos indivíduos e de grupos sociais específicos contra conteúdos indevidos e indesejados. Grupos vulneráveis - em especial as crianças e adolescentes - têm o direito a não serem expostos a conteúdos potencialmente lesivos à sua formação e desenvolvimento. Restrições à publicidade destinada ao público infantil e aos conteúdos de cunho adulto são as demandas regulatórias que traduzem esta característica do DHC. Nota-se, neste como em outros casos, que o fato deste direito ser também tratado no âmbito dos Direitos das Crianças e Adolescentes, não o retira do escopo do direito à comunicação, uma vez que a interface com outros direitos humanos é justamente uma de suas características centrais.

Segmentos específicos historicamente marginalizados ou oprimidos devem ter na esfera pública um ambiente que favoreça a superação das desigualdades, não a perpetuação ou radicalização das mesmas. Por isso, os abusos à liberdade de expressão que ofendam a dignidade humana devem ser fortemente combatidos - sem que isso incorra em censuras prévias, evidentemente - e o incentivo ao conteúdo promotor dos direitos humanos deve estar entre as prioridades do Estado.

A proteção ao indivíduo e a grupos sociais específicos passa necessariamente por mecanismos eficazes de reparação em caso de atentados contra à honra e ao uso indevido de meios de comunicação, especialmente nos serviços regulados como é o caso da radiodifusão. É este o caso do direito de resposta - individual ou coletivo, uma vez que não só a pessoa singular a potencial vítima de abusos, mas também o são segmentos específicos ou mesmo toda a sociedade (Suiama, 2002; Comparato, 2001).

Tem razão Daniel Sarmento (2006) quando pondera, porém, que a categoria do hate speech não deve ser banalizada, especialmente para fins de repressão estatal: "Não há espaço para

de restrições especiais -, instituído pelo Estado em favor de interesses que houver definido como próprios no sistema normativo”. 
que o intérprete se engaje em abstrusas desconstruções dos atos expressivos, visando encontrar preconceitos e mensagens discriminatórias ocultas, para assim fundamentar limitações às liberdades comunicativas. Só as manifestações explícitas de ódio, intolerância e preconceito contam para este fim. As demais podem e devem ser desmontadas e combatidas, mas através da crítica pública e não da repressão juridicamente institucionalizada" (2006, p. 261).

\section{9 - Direito de acesso às novas tecnologias e gestão das redes}

O DHC possui em seu "DNA" a consideração dos indivíduos e dos grupos sociais em sua relação com mundo, o que impõe, para sua garantia, demandas em progressiva expansão, como resultado do avanço contínuo e permanente da presença dos meios de comunicação na vida dos indivíduos. Nessa perspectiva, mais do que a liberdade de expressão e o direito à informação, o DHC considera as múltiplas implicações que o desenvolvimento tecnológico criou e continua a criar. Por isso, determina como fundamental para o respeito à dignidade humana a universalização do acesso a determinadas tecnologias e serviços, de forma a manter as condições de participação na esfera pública minimamente equânimes, evitando a criação de novos desníveis e privilégios, fatores decisivos na violação ao direito à comunicação.

A necessidade de universalizar (de forma minimamente equânime) o acesso à Internet banda larga, por exemplo, não é imposta por determinantes empíricos ou por dados estatisticamente aferíveis, embora seja possível utilizá-los para o mesmo propósito. Tal imposição emana prioritariamente de um imperativo ético, baseado na observação, de um lado, da importância que esta nova forma de relacionamento com o mundo adquire para os diferentes aspectos da vida cultural, social e econômica, sendo sua utilização uma ferramenta diária para diferentes tarefas ou funções, do lazer ao trabalho; e de outro, da certeza de que a não inclusão digital de cidadãos neste novo ambiente reproduzirá ou aumentará a já inaceitável desigualdade sócio-econômica existente no Brasil. 
Não é preciso esforço demasiado para aferir as diferenças de oportunidades que possuem hoje jovens com e sem acesso à Internet. Tal certeza não se aplica somente às possibilidades de ingresso no mercado de trabalho, mas também à fruição dos processos comunicativos nos quais se desenvolve habilidades e se adquire conhecimentos. Ao conjunto da população não se pode considerar de menor importância o acesso aos serviços de e-gov e aos serviços bancários já disponíveis, à troca de mensagens instantâneas ou por e-mail, entre tantos outros exemplos que poderiam ser utilizados para demonstrar que o acesso à Internet, hoje, como extensão do próprio ato de comunicar, deve ser considerado um instrumento prioritário para a garantia dos direitos humanos ligados ao campo da comunicação. Por isso, ao se afirmar a necessidade de universalizar a banda larga, quer se apontar, acima de tudo, para o país - ou o mundo - que se quer construir ${ }^{85}$.

Decorre deste imperativo a necessidade de observar a gestão das redes pelas quais trafegam os fluxos de conteúdos digitais - notoriamente a Internet -, uma vez que esta pode favorecer ou criar embaraços à fruição do DHC. A própria administração dos nomes e números IPs são imprescindíveis à manutenção da arquitetura livre das redes digitais. Uma gestão transparente, simultaneamente global e democrática (inversamente à situação atual) é pré-condição para o uso livre e equânime da Internet.

Com o crescimento do uso da Internet, uma das necessidades básicas (e conseqüentemente um direito da cidadania) mais importantes passa a ser a neutralidade de redes. As operadoras de telecomunicações que fornecem ao consumidor o acesso à Internet conseguem determinar em tempo real o perfil da informação que trafega em sua infraestrutura. Em alguns países (como notoriamente na China), tal prática tem como objetivo a censura da rede por parte do Estado. No Brasil e em outros países, contudo, as razões para o uso desses dispositivos têm justificativa comercial, pois estes permitem às operadoras degradarem a qualidade de determinados serviços ou funcionalidades, tornando inviável a

\footnotetext{
${ }^{85}$ A este imperativo ético, soma-se o fato do acesso à banda larga ser, pela própria essência do processo de convergência, a porta de entrada para todos os demais serviços de comunicações, permitindo o acesso a vídeos, textos e, especialmente, a serviços de voz, que podem ser prestados inclusive a partir de um número telefônico “comum”. Na hipótese de cada cidadão só ter acesso a um único serviço de telecomunicações, certamente dever-se-ia determinar ser este o acesso à Internet banda larga, na medida em que este suporta também o acesso aos serviços de voz e a conteúdos audiovisuais.
} 
sua plena utilização. Por isso, o acesso a conteúdos e aplicações na Internet deve ser, além de universal, e não-discriminatório, e os operadores de redes e de serviços de Internet devem garantir que os pacotes de informações transitem de forma isonômica nas redes, sem sofrer qualquer tipo de discriminação (Rodrigues, 2009).

Outra questão vinculada à gestão das redes digitais que compõe o escopo do DHC é o direito à privacidade. Com o avanço das técnicas de armazenamento e transmissão de dados, as possibilidades de violação da privacidade são maiores, criando um ambiente onde o usuário dos serviços de telecomunicações é colocado sob risco permanente de violação de seus direitos fundamentais. Mas não é apenas a vigilância por parte de governos que ameaça a privacidade do usuário de Internet. No mundo todo, empresas monitoram, armazenam e comercializam dados pessoais de usuários com o objetivo de monetizar suas práticas. O direito à comunicação inclui em seu guarda-chuva, a garantia de que os cidadãos e cidadãs tenham a prerrogativa unilateral de determinar quando, como, por quanto tempo, sob que circunstâncias e para que fins seus dados pessoais poderão ser armazenados, processados, divulgados, agregados ou combinados a outros dados, devendo ser o acesso a dados pessoais de cidadãos permitido somente mediante determinação judicial. 


\section{3 - EM BUSCA DA UTOPIA}

Embora o caminho percorrido até aqui permita considerar irreversível a emergência do direito à comunicação, a necessidade de reconhecimento formal, com sua positivação no plano jurídico, não é estratégia pacífica, consensual. Tais diferenças de entendimento existem desde os tempos de elaboração do Relatório Macbride. Desmond Fisher (1982), em busca de uma síntese dos debates que resultaram na elaboração dos relatórios finais, descreve as seguintes conclusões sobre os pontos de vista dos pesquisadores envolvidos em sua elaboração:

1. O conceito de um direito humano de comunicar é válido. Não há desacordo quanto à existência desse direito: as únicas opiniões divergentes são sobre se o fato de defini-lo como tal o vulgarizaria. Parece haver um acordo geral quanto ao fato de que o esforço para se concordar numa definição do direito e de abrigá-lo no direito nacional e internacional deve continuar.

2. Há desacordo quanto ao objeto do direito. Alguns o vêem como um direito pertencente ao indivíduo e somente subseqüente e secundariamente à sociedade; outros vêem a sociedade como a localização básica deste direito, com o Estado incumbido de restringir o direito no interesse público. Algumas pessoas favorecem um acomodamento que faria sujeito do direito o indivíduo na sociedade ou o gênero humano como um todo.

3. Há desacordo, também, sobre o conteúdo do direito. Querem alguns que a definição inclua todos os direitos e todas as liberdades associadas ao direito de comunicar, as limitações e restrições no exercício dessas liberdades e declarações sobre a partilha dos recursos de comunicação, os usos adequados da comunicação, os propósitos sociais da informação e questões similares. Outros sentem que a definição do direito de comunicar deveria ser uma simples afirmação do direito humano e que outras declarações sobre liberdades e obrigações de comunicação, sobre as circunstâncias em que podem legitimamente ser restringidos e sobre uma partilha mais justa dos recursos de comunicação, etc., deveriam ser deixadas para um foro diferente (e inferior).

4. Existe incerteza sobre como proceder com os estudos do conceito. Consideram alguns que não se deveria fazer nenhuma tentativa de impedir o debate e que se deveriam encorajar estudos ulteriores. Acreditam outros que chegou a hora de coordenar as diferentes tendências do debate e de se chegar a um acordo quanto a uma definição (Fisher, 1982, p. 97-98). 
Tais divergências não foram dirimidas nos vinte anos posteriores, sendo novamente evidenciadas durante a Cúpula Mundial sobre a Sociedade da Informação, em 2002, com a formulação de três abordagens distintas (Brittos, 2005).

A primeira, de caráter positivista, acredita que o direito à comunicação deve ser reconhecido como lei internacional e acrescentado à Declaração Universal dos Direitos Humanos. Dessa forma, a consecução de ações e iniciativas necessárias à garantia da dignidade humana no campo da comunicação transpareceriam de forma explícita, facilitando a sua aplicação no âmbito da formulação e implementação de políticas públicas, assim como sua exigência em juízo. Esta é a abordagem proposta, entre outros, por Cees Hamelink (2005):

As leis existentes de Direitos Humanos, asseguradas pelo artigo 19 da DUDH15 e artigo 19 da Convenção (sic) Internacional sobre Direitos Civis e Políticos, cobrem o direito fundamental à liberdade de opinião e de expressão. Isto é, indubitavelmente, uma base essencial para o processo de diálogo entre as pessoas, mas não se constitui como tráfego de mão dupla. É a liberdade de expressão do mendigo que fala em uma esquina, e a quem ninguém tem que ouvir, e que pode não estar se comunicando com ninguém. $\mathrm{O}$ artigo também se refere à liberdade de ter opiniões: isto se refere às opiniões dentro da cabeça das pessoas, que podem servir para a comunicação consigo mesmo, mas não necessariamente traz uma obrigatoriedade de comunicação com outros. Menciona o direito de buscar informações e idéias: dispõe para o processo de consultar e reunir notícias, por exemplo, o que é diferente de comunicar. Também há o direito a receber informação e idéias, o que é também, em princípio, um processo de mão única: o fato de que eu possa receber quaisquer informações ou idéias que eu queira não implica que eu esteja envolvido em um processo comunicacional. Finalmente, há o direito a disseminar informações ou idéias: isso se refere à disseminação/alocução que vai além da liberdade de expressão, mas os dispositivos dos artigos tratam apenas de um processo de mão-única de transporte, recepção, consulta e alocução, mas não do processo de mão dupla, que é a conversação (Hamelink, 2005, p. 143). 
A segunda aproximação pode ser nomeada como tática-normativa: esta visão não nega a positivação do direito à comunicação como princípio jurídico, mas prega o uso do termo mais como uma tática de abordagem política e jurídica ao tema, para que, mesmo sem a sua positivação nas normas existentes, possa ser interpretado e aplicado legalmente.

Estas duas abordagens são, de forma geral, as existentes no Brasil (Brittos, 2005).

Já a terceira abordagem nega as duas primeiras e entende que o direito à comunicação é somente um novo rótulo para a liberdade de expressão e informação. Os mais fortes adeptos desta tese defendem ser problemática a criação de um novo princípio legal, alegando que isso poderia enfraquecer ou pôr em risco o direito à liberdade de expressão protegido pela Declaração Universal dos Direitos Humanos. Não à toa, esta terceira abordagem é defendida por organizações inglesas e norte-americanas com forte e reconhecida tradição liberal, como a organização não governamental britânica Article 19.

Fischer (1982), em alusão aos debates conduzidos no âmbito da UNESCO, também captou preferências por essa direção interpretativa: “[...] Muitas das pessoas que já estavam engajadas nos estudos e debates da ONU sobre a liberdade de informação e sobre o livre fluxo de informação recearam que a introdução do novo conceito confundiria e procrastinaria suas deliberações” (1982, p. 28).

Não havia consenso inclusive entre os componentes da Comissão, em relação a citar ou não o direito no informe final. O representante da antiga União Soviética, Sergei Losev, por exemplo, afirmou que “o Direito à Comunicação não é um direito internacional reconhecido, nem no plano nacional, nem no internacional. Por conseguinte, não deveria ser examinado tão amplamente, nem abordado desse modo em nosso relatório” (UNESCO, 1983, p. 290). O informe final, mesmo assim, apresentou a sua definição do direito à comunicação.

É preciso pontuar, nesse sentido, que a própria abordagem referente ao direito à comunicação sofreu mudanças para se adequar às demandas impostas pela realidade concreta. Na língua inglesa, o termo inicialmente cunhado, right to communicate (direito de 
comunicar) foi sendo progressivamente substituído por communication rights (direitos à comunicação), o que inequivocamente amplia o escopo do conceito. Mais do que uma questão semântica, está expressa nessa mudança uma alteração na abordagem: diferentemente dos anos 70, hoje busca-se tratar de uma série de direitos que devem ser considerados em conjunto, entendidos a partir de sua complementariedade e indivisibilidade.

Nas línguas portuguesa e espanhola ${ }^{86}$, embora durante as décadas de 1970 vigorasse um debate sobre qual a melhor expressão a se utilizar, consolidou-se o uso dos termos direito à comunicação e derechos a la comunicación, que, assim como a segunda formulação na língua inglesa, define com maior clareza a compreensão de tratar-se de um conjunto de direitos ligados ao campo da comunicação (Intervozes, 2005).

É importante atentar, também, para o fato do direito à comunicação não se confundir com o direito da comunicação social, que se consubstancia em uma especialidade do Direito relativa aos princípios, normas e regras aplicáveis à comunicação social (Sant'anna Bitelli, 2004, p. 168).

Uma última questão pertinente se refere ao fato de que, durante quase quatro décadas, os indivíduos e grupos organizados brasileiros que atuaram por uma reforma no modelo de regulação das comunicações terem se pautado historicamente sob a bandeira da democratização da comunicação. Sob essa perspectiva, importava ampliar ao máximo o número de vozes presentes na esfera pública, em busca da maior diversidade possível de agentes produtores e difusores de informação. O termo, no entanto, embora com forte teor político, carrega em si uma limitação de escopo, sendo ela - a democratização da

\footnotetext{
${ }^{86}$ Un "Derecho a Comunicar” y los “Derechos a la Comunicación” están estrechamente relacionados, pero no son idénticos ni en su historia ni en su uso. El primero está más asociado con el debate sobre el NOMIC y apunta a la necesidad de um reconocimiento legal formal de tal derecho, como un marco general para una implementación más efectiva. También tiene un intuitivo sentido en tanto derecho humano básico. El segundo enfatiza más en el hecho de que ya existe un ordenamiento de derechos internacionales para apuntalar la comunicación, si bien muchos son demasiado a menudo ignorados y requieren de movilización activa y de afirmación. Éstos no se encuentran en conflicto, y ambos son usados por la Campana CRIS de modos matizados y complementarios (CRIS, 2005).
} 
comunicação -, embora tarefa das mais importantes, apenas uma das variáveis que compõe o amplo escopo do direito à comunicação.

Não obstante se reconheça o vínculo visceral entre democracia e direitos humanos, ensejando a compreensão de que o termos “democratização da comunicação” carrega em seu bojo o sentido da universalidade e da equidade, é certo que não delimita de forma incisiva o direito individual e coletivo de acesso aos meios de comunicação. “Democratização”, nessa perspectiva, pode garantir o direito de muitos, mas não necessariamente o direito de todos. Da mesma forma, não determina de forma inequívoca a responsabilidade por sua garantia. Já a qualificação da comunicação como um direito impõe ao Estado, de forma contundente, o dever de garantir, respeitar e fazer respeitar a dignidade humana no campo da comunicação, em todas as suas dimensões.

Por sua força análoga aos direitos sociais, a comparação com o campo da Educação é pertinente. Os conceitos de “democratização da educação" e de "direito à educação”, embora próximos, são diferentes: a “democratização da educação” pressupõe, na linguagem política comum, basicamente o acesso à escola, podendo ser estendido à compreensão que, além de universal, este acesso deve ser equânime. Já o direito à educação, engloba, além destes requisitos, uma série de outras variáveis sobre a formação escolar (e também fora dela), como a implementação de projetos pedagógicos pertinentes. A mesma analogia, embora um tanto genérica, pode ser aplicada ao campo da Saúde.

Assim, “democratização da comunicação” se consubstanciou historicamente no direito de acesso, não abrangendo dimensões cada vez mais importantes da dignidade humana no campo das comunicações citadas no capítulo anterior.

Nesta perspectiva, revela-se necessário refletir sobre a forma mais adequada de nomear aquilo que se pretende buscar. Liberdade de expressão, direito à informação, direito à comunicação, democratização da comunicação, enfim, qual a melhor forma de tratar a problemática? Tal questão vai além de uma mera diferenciação semântica. Tratam-se, 
acima de tudo, de propostas discursivas. A junção de cada palavra - direito, comunicação, liberdade, comunicações, humano, informação - carrega em seu bojo um projeto diferenciado. Mais do que apontar a necessidade de emprego de um termo específico, importa concluir que seria reducionista determinar que todas essas nomenclaturas afirmam princípios idênticos, que agregam as mesmas demandas conceituais e práticas, ou que diante da premência da ação, deve-se sacrificar a busca da nomenclatura ideal e da concepção teórica do conceito. Afinal, como atesta a Lingüística, as palavras são construções sociais que pensam e agem sobre o mundo. As terminologias, é certo, tendem a determinar o perfil da pretensão ${ }^{87}$ a qual se pode ou se prospecta exercer.

O reconhecimento do direito humano à comunicação, nesse sentido, busca não deixar dúvidas sobre a utopia a qual se pretende buscar, qual seja, a de garantir o acesso, a participação e a fruição do espaço público por todos os cidadãos e grupos sociais em condições mínimas de igualdade, em um fluxo de informações que respeite e promova integralmente os direitos humanos.

A não positivação do DHC, contudo, não pode ser encarada como um obstáculo ao respeito integral dos direitos humanos ligados ao campo da comunicação.

Em primeiro lugar, pois os diversos direitos e liberdades que o compõe, em sua ampla maioria, se encontram positivados no ordenamento jurídico nacional e podem ser invocados tanto como diretriz para políticas públicas e regulatórias quanto para a sua exigência em juízo.

Secundariamente, pois como aponta de forma inequívoca a emergente teoria dos direitos humanos, a existência de um direito humano não depende da possibilidade de se exigir o cumprimento por meio da coerção estatal. Trata-se, neste caso, da comum confusão entre direito subjetivo e pretensão. Nesta perspectiva, como aponta Clarice Duarte (2003) distinguem-se os direitos humanos dos direitos fundamentais, sendo os segundos os direitos

\footnotetext{
${ }^{87}$ O conceito de pretensão está descrito no Código Civil Alemão (\$194): “o direito de exigir de outrem uma ação ou omissão”. Não se deve confundir pretensão com ação judicial, que é um simples meio para exercê-la (Comparato, 2005).
} 
humanos reconhecidos como tais pelas autoridades políticas as quais se atribui o poder de editar normas, tanto no interior dos Estados (o parlamento, no caso dos regimes democráticos) como no plano internacional (os órgãos multilaterais). Os direitos fundamentais são, dessa forma, tão somente os direitos positivados nas constituições nacionais ou nos tratados internacionais.

Tal reserva conduz, necessariamente, à busca de uma justificativa mais profunda do que o simples reconhecimento estatal para a vigência desses direitos. Tal fundamento, afirma Comparato, "só pode ser a consciência ética coletiva, de que a dignidade da condição humana exige o respeito a certos bens ou valores em qualquer circunstância, ainda que não reconhecidos no ordenamento estatal, ou em documentos normativos internacionais” (2003, p. 59). Fosse outra a resposta - e o fundamento para a vigência dos direitos humanos dependesse de fato de seu reconhecimento nos ordenamentos jurídicos -, toda a primeira geração de direitos, composta de direitos que protegiam as liberdades civis dos cidadãos contra os órgãos estatais, não teria impulsionado as lutas políticas que culminaram nas revoluções do século XVIII. De fato, como afirma o jurista, "há sempre uma tensão dialética entre a consciência jurídica da coletividade e as normas editadas pelo Estado” (Ibidem, Id.).

É fato, contudo que o reconhecimento oficial de direitos humanos pela autoridade política competente “confere, sem dúvida, muito mais segurança às relações sociais, além de exercer uma função pedagógica no seio da comunidade, no sentido de fazer prevalecer os grandes valores éticos, os quais, sem esse reconhecimento oficial, tardariam a se impor na vida coletiva” (Comparato, 2003, p. 58).

É sob essa perspectiva que, embora não seja indispensável para a garantia da dignidade humana no campo da comunicação, se considera que o reconhecimento formal do DHC, com a sua conseqüente positivação como um direito fundamental, deve ser perseguida como forma de melhor garantir a dignidade humana no campo da comunicação, impondo ao conjunto de direito e liberdades que o compõe uma unidade jurídica lógica e coerente. 


\section{4 - CONCLUSÕES}

O diálogo é este encontro dos homens, mediatizados pelo mundo, para pronunciá-lo, não se esgotando, portanto, na relação eu-tu. Esta é a razão por que não é possível o diálogo entre os que querem a pronúncia do mundo e os que não a querem; entre os que negam aos demais o direito de dizer a palavra e os que se acham negados deste direito. É preciso primeiro que, os que assim encontram negados no direito primordial de dizer a palavra, reconquistem esse direito, proibindo que este assalto desumanizante continue. Se é dizendo a palavra com que, "pronunciando" o mundo, os homens o transformam, o diálogo se impõe como caminho pelo qual os homens ganham significação enquanto homens. Por isto, o diálogo é uma exigência existencial. E, se ele é o encontro em que se solidarizam o refletir e o agir de seus sujeitos endereçados ao mundo a ser transformado $e$ humanizado, não pode reduzir-se a um ato de depositar idéias de um sujeito no outro, nem tampouco torna-se simples troca de idéias a serem consumidas pelos permutantes (Freire, 1987, p. 78 -79).

A partir das duas revoluções do final do século XVIII, o reconhecimento dos direitos humanos civis e políticos permitiu a reinstituição da legitimidade democrática; de outro lado, ao criar condições para o desenvolvimento capitalista, determinou a ascensão de um modelo necessariamente baseado na acumulação de poucos e na exclusão da maioria, em todas as esferas da vida social. O mais importante princípio jurídico reconhecido no campo da comunicação, a liberdade de expressão possui, assim, íntimos laços com o pensamento liberal e o surgimento da burguesia enquanto força política hegemônica. 
A organização da classe trabalhadora em diferentes momentos históricos culminou com o posterior reconhecimento de direitos sociais e econômicos - embora estes continuem sendo desrespeitados -, mas as comunicações nunca foram objeto de lutas sociais anticapitalistas, o que acabou por determinar, em função da dinâmica imposta pelo desenvolvimento da comunicação social enquanto atividade econômica privada, a vigência e a posterior radicalização da compreensão do conceito de liberdade de expressão como uma liberdade exclusivamente negativa.

Com o desenvolvimento comunicação de massa, a capacidade de participação da esfera pública mediada pela comunicação social, no Brasil, foi restringida às elites proprietárias destes meios de comunicação.

Nas indústrias de conteúdo e telecomunicações, a convergência acelerou o processo de oligopolização. À medida que a informação se digitalizou, tornando indistinto o transporte entre os vários meios de comunicação, a tendência passou a ser a formação de oligopólios de grupos econômicos transnacionais. No plano nacional, além da importação em grande escala de conteúdo da indústria cultural norte-americana, mantém-se a tendência de monopolização do mercado de conteúdo audiovisual e jornalístico iniciada na década de 1970.

Nesse contexto, os diferentes povos, à exceção das elites aos quais estão submetidos, foram privados da fruição plena da liberdade de expressão na esfera pública. Com a evolução da técnica e a necessidade de altos recursos financeiros para erguer instituições de mídia ou ter acesso às redes de telecomunicações, a manifestação da liberdade de expressão passou a não mais depender de um ato de vontade de indivíduos ou grupos sociais. O espaço próprio dos meios de comunicação, desprovido de sua autenticidade, foi privatizado, e o exercício da liberdade de expressão na esfera pública passou a se consubstanciar em privilégio.

O desenvolvimento acelerados das novas tecnologias e da comunicação pelas redes IP não alterou o quadro de desigualdades. À medida que a técnica se desenvolve, criam-se embaraços à produção e circulação de conteúdo pelos que possuem acesso às redes de 
telecomunicações, por meio de travas tecnológicas ou regras excessivas de controle da propriedade intelectual. De outro lado, e talvez mais grave, exclui-se parcela significativa da população do acesso a estas novas formas de produção e difusão de informação, mazela consagrada pela expressão “exclusão digital”.

O relato histórico e o quadro atual das comunicações realçam a urgência da crítica à cultura tecnológica que respalda a apoteose da velocidade e a tirania do dinheiro e da informação. Impossível imaginar que desejos abastecidos por mercadorias e suas espantosas cargas de excitação possam ser usufruídos de maneira equânime pelo conjunto da sociedade, A abundância ao nosso redor está muito longe de ser igualitária. Na selva de desigualdades em que vivemos, conexões generalizadas dependem de estágios tecnológicos e condições aquisitivas marcadamente desiguais.

A apresentação do discurso dos proprietários dos meios de comunicação nos mais relevantes momentos de debate público sobre as orientações regulatórias do Estado nacional aponta que, no Brasil, o princípio jurídico da liberdade de expressão foi capturado pelos proprietários dos meios de comunicação, que impõe uma interpretação deturpada de seu significado original, de forma a determinar que, hegemonicamente, seja compreendido como a ausência absoluta de instrumentos que regulem a atividade e imponham restrições a seus interesses econômicos. A ameaça à liberdade - em particular à liberdade de expressão e à liberdade de imprensa - tem sido identificada no espaço público como vindo exclusivamente do Estado, mesmo que estejamos vivendo um inegável momento de estabilidade das instituições democráticas.

Complementarmente, o princípio jurídico do direito à informação, desde seu reconhecimento no plano normativo, nunca logrou avançar seu escopo para além do direito a receber informações, satisfeito na medida em que a liberdade de imprensa é respeitada e exercida. Como conseqüência, não conseguiu se impor como um determinante jurídico ou político, se constituindo como um princípio acessório nas discussões públicas sobre as determinações regulatórias do setor. Estes princípios jurídicos - a liberdade de expressão, a liberdade de imprensa e o direito à informação - são largamente utilizados como 
instrumento para a perpetuação de desigualdades, não para as finalidades idealizadas por seus fundadores, qual seja, a busca da verdade e o aprimoramento da democracia.

A radicalização desta mesma lógica busca gerar confusão entre o direito fundamental à expressão e o direito das empresas privadas que atuam no setor das comunicações. Primeiro, na tentativa - bem sucedida, diga-se - de igualar a liberdade individual de expressão à liberdade de imprensa, concedendo aos proprietários dos grandes meios de comunicação a pretensa titularidade exclusiva do direito à expressão pelos meios de comunicação de massa. Como se gozassem do direito em nome e pelo povo, na exata inversão da utopia democrática.

Segundo, na tentativa de forjar a aceitação - como se costume jurídico fosse - da liberdade de expressão comercial como um direito humano, desprezando a diferença flagrante entre liberdade de expressão individual (e coletiva) e a atividade de anunciar produtos em veículos de comunicação. Neste caso e uma vez mais, os detentores do capital, ao transformar em equivalentes dois tipos totalmente distintos de informação, buscam se posicionar publicamente como se fossem os legítimos representantes do direito individual e coletivo contra a censura exercida pelo Estado.

A análise da evolução recente dos meios de comunicação social revela que a estratégia discursiva dos proprietários dos grandes meios de comunicação comerciais tem prevalecido: o marco regulatório nacional - mais do que isso, a própria orientação do Estado - se moveu historicamente à mercê de interesses privados, ora nacionais, ora internacionais. Como comprova de forma categórica o relato da história regulatória dos serviços de comunicação, a circulação de informação, à exceção de períodos episódicos, sempre foi controlada por monopólios e oligopólios privados. Seus proprietários mantiveram, e ainda mantém, influência decisiva na vida política nacional, perpetuando, no plano regulatório, um ambiente altamente favorável à maximização de seus lucros e a defesa de interesses políticos determinados. 
Organizado no plano teórico a partir das reflexões produzidas no âmbito da UNESCO em um ambiente marcado pela força dos países não alinhados, o direito à comunicação emerge como uma demanda por um fluxo mais horizontal de conteúdos entre as nações, passando a ganhar contornos cada vez mais complexos - como resultado da própria expansão dos meios de comunicação na vida dos indivíduos e sociedades -, incorporando as liberdades consagradas no campo da comunicação e, progressivamente, outros direitos, muitos dos quais já reconhecidos, mas dispersos e sem uma unidade que lhes dê sentido.

Fato é que o desenvolvimento dos meios de comunicação e sua presença cada vez maior uma quase onisciência - na vida dos indivíduos e sociedades, impuseram e continuam a impor novas necessidades regulatórias e a implementação de políticas públicas mais amplas para a garantia da dignidade humana. Neste ambiente, hoje e cada vez mais, outros tantos direitos fundamentais se relacionam e se entrelaçam com a comunicação mediada por tecnologias e suportes.

É possível compreender o direito à comunicação movimento análogo ao iniciado no final do século XIX, quando setores populares reivindicaram o reconhecimento de direitos econômicos e sociais, acrescentando às liberdades negativas conquistadas no passado a necessidade de condições mínimas de igualdade material (e não meramente formal). Enquanto alguns direitos que possuem essa perspectiva (os chamados direitos de segunda geração, ou direitos econômicos e sociais) foram sendo progressivamente reconhecidos como os direitos ao trabalho, à educação e à saúde - a comunicação social, neste mesmo período, foi apropriada pelo capital e, em países como o Brasil, também pelas oligarquias locais/regionais, percorrendo caminho inverso aos outros campos objeto de direitos humanos. Dito de outra forma, assim como os direitos sociais, econômicos e culturais significaram um avanço da liberdade rumo à igualdade, este mesmo movimento, embora tardio e com características específicas, também acabou por desaguar na reivindicação pelo reconhecimento do direito à comunicação.

Por sua capacidade de expansão e atualização, assim como pela própria necessidade de reconhecimento de direitos que se entrelaçam na esfera pública, o direito à comunicação, 
cada vez mais, se consolida como um princípio jurídico determinante para a garantia da dignidade humana no campo das comunicações.

Assim, neste início de século, o DHC se consolida como um direito guarda-chuva, composto pelos direitos e liberdades já reconhecidos e positivados no marco jurídico nacional e internacional - notadamente a liberdade de expressão e o direito à informação -, pelo acesso aos meios e conhecimentos necessários para a participação em condições de igualdade (material) no espaço público da comunicação e também pelos diferentes direitos e liberdades decorrentes do equilíbrio entre princípios jurídicos consagrados e que possuem relação direta com o campo da comunicação, como os direitos das crianças e adolescentes, o direito à cultura e ao conhecimento, o direito autoral, o direito à não discriminação, o direito à privacidade, o direito à honra e à verdade, entre outros.

Nessa perspectiva, à liberdade negativa clássica devem ser acrescentadas, para a efetivação da dignidade humana no campo das comunicações, prestações positivas do Estado que objetivem garantir condições efetivas para o exercício dos direitos e liberdades na esfera pública. Se a busca pela efetivação da liberdade de expressão guiou-se historicamente pela negação da intervenção do Estado no setor da comunicação social, o direito à comunicação impõe a necessidade de um Estado que atue para evitar privilégios e para fazer respeitar o direito à participação na esfera pública. Como implicação prática, ao Estado se impõe o dever de garantir os meios técnicos, materiais e imateriais (como o conhecimento para uma relação autônoma com os meios) para que indivíduos e grupos sociais tenham condições de produzir e veicular conteúdos que julguem pertinentes, e que estes conteúdos efetivamente circulem na esfera pública.

O direito à comunicação, então, se fortalece nesse dupla direção: de uma lado, como tentativa de resgate e revitalização dos ideais do liberalismo e, de outro, como a necessidade de reconhecimento de novas e crescentes demandas, agrupando esse conjunto de direitos sob um princípio lógico capaz de orientar de forma coerente a atuação do Estado Democrático de Direito, visando seu aprimoramento. 
Nesta perspectiva, é possível afirmar existirem elementos suficientes para justificar a reivindicação por atores políticos brasileiros deste novo direito humano como estratégia político-jurídica para a garantia da dignidade humana no campo da comunicação. Embora não possa ser considerado imprescindível, este reconhecimento se revela potencialmente como a melhor forma de tradução jurídica das necessidades para o respeito integral à dignidade humana, por favorecer uma compreensão sistêmica da relação dos seres humanos com a comunicação mediada por tecnologias e suportes.

A concepção da comunicação como direito humano está inserida numa matriz de pensamento que compreende os direitos humanos como instrumentos da luta política contra-hegemônica, por uma sociedade justa, igualitária e sem opressão de qualquer tipo. Assim como os direitos econômicos e sociais, o direito à comunicação não se realizará no capitalismo selvagem de nossos tempos, ou tampouco em Estados pouco afeitos ao respeito aos direitos individuais.

Como bem afirmou Matterlart, o DHC é “ um idéia e um ideal”, uma utopia que emerge em tempos de revolução tecnológica, que, parece claro, pode tanto emancipar a humanidade quanto perpetuar ou mesmo radicalizar as desigualdades que movem as conhecidas violações à dignidade humana.

Concluí-se, assim, que o direito humano à comunicação deve ser tomado como um dos pilares centrais de uma sociedade que se pretenda democrática e, conseqüentemente, como conceito orientador da organização de um modelo institucional para a área das comunicações.

O DHC é, acima de tudo, a busca da utopia da comunicação autêntica preconizada por Paulo Freire.

Julga-se, por fim, que dentre as perguntas e questões expostas como motivadoras desta dissertação, parte delas - as que buscam justificar a emergência do DHC e apresentar suas características essenciais - foram razoavelmente investigadas e respondidas, embora não 
tenham, de forma alguma, fechado portas para novas pesquisas e conclusões sobre as mesmas questões.

Por outro lado, se considera que a investigação sobre a titularidade e a qualificação jurídica do direito à comunicação, embora tenha sido objeto de pesquisa, não atingiram o nível de maturidade inicialmente esperado, ficando esta tarefa em aberto para futuras investigações deste ou de outros pesquisadores interessados no tema. Outras janelas ainda devem ter ficado em aberto.

De qualquer forma, espero que esta dissertação contribua, mesmo que timidamente, para o debate sobre o tema, no meio acadêmico, no meio político e no âmbito das entidades da sociedade civil que atuam na defesa dos direitos humanos. 


\section{5 - REFERÊNCIAS BIBLIOGRÁFICAS}

ADORNO, Theodor (1971). A indústria cultural. In: COHN, Gabriel. Comunicação e Indústria Cultural. São Paulo: Edusp.

AFONSO, Carlos (2002). Internet: quem governa a infra-estrutura?. São Paulo: Fundação Friedrich Ebert. ALEXY, Robert (2008). Teoria dos direitos fundamentais. São Paulo: Malheiros Editores.

ALMINO, João (1986). O segredo e a informação: ética e política no espaço público; São Paulo: Brasiliense. AMORIM, José Salomão David (1986). Comunicação e transição no Brasil - propostas de mudanças de políticas de comunicação. In: Outros textos sobre políticas de comunicação. Textos de Cultura e Comunicação. n. 11. Salvador: Nicom/UFBA.

ANATEL, Conselho Consultivo (2007). Relatório Sobre Convergência e Conteúdo Eletrônico. Brasília: Agência Nacional de Telecomunicações.

ANCINE (2006). Relatório de gestão 2006. Rio de Janeiro: Agência Nacional de Cinema.

ANCINE (2006), Nota Técnica. Rio de Janeiro: Agência Nacional de Cinema.

ARIENTE, Eduardo Altomare (2008). Direito à Comunicação no Brasil. Dissertação de mestrado. Universidade de São Paulo: São Paulo.

BANCO MUNDIAL e OECD (1999). A Framework for the Design and Implementation of Competition Policy. Banco Mundial.

BANDEIRA DE MELLO, Celso Antônio (2000). Curso de Direito Administrativo, $13^{\mathrm{a}}$ Edição, São Paulo: Malheiros Editores.

BARENDT, Eric (1985). Freedom of Speech. Oxford: Clarendom Press.

BECERRA, Martín (2003). Sociedad de la información: proyecto, convergência, divergência. Enciclopédia Latinoamericana de Sociocultura y Comunicación. Buenos Aires: Grupo Editorial Norma.

BENEVIDES, Maria Victoria de Mesquita (1994). Cidadania e Democracia. São Paulo, n 33, Lua Nova. (2004). Conversando com os jovens sobre direitos humanos. In: Paulo Vanucchi; Regina Novaes. (Org.). Juventude e sociedade. São Paulo: Perseu Abramo, p. 34-52. (2002). Democracia e Direitos humanos no Brasil, In: Especial Democracia Caros Amigos, ano VI No 15, p.12, São Paulo, Ed. Casa Amarela.

BENEVIDES, Maria Victoria de Mesquita e COMPARATO, Fábio Konder (2009). A dignidade humana como fonte de direitos. In: MACIEL DE BARROS, G. N. (org.). Estudos em homenagem a Celso Beisiegel, São Paulo: EDUSP.

BENJAMIM, Walter (1980). A obra de arte da época de suas técnicas de reprodução. In: BENJAMIM, Walter; HORHEIMER, Max; ADORNO, Theodor W; HABERMAS, Jürgen. Textos escolhidos (Os Pensadores). São Paulo: Abril.

BRIGGS, Asa e BURKE, Peter (2002). Uma história social da mídia: de Gutenberg à Internet. Rio de Janeiro: Jorge Zahar Editor. 
BENKLER, Yochai (2006). The Wealth of Networks: How Social Production Transforms Markets and Freedom. New Haven CT: Yale University Press.

BENKLER, Yochai (2007). A economia política dos commons. In: Comunicação digital e a construção dos commons. São Paulo: Editora Fundação Perseu Abramo.

BOBBIO, Norberto (1992). A Era dos Direitos. Rio de Janeiro: Campus.

(1998). Liberalismo e democracia. São Paulo: Brasiliense.

(1996). Igualdade e Liberdade. Rio de Janeiro: Ediouro.

BOLAÑO, César Ricardo Siqueira (2000). Indústria Cultural, Informação e Capitalismo. São Paulo:

Hucitec/Polis.

(2003). Políticas de comunicação e economia política das telecomunicações no Brasil.

São Paulo: HUCITEC.

(2004). A Economia Política da Internet e sua Crise. In: Comunicação, Informação e

Cultura - dinâmicas globais e estruturas de poder. Salvador: EDUFBA.

BRANT, João (2002). Políticas nacionais de radiodifusão (1985-2001) e espaço público. Trabalho de conclusão de curso. São Paulo: Escola de Comunicações e Artes/USP.

BRECHT, Bertold (2005). Teoria do rádio (1927 - 1932). In: MEDITSCH, Eduardo (org). Teorias do Rádio: textos e contextos - Volume I. Florianópolis: Insular.

BRITTOS, Valério Cruz (2003). Oligopólios midiáticos: a televisão contemporânea e as barreiras à entrada. São Leopoldo: Cadernos IHU idéias.

BRONCANO, Fernando (2000). Mundos artificiales: filosofia del cambio tecnológico. Barcelona: Paidós.

BUCCI, Eugênio (2008). Em Brasília, 19 horas: A Guerra entre a Chapa-Branca e o Direito à Informação no primeiro governo Lula. São Paulo: Record.

(2008). Direito de livre expressão e direito social à informação na era digital. São

Paulo: Faculdade Cásper Líbero - Ano XI - nº 22.

BUCCI, Eugênio; KEHL, Maria Rita (2005). Videologias. São Paulo: Boitempo.

CADE (2008). A Convergência Tecnológica e seus Impactos Concorrenciais. Relatório de Audiências Públicas.

CANCLINI, Néstor García (1997) Consumidores e Cidadãos, Conflitos Multiculturais da Globalização, Rio de Janeiro, Ed. UFRJ

(2004). Diferentes, desiguales y desconectados: mapas de la interculturalidad.

Barcelona: Gedisa.

CASTELLS, Manuel (2003). A sociedade em rede - A era da informação: economia, sociedade e cultura. São Paulo: Ed. Paz e Terra.

CHAUÍ, Marilena (2006). Simulacro e poder: uma análise da mídia. São Paulo: Editora Perseu Abramo.

COMPARATO, Fábio Konder (2003). A Afirmação Histórica dos Direitos Humanos, São Paulo, Saraiva. (2006). Ética, direito, moral e religião no Mundo Moderno. São Paulo: Companhia das Letras. 
(2002) A Subjetividade dos Direitos Humanos, Curso de Especialização em Direitos Humanos, Aula II, Faculdade de Direito/USP (2001) A democratização dos meios de comunicação de massa. In: Estudos em Homenagem a Paulo Bonavides, Malheiros e Revista da USP. (1994). Nótula sobre o direito à comunicação social. In: CAVALCANTI FILHO, José Paulo (org). Informação e Poder; São Paulo: Editora Record. COSTA, Alexandre Araújo; COSTA, Henrique Araújo (2008). Direito da Puclicidade. Brasília: Thesauros Editora.

CPqD (2006). Cartografia Audiovisual Brasileira de 2005 - Um estudo quali-quantitativo de TV e cinema. Campinas: CPQD.

DALLARI, Dalmo de Abreu (2003), Elementos de Teoria Geral do Estado. São Paulo: Ed. Saraiva (2002). O Aparato Jurídico da Democracia. In: Especial Democracia Caros Amigos, ano VI No 15, p.12, São Paulo, Ed. Casa Amarela. (2001). Liberdade e intimidade: direitos fundamentais. Folha de S. Paulo, São Paulo, p.

3, 06/08/2001.

DANTAS, Marcos (2002). A lógica do capital-informação: a fragmentação dos monopólios e a monopolização dos fragmentos num mundo de comunicações globais. São Paulo: Contraponto. DUARTE, Clarice (2003). Direito Público Subjetivo ao Ensino Fundamental na Constituição Federal de 1988. Tese de Doutorado. Faculdade de Direito, Universidade de São Paulo.

ENCONTRO NACIONAL DE DIREITOS HUMANOS, 2005, Brasília. Carta de Brasília. Disponível em: Www.crisbrasil.org.br. Acesso em: 10 set. 2006.

FARIAS, Edison Pereira de (2000). Colisão de direitos: a honra, a intimidade, a vida privada e a imagem versus a liberdade de expressão e informação. Porto Alegre: Sérgio Antonio Fabris.

fundamentais na Constituição Brasileira. $1^{\mathrm{a}}$ ed., São Paulo: Instituto Brasileiro de Direito Constitucional. FERREIRA, Aluízio (1997). Direito à informação, Direito à comunicação: direitos fundamentais na constituição brasileira. São Paulo: Instituto Brasileiro de Direito Constitucional.

FISHER, Desmond (1984). O direito de comunicar: Expressão, informação e liberdade. São Paulo:

Brasiliense.

FREIRE, Paulo. Extensão ou Comunicação? (1983). Rio de Janeiro: Paz e Terra. (1967). Educação como Prática da Liberdade. Rio de Janeiro: Paz e Terra.

GINDRE, Gustavo (2007). Agenda de Regulação: Uma proposta para o debate. In: Comunicação digital e a construção dos commons. São Paulo: Editora Fundação Perseu Abramo.

GIOVANNINI, Giovanni (1987). Evolução na Comunicação: do sílex ao silício. Rio de Janeiro: Nova Fronteira.

GOMES, Raimunda Aline Lucena (2008). A comunicação como direito humano: um conceito em construção. Dissertação de mestrado. Recife: Universidade Federal de Pernambuco. 
GOMES, Wilson (1998a). Esfera pública política e media: com Habermas, contra Habermas. In Rubim, A.C.C. et alli (org). Produção e recepção dos sentidos midiáticos. Petrópolis, Vozes/Compós, 1998, p. 155186.

(1998b) Esfera pública política e media II. IV Compós. São Paulo, 1998, mimeo.

HABERMAS, Jurgen (1984), Mudança Estrutural da Esfera Pública, Rio de Janeiro: Ed. Tempo Brasileiro (1988). Teoria de La Acción Comunicativa. Racionalidad de La Acción y

Racionalización Social. Madrid: Taurus. Tomo I.

(1997). O papel da sociedade civil e da esfera pública política in Direito e Democracia: entre facticidade e validade, volume II. Rio de Janeiro: Tempo Brasileiro, pp.57-121.

HALL, Stuart (1989). Ideology and Communications Theory. In. DERVIN, B: Re-thinking Communication: Paradigm Issues, Vol. 1, Sage B. Hills

(2005). A identidade cultural na pós-modernidade. Rio de Janeiro: DP\&A.

HAMELINK, C.J (2005). Direitos Humanos para a Sociedade da Informação. In: MARQUES DE MELO, José; SATHLER, Luciano (Orgs.). Direitos à Comunicação na Sociedade da Informação. São Bernado do Campo: UMESP.

HERZ, Daniel (1987). A história secreta da Rede Globo. Porto Alegre: Editora Tchê.

(1997). A renúncia a uma política de telecomunicações, em nome da telefonia e da radiodifusão. Texto apresentado no GT de Políticas Públicas de Comunicação da INTERCOM. Porto Alegre. HOPENHAYH, Martín (2002). Educación y cultura em Iberoamérica: situación, cruces y perspectivas. In: CANCLINI, Néstor García (org.) Iberoamérica 2002: diagnóstico y propuestas para el desarrollo Cultura. México, Santillana.

INTERVOZES (2005). Direito à Comunicação no Brasil: Base constitucional e legal, implementação, o papel dos diferentes atores e tendências atuais e futuras. São Paulo: Intervozes - Coletivo Brasil de Comunicação Social.

(2007) Concessões de Rádio e TV: onde a democracia ainda não chegou. Intervozes -

Coletivo Brasil de Comunicação Social.

KUCINSKI, Bernardo (2002). Mídia e democracia no Brasil. In: Margarida Krohling Kunsch e Roseli Fischmann (orgs.). Mídia e Tolerância: a ciência construindo caminhos de liberdade. São Paulo: EDUSP. LAFER, Celso (1991). Ensaios Liberais. São Paulo: Siciliano.

LEAL F., Laurindo ( 2008). Alô, Repórter Esse, alô. In Retrato do Brasil, nº 17, Dezembro/2008, p. 43.

LESSIG, Lawrence (2001). The future of ideas: the fate of commons in a connected world. New York: Random House.

LÉVY, Pierre. A Inteligência Coletiva. São Paulo: Editora 34, 2000.

LIMA, Paulo Henrique (2004). Sociedade da Informação, Democracia e Igualdade. In: LIMA, Paulo Henrique; SELAIMEN, Graciela. Cúpula Mundial sobre a Sociedade da Informação. Rio de Janeiro: Rits. LIMA, Venício Artur de (2001). Mídia, Teoria e Política. São Paulo; Perseu Abramo. (2006) Mídia: crise política e poder no Brasil. São Paulo: Perseu Abramo. 
(1981). Comunicação e Cultura: as idéias de Paulo Freire. Rio de Janeiro: Paz e

Terra.

(2008). Sobre a "liberdade de expressão comercial". In: Observatório da Imprensa, acessado no Portal Vermelho em 25.07.2008.

(2009). Liberdade de Expressão vs. Liberdade de Imprensa: o sentido das idéias. São Paulo, Observatório da Imprensa.

LOPES, Vera Maria de Oliveira Nusdeo (2000). A lei da selva, In: Eugênio Bucci (org.). A TV aos 50:

criticando a televisão brasileira no seu cinqüentenário. São Paulo: Fundação Perseu Abramo.

MATTELART, Armand (1994). Comunicação-Mundo: história das técnicas e das estratégias. Petrópolis, Vozes.

MATTELART, Armand; MATTELART, Michele (1999). História das teorias da comunicação. São Paulo, Edições Loyola.

MATTOS, Sérgio (2002). História da Televisão Brasileira: uma visão econômica, social e política. $2^{\mathrm{a}}$ ed. Petrópolis: Vozes

MARX, Karl e ENGELS, Friedrich (1977). Textos (3 vols.). São Paulo: Edições Sociais.

MELO, José Marques de (1976). Ciências da Informação, in Comunicação Social: teoria e pesquisa, $2^{a}$ ed., Petrópolis: Vozes.

MELO, José; SATHLER, Luciano (Orgs.) (2005). Direitos à Comunicação na Sociedade da Informação. São Bernardo do Campo: UMESP.

MELO, Patricia Bandeira (2005). Um passeio pela História da Imprensa: o espaço público dos grunhidos ao ciberespaço. Comunicação e informação, V 8, nº 1 pág 26 - 38. - jan/ jun.

MIÈGE, Bernard (2000). O pensamento comunicacional. Petrópolis: Vozes.

MILL, Stuart John (2000a) A Liberdade Utilitarismo. São Paulo, Martins Fontes. (2000b) Sobre a liberdade. São Paulo, Martins Fontes. (1976). Da Liberdade de Pensamento e de Expressão. $2^{\mathrm{a}}$ ed. Lisboa: Dom Quixote.

MILTON, John (1999). Areopagítica - Discurso pela Liberdade de Imprensa ao Parlamento da Inglaterra. Rio de Janeiro: Topbooks.

MORAES, Dênis de (2009). A Batalha da Mídia. Rio de Janeiro: Pão e Rosas.

MOREIRA, Vital (1994). O direito de resposta na comunicação social. Coimbra: Coimbra Editora.

NERONE, John C (1995). Last Rights: Revisiting Four Theories of the Press. Urbana: University of Illinois Press, 1995.

OECD (2006). Policy Considerations for audio-visual content distribution in a multiplataform environment. Organisation for Economic Co-operation and Development.

ORTIZ, Renato (2003). Mundialização e cultura. São Paulo: Brasiliense.

PARETO NETO, João Victorio (1976). Meio século de telecomunicações. Telebrasil, mar./abr, p. 27-39. PIERANTI, Octavio Penna (2006). Políticas para a mídia: dos militares ao governo Lula. Lua Nova, 68. 
RAMOS, Murilo César (1992). "Lês Politiques Nationales de Communication e la Crise des Paradigmes", in L'Amérique et les Amériques. Por Jacques Zylberberg e François Demérs (Orgs.), pp. 136-149. Québec: Les Presses de L'Université Laval.

(2006). Crítica do ambiente político-regulatório da comunicação social eletrônica brasileira: fragmentação política e dispersão regulamentar. In: Classificação Indicativa no Brasil. Brasília: Ministério da Justiça.

ROCHA, Maria Eduarda da Mota (2005). O Canto da Sereia - Notas sobre o discurso neoliberal na publicidade brasileira pós-1990, Revista Brasileira de Ciências Sociais, nº 64, junho de 2007.

RODRIGUES, Diogo Moyses (2009). A Convergência Tecnológica das Telecomunicações e os Direitos do consumidor no Brasil, São Paulo: IDEC.

PEREIRA, Sivaldo; RODRIGUES, Diogo Moyses; VALENTE, Jonas (2009). Sistemas Públicos de Comunicação no Mundo: doze experiências e o caso brasileiro, São Paulo: Paulus.

SABAU, José Ramón Polo (2002). Libertad de expresión y derecho de acceso a los medios de comunicación. Madrid: Centro de Estudios Políticos y Constitucionales.

SANT’ANNA BITELLI, Marcos Alberto (2005). Coletânea de Legislação de Comunicação Social. $5^{\mathrm{a} e d . ~ S a ̃ o ~}$ Paulo: Revista dos Tribunais.

SALOMÃO F., Calixto (2002). Regulação e Desenvolvimento. São Paulo, Malheiros Editores.

SANTOS, Suzy dos (2005). O dono do mundo: O Estado como proprietário de televisão no Brasil. XXVIII Congresso Brasileiro de Ciências da Comunicação - Intercom. Rio de Janeiro, Intercom - Sociedade Brasileira de Estudos Interdisciplinares da Comunicação. (www.intercom.org.br).

SARMENTO, Daniel (2006). A liberdade de expressão e o problema do 'Hate Speech', in Livres e Iguais: estudos de direito constitucional, Rio de Janeiro, Lumen Júris.

SCHAFF, Adam Schaff (1992). A sociedade informática, São Paulo: Brasiliense/Unesp.

SILVEIRA, Sérgio (2003). Inclusão digital, software livre e globalização contra-hegemônica. In: Software Livre e Inclusão Digital. São Paulo: Conrad Editora do Brasil.

(2007). Redes virais e espectro aberto: descentralização e desconcentração do poder comunicacional. In: Comunicação digital e a construção dos commons. São Paulo: Editora Fundação Perseu Abramo.

SOUSA, Mauro Wilton de (2006). A recepção sendo reinterpretada. In: Recepção Mediática e Espaço Público. São Paulo: Paulinas, p. 13-26

(2006). Práticas de Recepção Mediática como Práticas de Pertencimento Público. In:

Recepção Mediática e Espaço Público. São Paulo: Paulinas, p. 215-242.

SOUSA SANTOS, Boaventura de (2002). Democratizar a Democracia. Rio de Janeiro: Civilização Brasileira. SUIAMA, Sérgio Gardenghi (2002). A voz do dono e o dono da voz: o direito de resposta coletivo nos meios de comunicação, Boletim Científico da Escola Superior do Ministério Público da União n. ${ }^{\circ}$ 05, outubro/dezembro de 2002.

TOCQUEVILLE, Alexis de (1987). A Democracia na América. São Paulo: EDUSP. 
TOME, takashi (1991). Pequena história da telefonia no Brasil. Cadernos de Política Tecnológica da AFECPqD, mar, pág 1-4.

TRABERS, Michael (1999). A Comunicação é Parte da Natureza Humana - Uma Reflexão Filosófica a Respeito do Direito a se Comunicar. In: Idoc Internazionale, Vol. 30, Nos. 1 \& 2, January-June 1999. Rome: IDOC, 1999.

UNESCO (1983) Um Mundo e Muitas Vozes: comunicação e informação na nossa época. Comissão Internacional para o Estudo dos Problemas da Comunicação. Rio de Janeiro, FGV.

(2005). Resolutions, Decisions (1946 -2005). Paris: Clearing House. 1 CD-ROM.

WILLIAMS, Raymond (1979). Marxismo e literatura. Rio de Janeiro: Jorge Zahar.

WOLF, Mauro (1995). Teorias da comunicação. Lisboa: Editorial Presença.

WOLTON, Dominique (2004). Pensar a comunicação. Brasília: UnB.

ZYLBERSZTAJN, Joana (2008). Regulação de mídia e colisão entre direitos fundamentais. Dissertação de mestrado. São Paulo: Universidade de São Paulo.

\section{$\underline{\text { Sítios e portais pesquisados }}$}

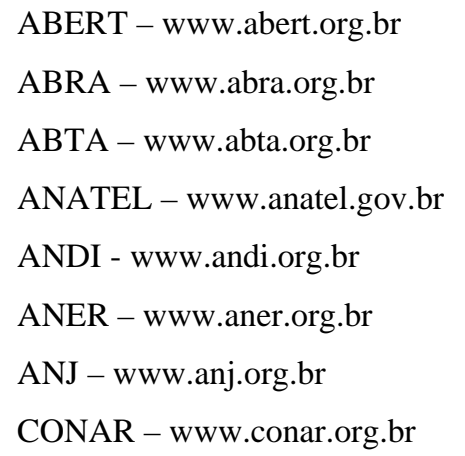

Cris Campaign - www.crisinfo.org

Cris Brasil (Articulação Nacional pelo Direito à Comunicação) - www.crisbrasil.org.br

Cúpula Mundial sobre a Sociedade da Informação (CMSI) - www.cmsi.org.br

Dono da mídia - www.donosdamidia.com.br

FNDC - www.fndc.org.br

Folha de S. Paulo - www.folhasp.com.br

Instituto Alana - www.alana.org.br

Intervozes - www.intervozes.org.br

Ministério das Comunicações - www.mc.gov.br

Ministério da Cultura - www.cultura.gov.br

MST - www.mst.org.br 
Organização das Nações Unidas - www.un.org

Organização Mundial do Comércio - www.wto.org

Organização Mundial de Propriedade Intelectual - www.wipo.org

O Estado de S. Paulo - www.estadao.com.br

O Globo - www.oglobo.com.br

Observatório da Imprensa - www.observatoriodaimprensa.org.br

Observatório do Direito à Comunicação - www.direitoacomunicacao.org.br

Telaviva News - www.telaviva.com.br

Telesintese - www.telesintese.com.br

Teletime News - www.teletime.com.br

UNESCO - www.unesco.org

Veja - www.veja.com.br 


\begin{abstract}
ANEXO 1
Quadro genérico de referência do direito à comunicação: atributos e indicadores
\end{abstract}

Campanha CRIS, 2005 


\title{
QUADRO GENÉRICO DE REFERÊNCIA DO DIREITO À COMUNICAÇÃO
}

\author{
$\underline{\text { Atributos e Indicadores }}$
}

\begin{tabular}{|c|c|}
\hline \multicolumn{2}{|c|}{$\begin{array}{c}\text { Pilar A } \\
\text { Criação de espaços para ambientes democráticos: a esfera pública }\end{array}$} \\
\hline Atributos do Direito à Comunicação & $\begin{array}{l}\text { Indicadores de um ambiente propício } \\
\text { para o direito à comunicação }\end{array}$ \\
\hline $\begin{array}{l}\text { A1 - Liberdade de expressão, inclusive uma } \\
\text { atmosfera de abertura e o direito a criticar aqueles no } \\
\text { poder. }\end{array}$ & $\begin{array}{l}\text { A1.1 - Provisão constitucional e leis que garantam a } \\
\text { liberdade de expressão. } \\
\text { A1.2 - A ausência de ações governamentais ou de } \\
\text { empresas que restrinjam a liberdade de expressão e a } \\
\text { garantia ativa do cumprimento das leis de liberdade } \\
\text { de expressão. } \\
\text { A1.3 - Medidas ativas para a promoção de uma } \\
\text { atmosfera de abertura e discussão ampla. }\end{array}$ \\
\hline $\begin{array}{l}\text { A2 - Liberdade de imprensa e mídia, inclusive para } \\
\text { jornalistas realizarem seu trabalho e } \\
\text { responsabilidades relacionadas. }\end{array}$ & $\begin{array}{l}\text { A2.1 - Provisão constitucional e/ou leis que } \\
\text { garantam a liberdade da imprensa e de todos os tipos } \\
\text { de mídia, além de independência editorial, com o } \\
\text { mínimo de restrições, incluindo a proibição de } \\
\text { monopólios em qualquer mídia. } \\
\text { A2.2 - Medidas para prevenir a violação de direitos } \\
\text { humanos dos jornalistas na execução de seu } \\
\text { trabalho, especialmente em áreas de conflito. } \\
\text { A2.3 - Medidas para apoiar a liberdade editorial de } \\
\text { jornalistas, inclusive segurança no emprego, } \\
\text { sindicalização, direitos morais de autor e resistência } \\
\text { à coerção moral e outras formas de coerção por parte } \\
\text { de empregadores ou outrem. } \\
\text { A2.4 - Instrumentos independentes e medidas que } \\
\text { assegurem o direito de resposta, que protejam o } \\
\text { público contra processos difamatórios, protejam a } \\
\text { privacidade e evitem o incitamento à violência, e } \\
\text { outras provisões contidas em acordos internacionais. } \\
\text { A2.5 - Medidas para prevenir censura por parte de } \\
\text { entidades comerciais de material relevante para a } \\
\text { esfera pública, inclusive de conteúdo eletrônico e } \\
\text { para a internet - por parte, por exemplo, de } \\
\text { provedores de acesso à internet, mecanismos de } \\
\text { busca e provedores de banda (infra-estrutura } \\
\text { de internet, empresa de telefonia, internet a cabo ou } \\
\text { via satélite). }\end{array}$ \\
\hline $\begin{array}{l}\text { A3 - Acesso e pronta disponibilidade de informações } \\
\text { públicas e governamentais, de modo abrangente, útil } \\
\text { e rápido, especialmente no que concerne ao } \\
\text { desenvolvimento e implementação de políticas e } \\
\text { questões de interesse público, como saúde, } \\
\text { segurança etc. }\end{array}$ & $\begin{array}{l}\text { A3.1 - Legislação sobre liberdade da informação, } \\
\text { com a mínima retenção por parte de órgãos públicos } \\
\text { e governamentais, e com acesso máximo por parte } \\
\text { do mais amplo público. } \\
\text { A3.2 - A implementação de tais leis que tornem tal } \\
\text { informação disponível de maneira acessível }\end{array}$ \\
\hline
\end{tabular}




\begin{tabular}{|c|c|}
\hline & $\begin{array}{l}\text { economicamente e em tempo correto para todos. } \\
\text { A3.3 - Esforços ativos por parte dos setores público } \\
\text { e estatal para expandir a abertura e a transparência, } \\
\text { inclusive através de meios como: } \\
\text { - estruturas ou escritórios para reunir e divulgar } \\
\text { informações de forma apropriada; } \\
\text { - a publicação de objetivos e planejamentos de } \\
\text { políticas e serviços públicos; } \\
\text { - proteção para funcionários públicos que revelem } \\
\text { informação de e em prol do interesse público; } \\
\text { - a transmissão das deliberações dos representantes } \\
\text { eleitos e órgãos públicos; } \\
\text { - transparência do processo decisório em questões de } \\
\text { interesse público, como decisões de gabinete. } \\
\text { A3.4 - Abertura e transparência governamental em } \\
\text { negociações e instituições internacionais } \\
\text { relacionadas à mídia e à esfera pública. }\end{array}$ \\
\hline $\begin{array}{l}\text { A4 - Acesso a informações empresariais, de modo } \\
\text { abrangente e rápido, quando relevantes para o } \\
\text { interesse público. }\end{array}$ & $\begin{array}{l}\text { A4.1 - Legislação/regulamentação sobre quebra de } \\
\text { sigilo corporativo, além das informações financeiras } \\
\text { básicas, de modo a incluir informação disponível das } \\
\text { corporações que terão influência sobre políticas } \\
\text { públicas e o interesse público. }\end{array}$ \\
\hline $\begin{array}{l}\text { A5 - Diversidade, pluralidade e acesso a mídias e } \\
\text { conteúdo, assegurando um amplo espectro de visões } \\
\text { por parte de todos os setores da sociedade, inclusive } \\
\text { minorias e grupos marginalizados, e a justa } \\
\text { representação de todos os grupos, inclusive } \\
\text { mulheres, minorias e grupos étnicos. }\end{array}$ & $\begin{array}{l}\text { A5.1 - Legislação e medidas efetivas para impedir a } \\
\text { concentração da propriedade na mídia ou controles } \\
\text { por parte de qualquer interesse setorial, indivíduo ou } \\
\text { entidade, incluindo: } \\
\text { - concentração da propriedade de um tipo de mídia } \\
\text { em particular; } \\
\text { - propriedade cruzada entre mídias; } \\
\text { - propriedade cruzada da produção, disseminação de } \\
\text { conteúdo e componentes de infra-estrutura dos meios } \\
\text { de comunicação; } \\
\text { - propriedade excessiva por parte de estrangeiros e } \\
\text { empresas não-ligadas ao setor de mídia. } \\
\text { A5.2 - Um quadro legal que ampare a emergência de } \\
\text { uma pluralidade de tipos de canais e empresas em } \\
\text { nível nacional e, quando apropriado, em níveis } \\
\text { regionais (internacional) e local: canais e empresas } \\
\text { públicas, comerciais e comunitárias/ } \\
\text { independentes, inclusive a alocação de modo } \\
\text { transparente e igualitário do espectro de } \\
\text { radiofreqüências e outros bens públicos. } \\
\text { A5.3 - Medidas efetivas para assegurar que canais e } \\
\text { empresas públicas tenham disponíveis financiamento } \\
\text { e recursos adequados, especialmente em relação ao } \\
\text { noticiário e ao trato de assuntos atuais, de forma } \\
\text { completamente independente dos governos e não } \\
\text { sujeita a interferências arbitrárias, e livre de } \\
\text { regulamentações desnecessariamente pesadas. } \\
\text { A5.4 - Medidas efetivas que assegurem que } \\
\text { empresas e canais comunitários e sem fins lucrativos } \\
\text { tenham recursos adequados, inclusive bens públicos } \\
\text { como o espectro de freqüências; estejam livres de } \\
\text { interferências arbitrárias; } \\
\text { sejam transparentes, democráticos e participativos; e } \\
\text { apóiem e tenham participação de comunidades }\end{array}$ \\
\hline
\end{tabular}




\begin{tabular}{|c|c|}
\hline & $\begin{array}{l}\text { excluídas e marginalizadas. } \\
\text { A5.5 - Obrigações regulatórias aplicáveis sobre } \\
\text { empresas e canais comerciais, inclusive difusores, } \\
\text { quando apropriado, para assegurar o cumprimento } \\
\text { dos requisitos da prestação de serviço público. } \\
\text { A5.6 - Medidas efetivas para assegurar } \\
\text { acessibilidade, até mesmo econômica, às mídias } \\
\text { relevantes (inclusive jornais e televisão) e conteúdos, } \\
\text { especialmente por parte de grupos culturais e } \\
\text { lingüísticos marginalizados. Por exemplo, regimes } \\
\text { de impostos diferenciados, difusão livre em TV } \\
\text { aberta, obrigar os operadores de rede a aceitar os } \\
\text { canais (must carry) etc. } \\
\text { A5.7 - Medidas efetivas, de acordo com a } \\
\text { necessidade, para enfrentar a representação } \\
\text { inadequada ou torpe de mulheres, grupos étnicos, } \\
\text { grupos mais pobres e marginalizados por parte da } \\
\text { mídia. } \\
\text { A5.8 - Apoio a medidas nas instituições e fóruns } \\
\text { multilaterais que assegurem a proteção e o apoio a } \\
\text { mídias nacionais, inclusive o direito a discriminar } \\
\text { em favor de empresas e canais locais, e a regulação } \\
\text { de conteúdo estrangeiro. } \\
\text { A5.9 - Medidas efetivas para impedir que a } \\
\text { propaganda exerça uma influência negativa sobre a } \\
\text { esfera pública, por exemplo com a identificação } \\
\text { ostensiva, limitação do volume de propaganda e de } \\
\text { conteúdo político ou religioso. Os gastos públicos } \\
\text { em propaganda também podem ser usados } \\
\text { para apoiar a esfera pública. }\end{array}$ \\
\hline $\begin{array}{l}\text { A6 - Participação efetiva por parte de todos os } \\
\text { elementos da sociedade civil na preparação, } \\
\text { implementação e avaliação de estruturas e políticas } \\
\text { de governança da mídia. }\end{array}$ & $\begin{array}{l}\text { A6.1 - Consultas públicas abertas e extensivas e } \\
\text { participação no desenvolvimento de políticas para a } \\
\text { mídia, inclusive em instituições e fóruns inter- } \\
\text { governamentais. } \\
\text { A6.2 - Meios efetivos e dinâmicos que façam com } \\
\text { que preocupações e reclamações públicas sejam } \\
\text { ouvidas e atendidas, de acordo com as políticas de } \\
\text { mídia. } \\
\text { A6.3 - Mecanismos permanentes para participação } \\
\text { independente e direta do público na revisão e } \\
\text { implementação de políticas em curso, de modo } \\
\text { descentralizado quando apropriado - por exemplo, } \\
\text { através de conselhos públicos e conferências } \\
\text { públicas periódicas, que contem com ampla } \\
\text { participação da sociedade civil. } \\
\text { A6.4 - Mecanismos e instrumentos de auto- } \\
\text { governança, desenvolvidos e utilizados pela } \\
\text { sociedade civil, reconhecidos ou não pelo governo. }\end{array}$ \\
\hline
\end{tabular}




\section{Pilar B \\ Retomando o uso do conhecimento e do domínio público}

\begin{tabular}{|c|c|}
\hline Atributos do Direito à Comunicação & $\begin{array}{l}\text { Indicadores de um ambiente propício } \\
\text { para o direito à comunicação }\end{array}$ \\
\hline $\begin{array}{l}\text { B1 - Um regime equilibrado de partilha do } \\
\text { conhecimento que assegure que o conhecimento } \\
\text { gerado ou disseminado por empresas, canais e } \\
\text { setores de comunicação esteja disponível para } \\
\text { todos de modo igualitário e acessível } \\
\text { financeiramente, e que encoraje a criatividade da } \\
\text { forma mais ampla possível por toda a sociedade. }\end{array}$ & $\begin{array}{l}\text { B1.1 - Uma estratégia nacional e uma orientação } \\
\text { política com relação a criação, disseminação e uso } \\
\text { do conhecimento (especialmente copyright, } \\
\text { incluindo materiais e softwares educacionais } \\
\text { publicados) cujos objetivos explícitos sejam } \\
\text { enriquecer o domínio público, satisfazer as várias } \\
\text { necessidades de conhecimento e encorajar a } \\
\text { criatividade de todos os setores da sociedade. Isto } \\
\text { pode ser expresso em termos de posições e políticas } \\
\text { sobre Direitos de Propriedade Intelectual (IPR) em } \\
\text { uma ‘sociedade da informação’, em mídia e outras } \\
\text { áreas, tanto em organizações nacionais como } \\
\text { internacionais, acordos e tratados. }\end{array}$ \\
\hline B2 - Medidas práticas para implementar este regime. & $\begin{array}{l}\text { B.2.1 - Políticas públicas e ações para encorajar e } \\
\text { possibilitar a mais ampla e difusa geração e } \\
\text { comunicação do conhecimento, que podem incluir: } \\
\text { - modos de celebrar bons trabalhos por parte de } \\
\text { profissionais e do público; } \\
\text { - incentivos públicos para pesquisa e criação local/ } \\
\text { nacional do conhecimento em áreas de reconhecida } \\
\text { necessidade; } \\
\text { - instrumentos públicos para facilitar o acesso ao } \\
\text { conhecimento, inclusive uma política de } \\
\text { disseminação de conteúdo de interesse público; } \\
\text { - apoio público para software livre e de código } \\
\text { aberto } \\
\text { - por exemplo através de uma política pública de } \\
\text { provisão - e para o desenvolvimento de especialistas } \\
\text { nacionais; } \\
\text { - currículos escolares que encorajem métodos } \\
\text { críticos e questionadores de aprendizado; } \\
\text { - apoio prático ao desenvolvimento de abordagens } \\
\text { voltadas ao desenvolvimento e amistosas à } \\
\text { comunidade para a partilha do conhecimento, como } \\
\text { copyleft, General Public License (GPL) etc. } \\
\text { B2.2 - Uma interpretação ativa e a implementação, } \\
\text { por parte de órgãos públicos e estatais, das leis e } \\
\text { acordos nacionais e internacionais sobre copyright e } \\
\text { patentes relevantes, favorecendo uma partilha } \\
\text { equilibrada do conhecimento, ou seja: } \\
\text { - apoio para o ‘uso justo’ de material sobre } \\
\text { copyright, freqüentemente barrado por termos de } \\
\text { licenciamento não negociáveis para material digital, } \\
\text { como publicações especializadas; } \\
\text { - reconhecimento e proteção dos ‘direitos morais’ } \\
\text { dos autores; } \\
\text { - restrições sobre o gerenciamento de direitos } \\
\text { digitais, encriptação e mecanismos anti-burladores }\end{array}$ \\
\hline
\end{tabular}




\begin{tabular}{|c|c|}
\hline & $\begin{array}{l}\text { que inibam o uso justo de informação eletrônica; } \\
\text { - esforços para formatar a propriedade intelectual de } \\
\text { acordo com condições nacionais, o que } \\
\text { freqüentemente iram contra tendências nos acordos } \\
\text { internacionais; } \\
\text { - esforços para formatar a propriedade intelectual em } \\
\text { produtos digitais que promovam novos modelos de } \\
\text { negócios, baseados na partilha do conhecimento, e } \\
\text { que coíbam medidas (como o patenteamento de } \\
\text { software) que mantenham monopólios ou oligopólios } \\
\text { e inibam a inovação; } \\
\text { - esforços para assegurar que expressões de folclore } \\
\text { não sejam registradas e exploradas por terceiras } \\
\text { partes (incluindo o problema do 'autor } \\
\text { identificável’), ou seja, pela incorporação da } \\
\text { proteção folclórica na legislação nacional } \\
\text { (casos de Bolívia, 1968, e Quênia, 1975). }\end{array}$ \\
\hline $\begin{array}{l}\text { B3 - Todos os trabalhos financiados e produzidos de } \\
\text { forma pública se tornam parte do domínio público. }\end{array}$ & $\begin{array}{l}\text { B3.1 - Políticas públicas e medidas práticas para } \\
\text { assegurar que todo o conhecimento apoiado por } \\
\text { fundos públicos se torne imediatamente parte do } \\
\text { domínio público. } \\
\text { B3.2 (Ver A3.3) - O volume de informação mantida } \\
\text { por órgãos públicos deve ser colocado sob domínio } \\
\text { público. } \\
\text { B3.3 - Canais e empresas públicas devem colocar } \\
\text { seus arquivos sob domínio público. }\end{array}$ \\
\hline $\begin{array}{l}\text { B4 - Participação efetiva da sociedade } \\
\text { civil no processo de governança, inclusive em sua } \\
\text { formulação, preparação, regulação, implementação } \\
\text { e revisão, além de apoio para participação em nível } \\
\text { internacional. }\end{array}$ & $\begin{array}{l}\text { B4.1 - Um processo participativo de } \\
\text { desenvolvimento de políticas, que inclua } \\
\text { participação significativa da sociedade civil e os } \\
\text { recursos necessários para que todos os parceiros } \\
\text { dêem contribuições efetivas. } \\
\text { B4.2 - Meios ativos e dinâmicos para que } \\
\text { preocupações públicas com relação a governança e } \\
\text { políticas sejam ouvidas e atendidas. } \\
\text { B4.3 - Mecanismos permanentes para participação } \\
\text { pública na revisão e implementação de políticas em } \\
\text { curso, de modo descentralizado quando apropriado, } \\
\text { inclusive em relação aos acordos internacionais. } \\
\text { B4.4 - Mecanismos e instrumentos de auto- } \\
\text { governança, desenvolvidos e utilizados pela } \\
\text { sociedade civil, reconhecidos ou não pelo governo. }\end{array}$ \\
\hline
\end{tabular}




\begin{tabular}{|c|c|}
\hline \multicolumn{2}{|c|}{$\begin{array}{c}\text { Pilar C } \\
\text { Liberdades civis e direitos políticos na Sociedade da Informação }\end{array}$} \\
\hline Atributos do Direito à Comunicação & $\begin{array}{l}\text { Indicadores de um ambiente propício } \\
\text { para o direito à comunicação }\end{array}$ \\
\hline $\begin{array}{l}\text { C1 - Privacidade de informação e proteção de dados, } \\
\text { atendendo ao direito de saber, acessar, corrigir e } \\
\text { controlar o uso de toda informação pessoal mantida } \\
\text { em forma digital por outrem. }\end{array}$ & $\begin{array}{l}\text { C1.1 - Leis que assegurem que dados pessoais são } \\
\text { mantidos pelo mínimo período necessário, bem } \\
\text { como utilizados apenas para os propósitos } \\
\text { autorizados expressamente pela pessoa a qual se } \\
\text { referem. Isto inclui dados pessoais fornecidos a } \\
\text { serviços (saúde, finanças, compras etc.), atividades } \\
\text { de segurança pública ou privada, material de } \\
\text { vigilância em vídeo, informações inclusas em fichas } \\
\text { de identificação (em eventos ou pedidos de emprego) } \\
\text { e dados de funcionários mantidos por empregadores. } \\
\text { C1.2 - Garantia do cumprimento de tais leis de modo } \\
\text { acessível financeiramente, transparente e pró-ativo, e } \\
\text { com o direito de revisão quando direitos tiverem sido } \\
\text { violados. } \\
\text { C1.3 - Existência de uma cultura ampla e difundida } \\
\text { de autoregulação e códigos de conduta em termos de } \\
\text { privacidade e proteção de dados, entre atores da } \\
\text { sociedade civil, do governo e do setor privado. }\end{array}$ \\
\hline $\begin{array}{l}\text { C2 - O direito à privacidade na comunicação é um } \\
\text { direito humano e é essencial para o desenvolvimento } \\
\text { humano auto-determinado, em atividades tanto } \\
\text { cívicas, políticas, sociais e econômicas como } \\
\text { culturais. }\end{array}$ & $\begin{array}{l}\text { C2.1 - Leis e regulações que assegurem o direito à } \\
\text { privacidade na comunicação, seja através da internet, } \\
\text { telefonia ou outros meios eletrônicos, com exceções } \\
\text { apenas em circunstâncias extremas e claramente } \\
\text { definidas, e que valham em ambientes privados, } \\
\text { públicos e comerciais. } \\
\text { C2.2 - Garantia do cumprimento de tais leis de modo } \\
\text { transparente, não-partidário e pró-ativo, inclusive } \\
\text { contra violações praticadas pelos governos, e com o } \\
\text { direito de revisão quando direitos tiverem sido } \\
\text { violados. } \\
\text { C2.3 - Leis para controlar SPAM (mensagens } \\
\text { comerciais de correio eletrônico não solicitadas) e } \\
\text { impedi-lo de inibir a capacidade geral de interação } \\
\text { na internet. }\end{array}$ \\
\hline $\begin{array}{l}\text { C3 - Ausência de censura eletrônica. O direito de } \\
\text { transmitir informação eletrônica sem censura } \\
\text { ou controle por parte de agentes do Estado, judiciais, } \\
\text { comerciais, empregadores ou outrem. }\end{array}$ & $\begin{array}{l}\text { C3.1 - Leis de proteção contra censura na internet ou } \\
\text { outros meios de publicação eletrônica, seja através } \\
\text { de filtros, sites prescritos, sanções contra provedores } \\
\text { de acesso ou conteúdo e a responsabilização dos } \\
\text { provedores por conteúdo hospedado. } \\
\text { C3.2 - Leis ou regulações, inclusive auto-regulação } \\
\text { por parte da indústria, que inclua obrigações para } \\
\text { que operadores comerciais de publicações e difusão } \\
\text { eletrônicas (provedores de acesso, mecanismos de } \\
\text { busca, provedores de banda [infra-estrutura de } \\
\text { internet, empresa de telefonia, internet a } \\
\text { cabo ou via satélite]) ajam como operadores de rede } \\
\text { (common carriers) para material judicialmente legal. } \\
\text { C3.3 - Garantia do cumprimento de tais leis de modo } \\
\text { acessível }\end{array}$ \\
\hline
\end{tabular}




\begin{tabular}{|c|c|}
\hline & $\begin{array}{l}\text { financeiramente, transparente e pró-ativo, e com o } \\
\text { direito de revisão quando direitos tiverem sido } \\
\text { violados. }\end{array}$ \\
\hline $\begin{array}{l}\text { C4 - Liberdade de associação no meio eletrônico, } \\
\text { para participar de protestos públicos ou debates } \\
\text { online. }\end{array}$ & $\begin{array}{l}\text { C4.1 - Leis que salvaguardem contra vigilância em } \\
\text { vídeo excessiva e seu possível efeito intimidante } \\
\text { sobre a liberdade de associação. }\end{array}$ \\
\hline $\begin{array}{l}\text { C5 - Participação efetiva da sociedade civil no } \\
\text { processo de governança, incluindo sua formulação, } \\
\text { projeto, regulação, implementação e avaliação. }\end{array}$ & $\begin{array}{l}\text { C5.1 - Um processo participativo de } \\
\text { desenvolvimento de políticas, que inclua a } \\
\text { participação significativa da sociedade civil e os } \\
\text { recursos necessários para que todos os parceiros } \\
\text { dêem contribuições efetivas. } \\
\text { C5.2 - Meios ativos e dinâmicos para que } \\
\text { preocupações públicas com relação a governança e } \\
\text { políticas sejam ouvidas e atendidas. } \\
\text { C5.3 - Mecanismos permanentes para participação } \\
\text { pública na revisão e implementação de políticas em } \\
\text { curso, de modo descentralizado quando apropriado, } \\
\text { inclusive em relação aos acordos internacionais. } \\
\text { C5.4 - Mecanismos e instrumentos de auto- } \\
\text { governança, desenvolvidos e utilizados pela } \\
\text { sociedade civil, reconhecidos ou não pelo governo. } \\
\text { (ver C1.3 acima) }\end{array}$ \\
\hline
\end{tabular}




\section{Pilar D}

\section{Assegurando acesso eqüitativo e a preços razoáveis a TICs}

\begin{tabular}{|c|c|}
\hline Atributos do Direito à Comunicação & $\begin{array}{l}\text { Indicadores de um ambiente propício } \\
\text { para o direito à comunicação }\end{array}$ \\
\hline $\begin{array}{l}\text { D1 - Acesso a TICs, inclusive à telefonia, à internet } \\
\text { e a outros serviços, de modo econômico, igualitário e } \\
\text { apropriado para todo o povo e suas comunidades. }\end{array}$ & $\begin{array}{l}\text { D1.1 - Um quadro legal e regulatório que favoreça } \\
\text { fortemente a extensão de modo universal dos } \\
\text { serviços e do acesso a TICs como a prioridade para } \\
\text { este setor. } \\
\text { D1.2 - Medidas políticas, convencionais e } \\
\text { inovadoras, que vão além das abordagens } \\
\text { mercadológicas e corporativas, para incluir, por } \\
\text { exemplo, redes comunitárias, subsídios cruzados } \\
\text { efetivos por parte de usuários mais ricos com fins de } \\
\text { universalização do serviço, e assim por diante. Serão } \\
\text { então considerados: } \\
\text { - infra-estrutura fixa e telefonia; } \\
\text { - telefonia móvel, inclusive em termos de custos; } \\
\text { - telecentros comunitários; } \\
\text { - licenciamento de provedores de acesso, portais de } \\
\text { internet e medidas de apoio à internet; } \\
\text { - links de satélite Vsat e de dados. } \\
\text { D1.3 - Apoio ao desenvolvimento de indústrias } \\
\text { locais ao longo dos setores relacionados a TICs, tais } \\
\text { como incentivos específicos, períodos de transição } \\
\text { para a criação de companhias locais etc. } \\
\text { D1.4 - Estatísticas e indicadores que demonstrem } \\
\text { que o efeito cumulativo das políticas implementadas } \\
\text { está realmente reduzindo a exclusão em termos de } \\
\text { acesso, disponibilidade, acessibilidade econômica, } \\
\text { acessibilidade e uso, e na promoção do bem-estar } \\
\text { público. }\end{array}$ \\
\hline $\begin{array}{l}\text { D2 - Disponibilidade de conteúdo relevante para } \\
\text { todas as comunidades lingüísticas e grupos } \\
\text { marginalizados. }\end{array}$ & $\begin{array}{l}\text { D2.1 - Ações de apoio para produção de conteúdo } \\
\text { por e para todas as comunidades lingüísticas. } \\
\text { D2.2 - Apoio ao desenvolvimento de softwares } \\
\text { lingüísticos técnicos e interfaces de hardware. }\end{array}$ \\
\hline $\begin{array}{l}\text { D3 - Competências e habilidades que permitam ao } \\
\text { povo e a suas comunidades fazerem uso das TICs } \\
\text { para atingir seus objetivos individuais e coletivos. }\end{array}$ & $\begin{array}{l}\text { D3.1 - Apoio para desenvolvimentos de } \\
\text { competências e habilidades, como treinamentos, } \\
\text { programas de intercâmbio, módulos curriculares } \\
\text { formais etc., amplamente disponíveis em } \\
\text { estabelecimentos de ensino comuns, como escolas, } \\
\text { bibliotecas, centros comunitários etc. }\end{array}$ \\
\hline $\begin{array}{l}\text { D4 - Participação efetiva da sociedade civil no } \\
\text { processo de governança, incluindo sua formulação, } \\
\text { projeto, regulação, implementação e avaliação. }\end{array}$ & $\begin{array}{l}\text { D4.1 - Um processo participativo e multilateral de } \\
\text { desenvolvimento de estratégias, que inclua } \\
\text { participação significativa da sociedade civil e os } \\
\text { recursos necessários para que todos os participantes } \\
\text { dêem contribuições efetivas. Isto inclui infra- } \\
\text { estrutura (seja fixa, sem-fio ou outros) e serviços } \\
\text { (como telefonia, celulares, transmissão de dados e } \\
\text { internet); e a natureza da compreensão e } \\
\text { planejamento estratégicos por parte de todos. } \\
\text { D4.2 - Meios ativos e dinâmicos para que } \\
\text { preocupações públicas com relação a governança e }\end{array}$ \\
\hline
\end{tabular}




\begin{tabular}{|l|l|}
\hline & políticas sejam ouvidas e atendidas. \\
& D4.3 - Mecanismos permanentes para participação \\
& pública na revisão e implementação de políticas em \\
& curso, de modo descentralizado quando apropriado, \\
& inclusive em relação aos acordos internacionais. \\
& D4.4 - Mecanismos e instrumentos de auto- \\
& governança, desenvolvidos e utilizados pela \\
& sociedade civil, reconhecidos ou não pelo governo. \\
\hline
\end{tabular}


